\title{
UNIVERSAL JURISDICTION, THE ALIEN TORT STATUTE, AND TRANSNATIONAL PUBLIC- LAW LITIGATION AFTER KIOBEL
}

\author{
ERNEST A. YOUNG $\dagger$
}

\begin{abstract}
The Alien Tort Statute (ATS), enacted in 1789 as part of the first Judiciary Act, provides that "[t]he district courts shall have original jurisdiction of any civil action by an alien for a tort only, committed in violation of the law of nations...." Although the statute lay dormant until the 1980s, the ATS has since become the font of transnational public-law litigation in American courts. This litigation, frequently involving largely foreign parties and events, is a form of civil-side universal jurisdiction. Like more traditional forms of universal jurisdiction, the ATS allows American courts to hear human-rights claims based on the enormity of the offense, even when the claims lack any significant ties to the United States. But unlike traditional universal jurisdiction, which is overwhelmingly a criminal phenomenon, ATS suits place control over initiation and conduct of this litigation in private hands and engage the exceptional machinery of American civil justice.

The Supreme Court sharply limited ATS suits in the 2013 case of Kiobel v. Royal Dutch Petroleum Co. This Article defends the Court's rejection of universal jurisdiction in Kiobel and assesses the future of human-rights litigation in American courts. I submit that the scope of human-rights litigation under the ATS is best viewed not as a sui generis problem of foreign-relations law, as most lawyers and scholars have treated it, but instead within the more traditional federal-courts framework of implied rights of action and federal common law. Kiobel's concerns about extraterritorial application of
\end{abstract}

Copyright (C) 2015 Ernest A. Young.

$\dagger$ Alston \& Bird Professor of Law, Duke University School of Law. I am grateful to Curt Bradley for providing the original impetus for this project, to Philip Alito, Jennifer Bandy, David Chiang, Christine Couvillon, Dollar Hoang, David Hollander-Urbach, Rachel Mueller, Alison Newman, and David Riesenberg for valuable research assistance, to Lyndsey Haas, Madeleine Hogue, Daniel Rice, and the other editors of the Duke Law Journal for their careful work (and patience), and to William Dodge, as well as participants at the Fall 2009 DukeHarvard Foreign Relations Law Conference and the Spring 2014 Berkeley Public Law \& Policy Workshop for their comments on various versions of the manuscript. 
the ATS fit comfortably within this framework, and they suggest that the Court will be extremely cautious about expanding the scope of ATS litigation in future cases. I also situate the ATS within the context of broader debates about enforcement of international human rights. These debates raise two crucial questions of institutional design: reliance on supranational or national institutions, and public or private control of enforcement. This debate, too, can be usefully informed by domestic debates about regulatory enforcement.

\section{TABLE OF CONTENTS}

Introduction 1025

I. The Alien Tort Statute as Civil-Side Universal Jurisdiction ........1029

A. Universal Jurisdiction over Human-Rights Claims..........1029

1. The Bases of Jurisdiction in International Law.

2. Universal Jurisdiction in Practice 1034

3. Continuing Controversy over Universal Jurisdiction ...1041

B. The ATS and the Rise of Filártiga Suits ..........................1045

1. Originalist Takes on the ATS .......................................1045

2. The Filártiga Line ..........................................................1048

C. The Supreme Court Limits ATS Litigation: Sosa and

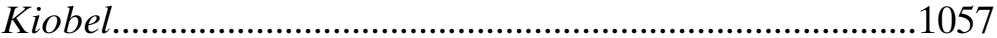

II. The Trouble with Privatized Universal Jurisdiction ....................1065

A. Filártiga Claims as Implied Rights of Action....................1069

1. The General Decline of Implied Private Rights

Under Federal Statutes and the Constitution ................1069

2. Sosa's Translation Problem and the Domestic-Law

Limits on Private Rights Under the ATS .....................1074

B. Extraterritoriality as a Constraint on Sosa's Right of Action.

1. Extraterritoriality, Jurisdiction, and Implied Rights of Action. 1080

2. Did Congress Intend to Reach Foreign-Cubed

Cases? 1083

3. Extraterritoriality as a "Special Factor Counselling

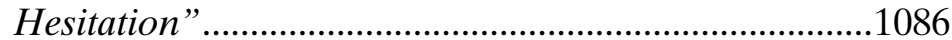

C. Universal Jurisdiction in International Perspective .........1087

1. Extraterritoriality, Universality, and International Law 1088

2. Political Control of Foreign Policy and the Leap from Criminal- to Civil-Side Universal Jurisdiction...1092

3. America's Exceptional Civil-Justice System 1096 
III. Transnational Public-Law Litigation After Kiobel.

A. U.S. Defendants and the Unresolved Pre-Kiobel

Questions.

B. The Broader Debate About Transnational Public-Law

Litigation

1. Supranational vs. National Enforcement 1113

2. Public vs. Private Enforcement.

Conclusion 1125

\section{INTRODUCTION}

Writing in 1991, Harold Koh articulated a broad vision of "transnational public law litigation" as a parallel to the domestic public-law litigation that had desegregated American schools, cleaned up prisons and mental hospitals, and reformed a broad range of other public institutions. " "Like its domestic counterpart," Dean Koh wrote, "transnational public law litigation seeks to vindicate public rights and values through judicial remedies. In both settings, parties bring 'public actions,' asking courts to declare and explicate public norms, often with the goal of provoking institutional reform." ${ }^{2}$ The centerpiece of Koh's vision was claims by victims of torture and other human-rights violations against their abusers, brought in American federal courts under the long-dormant Alien Tort Statute (ATS). The U.S. Court of Appeals for the Second Circuit's 1980 decision recognizing such a claim in Filártiga v. Peña-Irala ${ }^{3}$ was, in Koh's view, the "Brown v. Board of Education" that "inaugurated the era of transnational public law litigation in which we now live."

The ATS provides that "[t]he district courts shall have original jurisdiction of any civil action by an alien for a tort only, committed in violation of the law of nations...." Although the statute lay

1. Harold Hongju Koh, Transnational Public Law Litigation, 100 YALE L.J. 2347 (1991) [hereinafter Koh, Transnational Public Litigation]. For the domestic version, see generally Abram Chayes, The Role of the Judge in Public Law Litigation, 89 HARV. L. REV. 1281 (1976).

2. Koh, Transnational Public Litigation, supra note 1, at 2347-48.

3. Filártiga v. Peña-Irala, 630 F.2d 876, 878 (2d Cir. 1980).

4. Koh, Transnational Public Litigation, supra note 1, at 2366 (citing Brown v. Bd. of Educ., 347 U.S. 483 (1954)); see also Ingrid Wuerth, Kiobel v. Royal Dutch Petroleum Co.: The Supreme Court and the Alien Tort Statute, 107 AM. J. INT'L L. 601, 601 (2013) (observing that since Filártiga, "the ATS has garnered worldwide attention and has become the main engine for transnational human rights litigation in the United States").

5. 28 U.S.C. $\$ 1350$ (2012). This provision has been part of the judicial code since 1789. See Judiciary Act of 1789, ch. $20 \S 9$ (b), 1 Stat. 73, 77. Courts and commentators refer to $\S 1350$ as both the "ATS" and the "Alien Tort Claims Act," or "ATCA." 
dormant for much of our history, for the past thirty-five years it has been a prominent vehicle for international human-rights litigation. Initial claims focused on individual perpetrators of abuses in foreign lands, but more recent plaintiffs have sued multinational corporations alleged to have participated in such abuses. By one count, "there have been about 173 judicial opinions regarding the ATS [since Filártiga]. One hundred fifty-five ATS cases have been filed against corporations in federal courts, with about six-to-ten ATS cases being filed annually." ${ }^{6}$

The Filártiga line of cases employed the ATS as a form of civilside universal jurisdiction, offering recourse against serious violators of international law despite the absence, in many if not most cases, of any significant connection between the parties or events in issue and the United States. Jurisdiction rested not on particular U.S. connections or interests, but on a "more general obligation to help redress certain violations of international law as such, regardless of where they may have occurred or the identity of the victim." "The American human-rights community has viewed the ATS as "a badge of honor" that "contribute[s] . . to the moral and political standing of the United States as a champion of international law," defended the statute's role as a form of universal civil jurisdiction. ${ }^{9}$ Critics have worried about the potential of universal jurisdiction to undermine American foreign policy and criticized broad ATS litigation as a threat to international business. ${ }^{10}$

The Supreme Court sharply limited the ATS's role in Kiobel v. Royal Dutch Petroleum Co. ${ }^{11}$ which held that the ATS generally has no extraterritorial reach - that is, foreign nationals cannot sue foreign defendants for actions unconnected to the United States. Significant uncertainty remains, however; the Kiobel majority's analysis seemed to leave open the possibility for a significant range of human-rights

6. Donald Earl Childress III, The Alien Tort Statute, Federalism, and the Next Wave of Transnational Litigation, 100 GEO. L.J. 709, 713 (2012).

7. Anne-Marie Burley (now Slaughter), The Alien Tort Statute and the Judiciary Act of 1789: A Badge of Honor, 83 AM. J. INT'L L. 461, 464 (1989).

8. Id. at $464,493$.

9. E.g., Donald Francis Donovan \& Anthea Roberts, The Emerging Recognition of Universal Civil Jurisdiction, 100 AM. J. INT'L L. 142, 146-48 (2006).

10. See, e.g., Curtis A. Bradley, Universal Jurisdiction and U.S. Law, 2001 U. CHI. LEGAL F. 323, 325 (2001) [hereinafter Bradley, Universal Jurisdiction]; GARY CLYDE HUFBAUER \& Nicholas K. Mitrokostas, Awakening Monster: The Alien Tort Statute of 1789, at 37-43 (2003).

11. Kiobel v. Royal Dutch Petroleum Co., 133 S. Ct. 1659, 1669 (2013). 
litigation under the ATS, and various concurring opinions suggested that the universal-jurisdiction view of the statute is far from dead. This Article defends the result in Kiobel and explores the implications of its reasoning. I argue that the Court rightly situated the ATS within established federal-courts doctrines governing implied rights of action, and that these doctrines can also resolve many future questions concerning the scope of ATS claims.

Contemporary debates over the proper scope of ATS litigation reflect continuing tensions in American law and politics. ${ }^{12}$ There is, first, the perennial tension between desire to vindicate universal principles of human rights abroad and aversion to foreign entanglements. George W. Bush's proclamation that "[t]he best hope for peace in our world is the expansion of freedom in all the world,",13 for example, contrasts with John Quincy Adams's insistence that "America ... goes not abroad, in search of monsters to destroy. She is the well-wisher to the freedom and independence of all. She is the champion and vindicator only of her own." ${ }^{14}$ A related tension exists between an "ideological fervor and messianic streak" and "offsetting tendencies" toward "[p]ragmatism" and "a willingness to compromise to achieve vital goals." ${ }^{15}$ Hence, Anne-Marie Slaughter highlights a clash between narrow interpretations of the ATS based on "cramped and circumspect" views of the national interest grounded in "prudence" and broader readings grounded in "honor," "virtue," and "a vision of the United States at the forefront of efforts to strengthen the rule of law in international as well as domestic affairs."16

As it has developed in recent years, however, the ATS jurisprudence also reflects some less familiar tensions. One is between

12. See David J. Bederman, International Law Advocacy and Its Discontents, 2 CHI. J. INT'L L. 475, 477-84 (2001) (framing the ATS debate within competing ideological traditions in U.S. foreign-relations law); Wuerth, supra note 4, at 601 ("[T]o the extent the 'culture wars' have played out in U.S. foreign relations law, the ATS has been their center of gravity.").

13. President George W. Bush, Second Inaugural Address (Jan. 20, 2005), available at http://www.gutenberg.org/files/925/925-h/925-h.htm\#link2H_4_0056; see also John B. Bellinger III, Legal Advisor to the U.S. Sec'y of State, Enforcing Human Rights in U.S. Courts and Abroad: The Alien Tort Statute and Other Approaches, Address Delivered at Vanderbilt University Law School (Apr. 11, 2008), in 42 VAND. J. TRANSNAT'L L. 1, 1 (2009) ("U.S. foreign policy-under every Administration-involves promoting respect for human rights around the world.").

14. President John Quincy Adams, Speech to the U.S. House of Representatives on Foreign Policy (July 4, 1821), available at http://millercenter.org/president/speeches/detail/3484.

15. GeOrge C. Herring, From Colony to Superpower: U.S. Foreign Relations SINCE 1776 , at 5 (2008).

16. See Burley, supra note 7 , at $489,493$. 
models of international law grounded in official state practice and international institutions, on the one hand, and a more decentralized model that emphasizes the role of nongovernmental organizations (NGOs) and national courts. This divide emerged in Kiobel itself, as national governments tended to oppose broad forms of ATS litigation, while NGOs vigorously promoted them. ${ }^{17}$ A comparable tension exists on the domestic level between public enforcement of regulatory standards by government agencies and enforcement by "private attorneys general," often through common-law litigation that substitutes courts and juries for legislatures and expert agencies. ${ }^{18}$ Any effort to resolve continuing uncertainties under the ATS or to amend its provisions should take account of these broader tensions regarding the role of domestic courts in the development and enforcement of international law.

Part I of this Article describes the background of the ATS and its development into a form of civil-side universal jurisdiction. Part II shows why universal jurisdiction meshes poorly with the ATS's structure, which lacks any express private right to sue. An aggressive implied right of action in transnational human-rights cases cuts against the grain of federal-courts doctrine counseling restraint where Congress has not explicitly authorized private litigation. This tension has surfaced in recent decisions narrowing the ATS. Part III turns to ATS litigation after Kiobel; I then step back to consider ATS litigation in light of broader tensions in both domestic and international law enforcement. Any viable human-rights regime must rely significantly on national courts, and involvement by U.S. courts can further not only human rights but America's pragmatic interests as well. Achieving such a regime, however, will require careful institutional design with support and leadership from the political branches.

17. Compare, e.g., Brief of the Gov'ts of U.K. of Great Britain and the Netherlands as Amici Curiae in Support of the Respondents at 6-7, Kiobel v. Royal Dutch Petroleum Co., 132 S. Ct. 1659 (2013) (No. 10-1491) [hereinafter Great Britain \& Netherlands Brief] (filed Feb. 3, 2012) (urging the Court to reject corporate liability in ATS suits), with Brief of Amici Curiae International Human Rights Organizations and International Law Experts in Support of Petitioners at 2-4, Kiobel v. Royal Dutch Petroleum Co., 132 S. Ct. 1659 (2013) (No. 10-1491) (filed Dec. 21, 2011) (urging the opposite); see also Bellinger, supra note 13, at 14 (urging that promotion of human rights abroad be left to the professionals in the Executive branch).

18. See, e.g., Wyeth v. Levine, 555 U.S. 555, 558 (2009). 


\section{THE Alien TORT STATUTE AS CIVIL-SIDE UNIVERSAL JURISDICTION}

Judge Henry Friendly famously described the ATS as "a kind of legal Lohengrin.... [N]o one seems to know whence it came." ${ }^{19}$ Whatever its original purpose, the ATS has served in modern times primarily as a vehicle for human-rights claims brought by aliens against other aliens for human-rights violations committed outside the United States. Beth Stephens has called these "core Filártiga lawsuits, ${ }^{20}$ after the Second Circuit's seminal decision in Filártiga v. Peña-Irala ${ }^{21}$ which initiated the modern era of human-rights litigation under the ATS.

Used in this way, the ATS amounts to a uniquely American form of universal jurisdiction. The ATS, as understood in Filártiga and its progeny, opens American courts to victims of human-rights abuses whenever the perpetrators may be found within the jurisdiction of those courts, regardless of whether the relevant events have any tie to the United States. This Part traces that development. I begin with a brief overview of universal jurisdiction in international law, then turn to the story of the ATS.

\section{A. Universal Jurisdiction over Human-Rights Claims}

Debates about the ATS raise several distinct jurisdictional questions. It is helpful, at least to a point, to distinguish between a state's jurisdiction to prescribe (to apply its own law), to adjudicate (to subject a legal dispute to the state's own tribunals), and to enforce (to compel compliance with the applicable law, generally through executive action). ${ }^{22}$ An American court might assert jurisdiction to adjudicate a dispute, for instance, but apply international law as the rule of decision on the ground that the United States lacks jurisdiction to prescribe in the relevant circumstances. But these categories blur, overlap, and connect in myriad ways. For example, international law typically does not prescribe remedies for

19. IIT v. Vencap, Ltd., 519 F.2d 1001, 1015 (2d Cir. 1975). For non-opera buffs, Lohengrin was the mysterious knight in the eponymous opera by Richard Wagner.

20. Beth Stephens, Translating Filártiga: A Comparative and International Law Analysis of Domestic Remedies for International Human Rights Violations, 27 YALE J. INT'L L. 1, 12 (2002) [hereinafter Stephens, Translating Filártiga].

21. Filártiga v. Peña-Irala, 630 F.2d 876 (2d Cir. 1980).

22. See generally RESTATEMENT (THIRD) OF THE FOREIGN RELATIONS LAW OF THE UNITED STATES $§ 401$ (1987) [hereinafter RESTATEMENT (THIRD)] (distinguishing these three forms of jurisdiction). 
violations, ${ }^{23}$ yet adjudication often involves fashioning a remedy, which in turn involves elements of both prescription and enforcement. Moreover, the Legal Realists taught that the law is often at least somewhat indeterminate, so adjudicating a claim under a particular legal principle will involve a degree of lawmaking as the court applies that principle to particular cases. ${ }^{24}$ That is one reason parties care not only about what law will govern their case but also about what court will apply that law. Adjudication almost always involves some degree of prescription.

Jurisdictional questions in this area also arise under two distinct bodies of law (international and domestic), and the domestic questions concern both the federal Constitution and the relevant jurisdictional statutes. This Section deals primarily with the permissible exercise of jurisdiction under international law; I discuss some constitutional questions in passing in Part II.B. But it is worth remembering that these questions are interconnected. The statutory and constitutional provisions empowering the U.S. federal courts constrain those bodies far more than do the capacious principles found in international law, but it remains likely that international principles governing the appropriate exercise of prescriptive and adjudicatory authority shaped the vision of the judicial power reflected in Article III and the first Judiciary Act. And to add one more layer of complexity, the international law that influenced the Framers is quite different from the international law that exists today.

This Section traces the outlines of universal jurisdiction in international law and practice as a backdrop to the development of the American ATS. Three points are crucial: universal jurisdiction is unsettled and controversial in principle; its exercise is extremely rare

23. See, e.g., Eric A. Posner \& Alan O. Sykes, Efficient Breach of International Law: Optimal Remedies, "Legalized Noncompliance," and Related Issues, 110 MICH. L. REV. 243, 244 (2011) ("The topic of remedies is one of the most undeveloped areas of international law."). Efforts by international treaties and institutions to develop principles of individual remedies remain fairly embryonic. See, e.g., Liesbeth Zegveld, Remedies for Victims of Violations of International Humanitarian Law, 85 INT'L REV. RED CROSS 497, 497-98 (2003). In particular, "the concept of a private civil action in which one person sues another for violation of international law is virtually unknown to international law." William R. Casto, The New Federal Common Law of Tort Remedies for Violations of International Law, 37 RUTGERS L.J. 635, 643 (2006) [hereinafter Casto, New Federal Common Law]. For example, the United Nations Human Rights Commission's "Principles on the Right to a Remedy" "are first and foremost concerned with domestic remedies." Zegveld, supra, at 513 (emphasis added).

24. See generally Ernest A. Young, A General Defense of Erie Railroad Co. v. Tompkins, 10 J.L. ECON. \& POL'Y 17, 32, 102-05 (2013) [hereinafter Young, Erie] (explaining how courts make law by interpreting it). 
in practice; and when other countries do employ it, it is nearly always a tool of criminal (not civil) enforcement.

1. The Bases of Jurisdiction in International Law. "The startingpoint in this part of the law," according to Sir Ian Brownlie's leading treatise, is "that, at least as a presumption, jurisdiction is territorial.". Jurisdiction is generally a function of sovereignty, and sovereigntyeven in this day and age-remains grounded in territory. ${ }^{26}$ As Cherif Bassiouni has explained, "[s]overeignty, jurisdiction, and territory have traditionally been closely linked... due to the recognized importance of avoiding jurisdictional conflicts between states and providing legal consistency and predictability." ${ }^{27}$ Traditionally, extraterritorial jurisdiction was largely limited to offenses committed by a state's own nationals abroad. ${ }^{28}$ Other forms of extraterritorial jurisdiction developed in the last century: states base jurisdiction over non-nationals in cases involving actions outside their borders on a "protective principle" (preventing conduct that may cause harm within their borders) or "passive-personality principle" (redressing extraterritorial crimes committed against a state's own nationals). ${ }^{29}$ Although extraterritorial in reach, both protective and passivepersonality jurisdiction retain a link to territoriality and nationality through their emphasis on the impact of the action in question. ${ }^{30}$

25. IAN BRownlie, PRINCIPLES OF PUBliC INTERNATIONAL LAW 299 (7th ed. 2008); see also M. Cherif Bassiouni, The History of Universal Jurisdiction and Its Place in International Law [hereinafter Bassiouni, History of Universal Jurisdiction], in UNIVERSAL JURISDICTION: NATIONAL COURTS AND THE PROSECUTION OF SERIOUS CRIMES UNDER INTERNATIONAL LAW 39, 40 (Stephen Macedo ed., 2004) [hereinafter UNIVERSAL JURISDICTION] ("Throughout the course of legal history, jurisdictional powers have primarily been exercised in accordance with the principle of territorial jurisdiction.").

26. See BRownliE, supra note 25, at 301; Eugene Kontorovich, The Piracy Analogy: Modern Universal Jurisdiction's Hollow Foundation, 45 HARV. INT'L L.J. 183, 188 (2004) [hereinafter Kontorovich, Piracy Analogy] ("[C]ontrol over territory is the hallmark of sovereignty.").

27. Bassiouni, History of Universal Jurisdiction, supra note 25, at 40; see also Anne-Marie Slaughter, Defining the Limits: Universal Jurisdiction and National Courts, in UNIVERSAL JURISDICTION, supra note 25, at 168, 171-72 [hereinafter Slaughter, Universal Jurisdiction].

28. See Brownlie, supra note 25, at 303-04; Bassiouni, History of Universal Jurisdiction, supra note 25 , at 41.

29. See RESTATEMENT (THIRD), supra note 22, § 402; BROWNLIE, supra note 25, at 304-05; Louis Henkin, Gerald L. Neuman, Diane F. Orentlicher \& David W. Leebron, HuMAN RIGHTS 657 (1999); Bassiouni, History of Universal Jurisdiction, supra note 25, at 41.

30. See Bassiouni, History of Universal Jurisdiction, supra note 25, at 42. Moreover, each of these bases for jurisdiction remains subject to a general requirement of reasonableness. See RESTATEMENT (THIRD), supra note 22, § 403(1). 
Universal jurisdiction - that is, jurisdiction over "acts committed outside [states'] territory by non-nationals whose victims also were not their nationals" ${ }^{31}$-arises instead from the nature of the offense. ${ }^{32}$ Section 404 of the Restatement (Third) of American Foreign Relations Law states the common understanding in the international-law community:

A state has jurisdiction to define and prescribe punishment for certain offenses recognized by the community of nations as of universal concern, such as piracy, slave trade, attacks on or hijacking of aircraft, genocide, war crimes, and perhaps certain acts of terrorism, even where none of the bases of jurisdiction indicated in $\S 402$ is present. ${ }^{33}$

As used here, universal jurisdiction is primarily jurisdiction to adjudicate crimes defined by international law. ${ }^{34}$ It is thus important to distinguish between universal jurisdiction to adjudicate, on the one hand, and universal condemnation of certain crimes, the extraterritorial reach of national legislation, and the universal reach of international adjudicative bodies (which may or may not rely on universal jurisdiction for their authority). ${ }^{35}$

31. Henkin, Neuman, OREnTlicher \& LeEBron, supra note 29, at 657.

32. See, e.g., BROWNLIE, supra note 25 , at 305 (stating that universal jurisdiction is typically recognized where "the nature of the crime . . . justif[ies] . . repression . . as a matter of international public policy"); Máximo Langer, The Diplomacy of Universal Jurisdiction: The Political Branches and the Transnational Prosecution of International Crimes, 105 AM. J. INT'L L. 1, 1 (2011) ("The jurisdictional claim is predicated on the atrocious nature of the crime and legally based on treaties or customary international law.").

33. RestATEMENT (ThIRD), supra note 22, § 404; see also THE PRINCETON PRINCIPLES ON UNIVERSAL JURISDICTION, Principle 1.1, at 21 (2001) [hereinafter PRINCETON PRINCIPLES], available at https://lapa.princeton.edu/hosteddocs/unive_jur.pdf ("[U]niversal jurisdiction is criminal jurisdiction based solely on the nature of the crime, without regard to where the crime was committed, the nationality of the alleged or convicted perpetrator, the nationality of the victim, or any other connection to the state exercising such jurisdiction.").

34. It remains jurisdiction "to prescribe" in the sense that the state exercising universal jurisdiction must liquidate the meaning of often-amorphous concepts in treaties and CIL. This sort of lawmaking is not the same as the normative discretion enjoyed by common-law courts authorized to shape, say, rules of tort. See Young, Erie, supra note 24, at 32, 102-05.

35. See Bassiouni, History of Universal Jurisdiction, supra note 25, at 62; see also Stephan A. Oxman, Comment: The Quest for Clarity, in UNIVERSAL JURISDICTION, supra note 25, at 64. Universal jurisdiction ordinarily does require the presence of the accused, although Mr. Oxman notes a "super pure" case of universal jurisdiction "in which jurisdiction would exist even without the presence of the accused." Id.; see also A. Hays Butler, The Growing Support for Universal Jurisdiction in National Legislation, in UNIVERSAL JURISDICTION, supra note 25, at 67, 69 (describing the Belgian statute). 
Universal jurisdiction is typically justified on the ground that the "exceptional gravity" of the offense "affect[s] the fundamental interests of the international community as a whole." "36 Universalist prosecutions thus rest on a consensus of nations, reflected in customary law, as to a particular crime's extraordinary depravity. ${ }^{37}$ This is not the only account of universal jurisdiction, nor does it best fit universality's historical antecedents. But it is the account that dominates contemporary discussions of universal jurisdiction over war crimes, torture, genocide, and the like-the human-rights violations typically giving rise to ATS litigation. ${ }^{38}$

Both proponents and critics of international human-rights litigation agree that the turn to universal jurisdiction reflects the weakness of criminal-enforcement institutions at the international level. A report by Human Rights Watch argues that

despite the creation of ad hoc international criminal tribunals... vast gaps persist in the ability to bring to justice persons accused of the gravest international crimes .... Even with the advent of a permanent International Criminal Court, it is expected that there will remain an "impunity gap unless national authorities, the international community and the [ICC] work together".... [A] critical role thus remains for national courts and tribunals through the exercise of universal jurisdiction. ${ }^{39}$

Universal jurisdiction thus counts on domestic courts to enforce principles of international law. ${ }^{40}$ Serious resource and personnel

36. PRINCETON PRINCIPLES, supra note 33, Introduction, at 23; see also Slaughter, Universal Jurisdiction, supra note 27, at 169, 173 (observing that the "standard account" of universal jurisdiction aims at "crimes under international law" that are "so heinous that they strike at the 'whole of mankind' and shock 'the conscience of nations"') (quoting Attorney Gen. v. Eichmann, 36 I.L.R. 277, 280 (Isr. Sup. Ct. 1962)).

37. See Slaughter, Universal Jurisdiction, supra note 27, at 175 ("The inherent limits built into this account flow from the combination of the degree of depravity or fundamental inhumanity necessary to classify certain acts as international crimes and the necessity of agreement on that classification by a considerable majority of sovereign states.").

38. See, e.g., Nehal Bhuta \& JÜrgen Schurr, Human Rights WATCh, Universal JURISDICTION IN EUROPE: THE STATE OF THE ART 1, 34 (2006), available at http://www.hrw .org/sites/default/files/reports/ij0606web.pdf [hereinafter HUMAN RIGHTS WATCH] (advocating the assertion of universal jurisdiction over "the gravest crimes recognized by the international community"); Kontorovich, Piracy Analogy, supra note 26, at 204-07 (documenting the centrality of the "heinousness principle" to contemporary thinking about universal jurisdiction).

39. HUMAN RIGHTS WATCH, supra note 38 , at 1.

40. Slaughter, Universal Jurisdiction, supra note 27, at 168. Critics of international criminal institutions have similarly argued that international courts have had mixed results, at best, especially in the area of human rights. See generally ERIC A. POSNER, THE PERILS OF GLOBAL 
constraints limit international criminal courts' ability to deal with more than a fraction of the potential cases within their jurisdictions. ${ }^{41}$ Only domestic courts will generally enjoy the extensive remedial powers necessary to grant effective redress in human-rights cases. In many cases, domestic courts exercising universal jurisdiction afford an attractive avenue for those seeking to vindicate claims under international law.

2. Universal Jurisdiction in Practice. Three aspects of the contemporary practice of universal jurisdiction are critical for present purposes. First, universal jurisdiction as practiced by other countries is always criminal in character. ${ }^{42}$ The Princeton Principles on Universal Jurisdiction, for example, explicitly state that "universal jurisdiction is criminal jurisdiction." ${ }^{43}$ Domestic legislation implementing the "prosecute or extradite" provisions of the postwar human-rights conventions was framed in criminal terms. ${ }^{44}$ Likewise, the later wave of domestic statutes implementing the Rome Statute of the International Criminal Court (ICC)—which imposes a duty on "every State to exercise its criminal jurisdiction over those responsible for international crimes" ${ }^{45}$-also involved criminal, not civil, sanctions. ${ }^{46}$ The aspiration of these treaties and domestic statutes

LEGALISM 150-74 (2009); Stephanos Bibas \& William W. Burke-White, International Idealism Meets Domestic-Criminal-Procedure Realism, 59 DUKE L.J. 637, 639-41 (2010).

41. See Bibas \& Burke-White, supra note 40, at 676-77 (describing how limited funding constrains international courts); HUMAN RIGHTS WATCH, supra note 38, at 1 ("With finite resources, international courts and mixed 'internationalized' tribunals can try only a relatively small number of perpetrators, and the courts' mandates are generally limited to crimes committed in specific territories and conflicts.").

42. William Dodge has suggested that the distinction between civil and criminal jurisdiction is irrelevant to the legality of universal jurisdiction under international law. E-mail from William Dodge to Ernest Young (Apr. 23, 2014) (on file with author). My point in this article, however, is that domestic law frequently does make this distinction important, and that the distinction has important functional consequences that both foreign-relations law and international law must take into account.

43. PRINCETON PRINCIPLes, supra note 33, Principle 1.1, at 28. The Restatement (Third) does state-presumably with the ATS in mind-that "jurisdiction on the basis of universal interests has been exercised in the form of criminal law, but international law does not preclude the application of non-criminal law on this basis, for example, by providing a remedy in tort or restitution for victims of piracy." RESTATEMENT (THIRD), supra note 22, § $404 \mathrm{cmt}$. b.

44. See Butler, supra note 35, at 68.

45. Rome Statute of the International Criminal Court, 37 I.L.M. 999, pmbl. (1998).

46. See Butler, supra note 35, at 68-72. See generally Loi relative à la répression des violations graves du droit international humanitaire [Act Concerning the Punishment of Serious Violations of International Humanitarian Law] of Feb. 10, 1999, MONITEUR BELGE [M.B.] [Official Gazette of Belgium], Mar. 23, 1999, reprinted at 38 I.L.M. 918 (Belgium); R.S.C. 2000, 
has been to establish "a system of international criminal justice ... in which both international criminal tribunals and national courts have an important and mutually reinforcing role to play in the enforcement of international criminal norms." ${ }^{47}$

Several of the European universal-jurisdiction statutes did incorporate elements that Americans associate with civil justice, such as an initiating role for victims and some compensatory remedies. Victims of persecution initiated the case against former Chilean dictator Augusto Pinochet in Spain, for example, and Iraqi families initiated Belgium's abortive case against various U.S. officials arising out of the Iraq War. ${ }^{48}$ Some European civil-law countries recognize the action civile, which allows a civil claim for compensation to be attached to a criminal proceeding. ${ }^{49}$ Nonetheless, the criminal nature of the suit, with public control of the proceedings, remains primary; under the civil law's inquisitorial model, for instance, the judge will control the investigation and exercise prosecutorial discretion even when private victims initiate the lawsuit. ${ }^{50}$ Moreover, these civil-side features have been among the most controversial aspects of universal jurisdiction in other countries, with statutory reforms frequently curtailing or eliminating them. ${ }^{51}$

The second general point is that "the exercise of pure universal jurisdiction is actually very rare. ${ }^{, 52}$ International treaties do not authorize universal jurisdiction as broadly as one might infer from the proposition that universality is appropriate to punish the gravest international crimes. ${ }^{53}$ A number of the broad human-rights conventions proposed and ratified after World War II, such as the

c. 24, available at http://laws.justice.gc.ca/en (Canada); International Criminal Court Act 2001, c. 17, available at http://www.hmso.gov.uk/acts/acts2001/20010017.htm (United Kingdom). For an account of the British and Belgian experiences, see Langer, supra note 32, at 15-19 (Britain), 26-32 (Belgium).

47. Butler, supra note 35 , at 76 .

48. See Langer, supra note 32, at 29 (discussing the Belgian case); Richard J. Wilson, Prosecuting Pinochet in Spain, 6 HUM. RTS. BRIEF 3, 3 (1999).

49. See generally Donovan \& Roberts, supra note 9, at 154 (collecting provisions).

50. See, e.g., Langer, supra note 32 , at 36 (describing the Pinochet proceedings).

51. See infra text accompanying note 71 .

52. Slaughter, Universal Jurisdiction, supra note 27, at 168-69.

53. See, e.g., Henry A. Kissinger, The Pitfalls of Universal Jurisdiction, FOREIGN AFF., July/Aug. 2001, at 87 ("[N]one of these steps"-including "the Universal Declaration of Human Rights of 1948, the genocide convention of 1948 . . the antitorture convention of 1988 " or the human-rights provisions of the "Final Act of the Conference on Security and Cooperation in Europe"- "was conceived at the time as instituting a 'universal jurisdiction."”). 
1984 Torture Convention, ${ }^{54}$ required states to criminalize the relevant conduct in their domestic law and to prosecute or extradite persons accused of such conduct. Absent extradition, prosecution by state parties would often rely on universal jurisdiction, ${ }^{55}$ and many countries adopted laws providing for universal jurisdiction over such crimes. ${ }^{56}$ Some of these domestic laws were tied to particular humanrights conventions, ${ }^{57}$ others provided for domestic jurisdiction not only over specific international crimes but also over "any other offense which under international treaties or conventions, should be prosecuted" in the forum country ${ }^{58}$ However, universal jurisdiction is conspicuously absent from some of the more important human-rights conventions; neither the Geneva Conventions on war crimes nor the Genocide Conventions, for example, explicitly provide for it despite the widespread contention that war crimes and genocide are universal offenses. ${ }^{59}$ Although universal jurisdiction over these crimes is now

54. See Convention Against Torture and Other Cruel, Inhuman, or Degrading Treatment or Punishment, Art. 7(1), G.A. Res. 39/46, U.N. GAOR 39th Sess., Supp. No. 51, U.N. Doc. A/39/51 (1984), entered into force June 26, 1987, draft reprinted in 23 I.L.J. 1027 (1985) ("The State Party in the territory under whose jurisdiction a person alleged to have committed any offence referred to in article 4 is found shall in the cases contemplated in article 5, if it does not extradite him, submit the case to its competent authorities for the purpose of prosecution.").

55. See Bassiouni, History of Universal Jurisdiction, supra note 25, at 55 (distinguishing between "extradite or prosecute" provisions and pure universal jurisdiction, but conceding that absent extradition, any prosecution of persons without national or territorial links to the forum state must rely on universal jurisdiction); see also Lori F. Damrosch, Comment: Connecting the Threads in the Fabric of International Law, in UNIVERSAL JURISDICTION, supra note 25, at 94 ("[A]t a minimum all the prosecute-or-extradite crimes are ones as to which there is an option to exercise jurisdiction without any link to the crime other than custody of the offender.").

56. See Butler, supra note 35, at 68; Mark Chadwick, Modern Developments in Universal Jurisdiction: Addressing Impunity in Tibet and Beyond, 9 INT'L CRIM. L. REV. 359, 362-64 (2009).

57. See, e.g., Geneva Conventions Act, 1957, 5 \& 6 Eliz. 2, c. 52 (United Kingdom).

58. See, e.g., Amendments to the Law on Judicial Power art. 23.4 (B.O.E. 1/2009) (Spain) (amending Organic Law on the Judiciary art. 23.4 (B.O.E. 6/1985)). On the Spanish experience, see Langer, supra note 32, at 32-41.

59. Compare, e.g., RESTATEMENT (THIRD), supra note 22, § 404 (asserting that universal jurisdiction extends to genocide and war crimes), with Bassiouni, History of Universal Jurisdiction, supra note 25, at 51 (noting that "[n]o convention dealing with the law of armed conflict contains a specific provision on universal jurisdiction," and "customary international law as reflected by the practice of states does not, in the judgment of this writer, mean that universal jurisdiction has been applied in national prosecutions"); id. at 53 (noting that the Genocide Convention makes no provision for universal jurisdiction); see also Madeline $\mathrm{H}$. Morris, Universal Jurisdiction in a Divided World: Conference Remarks, 35 NEW ENG. L. REV. 337, 347 (2001) (noting that "[u]niversal jurisdiction over genocide was proposed but rejected during the negotiation of the Genocide Convention, in view of strong opposition by France, the Soviet Union, and the United States"). 
widely thought to be part of CIL, "[t]he origin and basis of this development ... are actually questionable." ${ }^{60}$

More important, nations simply do not exercise universal jurisdiction when they have it. ${ }^{61}$ For example, David Scheffer, the U.S. Ambassador-at-Large for War Crimes, reported in 2000 that "governments [are] almost universally determined not to use the universal jurisdiction tools they have to prosecute." ${ }^{62}$ This is true both at present and historically. Allied prosecutions of Nazi war criminals after World War II, although sometimes viewed as instances of universal jurisdiction, were grounded firmly in national jurisdiction and the rights of the victor states as participants in the conflict. ${ }^{63}$ Spain's famous effort to prosecute Augusto Pinochet, which Human Rights Watch described as a "wake up call" demonstrating the potential of universal jurisdiction, ${ }^{64}$ relied partially on universal jurisdiction but also on injuries to Spanish nationals. ${ }^{65}$ More generally,

60. Morris, supra note 59, at 347; see also infra notes 68-82 and accompanying text.

61. See HumAn Rights WATCH, supra note 38 , at 2 ("On paper, a great many countries around the world appear to recognize that they can and should exercise universal jurisdiction over international crimes such as torture and war crimes, by passing laws that permit the prosecution of such crimes. But practice has generally lagged far behind laws on the books."); Slaughter, Universal Jurisdiction, supra note 27, at 170 ("[A]t least at this stage in the evolution of universal jurisdiction,... although the basis for jurisdiction over war criminals and perpetrators of genocide and crimes against humanity has been established in many countries, the actual prosecutions have been blocked in many cases.").

62. David Scheffer, Opening Address, Universal Jurisdiction Conference, Dec. 2000, in 35 NEw ENG. L. REV. 233, 234 (2001); see also Bassiouni, History of Universal Jurisdiction, supra note 25, at 62 ("The tendency of state practice has been not to apply [universal jurisdiction].").

63. Gary J. Bass, The Adolf Eichmann Case: Universal and National Jurisdiction, in UNIVERSAL JURISDICTION, supra note 25, at 77, 81-83; Bassiouni, History of Universal Jurisdiction, supra note 25, at 51-52; Morris, supra note 59, at 341-45; see also Bass, supra, at 83 (noting that "the focus of the Nuremberg prosecution of top Nazi leaders was aggressive war," not violations of human rights). Israel's famous prosecution of Adolf Eichmann, following his abduction from Argentina, was in large part for crimes against the Jewish people-not simply for crimes against humanity generally. See Bass, supra, at 85; Slaughter, Universal Jurisdiction, supra note 27, at 172 (noting that "the Eichmann prosecution relied on both passive personality and the protective principle in addition to universality").

64. See The Pinochet Precedent: How Victims Can Pursue Human Rights Criminals Abroad, HUMAN RIGHTS WATCH (Nov. 1, 1998), http://www.hrw.org/legacy/campaigns/chile98/ precedent.htm; see also Amnesty International USA, Universal Jurisdiction: Questions and Answers, available at http://www.amnestyusa.org/counter-terror-with-justice/reports-statementsand-issue-briefs/universal-jurisdiction/page.do?id=1108003 (last visited Feb. 4, 2015) ("The Pinochet case, is the most well known case where states have exercised universal jurisdiction.").

65. See, e.g., Naomi Roht-Arriaza, The Pinochet Precedent and Universal Jurisdiction, 35 NEW ENG. L. ReV. 311, 314-15 (2001) (noting that prosecutions of Pinochet in Spain and Belgium emphasized crimes against citizens and residents of the respective forum states); Wilson, supra note 48 , at 3. 
a 2003 study by one of the the ICC's architects found that "increasing numbers of states are enacting laws that provide for universal jurisdiction," but "it has not yet been supported by the practice of states. In fact, there are only a few cases known to scholars in which pure universal jurisdiction... has been applied." ${ }^{, 66}$ A more recent survey found that, out of " 1051 complaints or cases considered by public authorities" in European nations with universal-jurisdiction statutes, "only 32 have actually been brought to trial."

It is worth emphasizing, moreover, that universalist prosecutions have been confined to a handful of states in Western Europe ${ }^{68}$ hence, it is difficult to say that universal jurisdiction is part of CIL. ${ }^{69}$ Certainly, American law lacks any examples of classical universalist criminal prosecutions. ${ }^{70}$ Countries like Belgium and Spain that had led the way with broad assertions of universal jurisdiction appear to have

66. Bassiouni, History of Universal Jurisdiction, supra note 25, at 62 ; see also Stephen Macedo, Introduction, in UNIVERSAL JURISDICTION, supra note 25, at 8 ("[U]niversal jurisdiction is not as well established in international law as some human rights organizations and others have claimed."); Slaughter, Universal Jurisdiction, supra note 27, at 172 (noting that "many national courts have purported to exercise universal jurisdiction while actually requiring some kind of more traditional nexus to nationality or territory").

67. Langer, supra note 32 , at 7.

68. See HUMAN RIGHTS WATCH, supra note 38, at 4 ("[A] handful of EU member states have been at the center of developments in the exercise of universal jurisdiction.").

69. See also John B. Bellinger III \& William J. Haynes II, A US Government Response to the International Committee of the Red Cross Study, Customary International Humanitarian Law, 89 INT'L REV. RED CROSS 443, 465-71 (2007) (refuting, on behalf of the U.S. State Department, assertions that universal jurisdiction is supported by the practice of nations or by adequate opinio juris); Sienho Yee, Universal Jurisdiction: Concept, Logic, and Reality, 10 CHINESE J. INT'L L. 503, 529-30 (2011) (denying that universal jurisdiction has become part of international custom outside the context of piracy). Some states have argued that CIL "authorizes, or at least does not prohibit, the exercise of universal jurisdiction over the core international crimes." Langer, supra note 32, at 4. There is, of course, quite a difference between "authorizes" and "does not prohibit." And, as Langer ably demonstrates, there is no consistent or uniform practice of states exercising universal jurisdiction, even among those Western European states that have experimented with it. See id. An argument for universal jurisdiction under CIL would thus have to emphasize evidence of opinio juris over the actual practice of nations. See generally J. Patrick Kelly, The Twilight of Customary International Law, 40 VA. J. INT'L L. 449, 470 (2000) (criticizing this tendency in contemporary invocations of CIL); Bruno Simma \& Philip Alston, The Sources of Human Rights Law: Custom, Jus Cogens, and General Principles, 12 AUSTL. Y.B. INT'L L. 82, 89 (1992) (same).

70. The federal piracy statute is the best example of American adoption of universal jurisdiction. But as Professor Bassiouni points out, virtually all the Marshall Court's cases under the piracy statute involved American nationals. Bassiouni, History of Universal Jurisdiction, supra note 25, at 279 n.55. Recent opinions applying the piracy statute have invoked universal jurisdiction, but the cases involved attacks on U.S. nationals. See, e.g., United States v. Shibin, 722 F.3d 233, 236, 239-40 (4th Cir. 2013) (attack on German and American vessels); United States v. Dire, 680 F.3d 446, 449, 469 (4th Cir. 2012) (attack on a U.S. navy vessel). 
beaten significant retreats. Belgium, for example, famously entertained an effort by Iraqi families to prosecute former highranking U.S. officials involved in the Gulf War, including President George H.W. Bush, Vice President Dick Cheney, Secretary of State Colin Powell, and General Norman Schwarzkopf. But when American officials suggested that NATO's headquarters could be withdrawn from Brussels, amendments that drastically narrowed the Belgian statute followed in short order. ${ }^{71}$

The third striking feature of universal jurisdiction in actual practice is that it tends to diverge from the standard account resting on the "heinousness" of the underlying offense. Historically, universal jurisdiction was limited largely to piracy, which continues to provide the paradigm case of legitimate universal jurisdiction. ${ }^{72}$ Eugene Kontorovich has persuasively argued, however, that piracy is not a particularly outrageous offense in comparison to other crimes. ${ }^{73}$ After all, virtually every state once employed its own privateers (basically, licensed pirates) without any sense that their actions were morally outrageous, and the law treated piracy as simply robbery occurring on the high seas. ${ }^{74}$ The best rationale for universal jurisdiction over piracy, while not always articulated, seems to have rested on the statelessness of the perpetrators or perhaps on the difficulty of laying hold of them. ${ }^{75}$ There was, on the other hand, generally no recognition of universal jurisdiction over genocide or war crimes even though

71. See Ratner, Belgium's War Crimes Statute: A Postmortem, 97 AM. J. INT’L L. 888, 89091 (2003). For Spain's amendment of its universal-jurisdiction statute to cut back on aggressive prosecutions, see Langer, supra note 32, at 32-41.

72. See, e.g., Bassiouni, History of Universal Jurisdiction, supra note 25, at 47-49; see also United States v. Klintock, 18 U.S. (5 Wheat.) 144, 152 (1820) (stating that pirates "are proper objects for the penal code of all nations").

73. Kontorovich, Piracy Analogy, supra note 26, at 186; see also M. Cherif Bassiouni, International Crimes: Jus Cogens and Obligatio Erga Omnes, 59 LAW \& CONTEMP. PROBS. 63, 70 (1996) (acknowledging that piracy "neither threatens peace and security nor shocks the conscience of humanity, though it may have at one time").

74. See Kontorovich, Piracy Analogy, supra note 26, at 210-29.

75. See, e.g., 4 William Blackstone, COMMENTARIES ON THE LAWS OF ENGLAND 71 (1769) (emphasizing that the pirate had placed himself back in the state of nature vis-à-vis victims and prosecuting states); Samuel Shnider, Universal Jurisdiction over "Operation of a Pirate Ship": The Legality of the Evolving Piracy Definition in Regional Prosecutions, 38 N.C. J. INT'L L. \& COM. REG. 473, 491 (2013) (suggesting that piracy is "a crime that could only be addressed by interstate cooperation, and that by its nature, location, and effects defines a shared interest that can be applied with minimal disruption of the world order"); Expert Declaration of Madeline Morris at 14-15, Sarei v. Rio Tinto PLC, 221 F. Supp. 2d. 1116 (C.D. Cal. 2009) (No. 00-11695) (noting that pirates "preyed upon the nationals, vessels, and commerce of all states, but came within the jurisdiction of none"). 
those crimes were recognized offenses centuries before Nuremberg. ${ }^{76}$ The idea that universal jurisdiction follows whenever a crime is universally thought to be awful is thus a very new development. ${ }^{77}$

A similar disconnect exists with respect to current practice concerning other crimes. Universal condemnation is neither a sufficient nor a necessary condition for universal jurisdiction. The international conventions dealing with war crimes and genocide lack any specific provision for universal jurisdiction, and whether that jurisdiction may be inferred is controversial ${ }^{78}$ on the other hand, international conventions tend to call for signatories to exercise universal jurisdiction most frequently in cases of less serious crimes, such as narcotics offenses or destruction of cultural property. ${ }^{79}$ Equally important, Máximo Langer has demonstrated that states do not decide to exercise universal jurisdiction simply as a function of the enormity of the offense; rather, prosecutions reflect a weighing of costs and benefits by political-branch officials in the prosecuting state. ${ }^{80}$ These incentives "tend to favor [assertion of universal jurisdiction] over low-cost defendants-those who can impose little or no international relations, political, economic, or other costs on potential prosecuting states-and especially over those low-cost defendants about whom the international community has reached

76. See Kontorovich, Piracy Analogy, supra note 26, at 227-28.

77. Piracy is also a poor precedent for modern universal jurisdiction because it was defined to exclude official actions on behalf of governments. See, e.g., Morris, supra note 59, at 339-40 ("By excluding state acts from the definition of piracy, the law of piracy was designed to prevent universal jurisdiction over piracy from becoming a source of interstate conflict.").

78. See Langer, supra note 32, at 4. For diverging views, compare Universal Jurisdiction over War Crimes, INT'L COMM. OF THE RED CROSS (Oct. 31, 2013), https://www.icrc.org/en/ document/universal-jurisdiction-over-war-crimes-factsheet ("While the Conventions do not expressly state that jurisdiction is to be asserted regardless of the place of the offence, they have generally been interpreted as providing for mandatory universal jurisdiction."), with Yee, supra note 69, at 511-19 (arguing that the major human-rights conventions do not authorize universal jurisdiction).

79. See Bassiouni, History of Universal Jurisdiction, supra note 25, at 56-61.

80. Langer, supra note 32 , at 3-10. This gap between availability of universal jurisdiction and actual prosecutions is equally pronounced for piracy. See generally Eugene Kontorovich \& Steven Art, An Empirical Examination of Universal Jurisdiction for Piracy, 104 AM. J. INT'L L. 436, 452 (2010) (concluding that "under normal circumstances, nations use universal jurisdiction against a tiny fraction of high seas piracies"). The overwhelming majority of U.S. prosecutions for piracy have involved attacks on American citizens. See Bassiouni, History of Universal Jurisdiction, supra note 25 , at 279 n.55. Jurisdiction would thus have rested on the passivepersonality principle rather than the universal condemnation of piracy. 
broad agreement." ${ }^{\text {"1 }}$ As Eugene Kontorovich has concluded, "The endorsement by nations of universal jurisdiction as an international legal norm seems almost entirely unrelated to their willingness to put it into practice." ${ }^{82}$

\section{Continuing Controversy over Universal Jurisdiction.} Traditional theories of jurisdiction were means of allocating sovereignty and minimizing conflict among states. Universal jurisdiction, by contrast, reflects the more general shift in international law from regulating relations among states to regulating states' treatment of their own citizens and other individuals within their control. It is avowedly reformist. As the authors of the Princeton Principles on Universal Jurisdiction affirm, "impunity for the commission of serious crimes must yield to accountability"; hence, universal jurisdiction "holds out the promise of greater justice." ${ }^{\text {}}$ Universal jurisdiction is thus a "potent weapon" that "would cast all the world's courts as a net to catch alleged perpetrators of serious crimes under international law. It holds the promise of a system of global accountability_-justice without borders-administered by the competent courts of all nations on behalf of humankind." ${ }^{84}$

But notwithstanding frequent assertions that universal jurisdiction is now well accepted, ${ }^{85}$ scholars lament that "[t]he doctrine ... has evolved ... through a process that has been less circumspect and deliberate than we might have hoped." ${ }^{, 86}$ Often the academic literature has leaped ahead of realities on the ground; as

81. Langer, supra note 32, at 5. By “agreement," Professor Langer means agreement on the culpability of the defendants and the desirability of prosecution, not the seriousness of the alleged crime. See id. at 9 (stressing the lack of protest by the accused's state of nationality).

82. Eugene Kontorovich, Measuring International Law Through Piracy, INST. LETTER, 8 (Fall 2012), https://www.ias.edu/files/pdfs/publications/letter-2012-fall.pdf.

83. PRINCETON PRINCIPLES, Introduction, supra note 33, at 23-24.

84. Macedo, supra note 66 , at 4 .

85. See, e.g., 1 JeAn-MARIE Henckaerts \& LOUISE DosWALD-BECK, INTERnAtional COMMITTEE OF THE RED CROSS, CUSTOMARY INTERNATIONAL HUMANITARIAN LAW 604 (2005) (asserting that "[s]tate practice establishes . . a as a norm of customary international law" that "[s]tates have the right to vest universal jurisdiction in their national courts over war crimes"); Supplemental Brief of Yale Law School Center for Global Legal Challenges as Amicus Curiae in Support of Petitioners, Kiobel v. Royal Dutch Petroleum Co., 132 S. Ct. 1659 (2013) (No. 10-1491), available at http://sblog.s3.amazonaws.com/wp-content/uploads/ 2012/06/10-1491-tsacsb-Yale-Law-School-Center-for-Global-Legal-Challenges.pdf (arguing unequivocally that, aside from substantive principles like sovereign immunity, international law imposes no restrictions on universal jurisdiction to adjudicate international-law offenses).

86. Morris, supra note 59, at 351-52. 
Professor Bassiouni recognizes, "The writings of scholars have driven the recognition of the theory of universal jurisdiction for serious international crimes and have offered new interpretations of CIL, albeit without much support in the law and practice of states." ${ }^{87}$ Even advocates admit that "the jurisprudence of universal jurisdiction is disparate, disjointed, and poorly understood."

I have already discussed the disconnect between the historical precedent of universal jurisdiction over piracy and the contemporary grounding of universalist prosecutions in the heinousness of the offense. $^{89}$ Other controversies concern whether universalist prosecutions rest on international or national $\operatorname{law}^{90}$ and whether the accused must be present within the prosecuting jurisdiction. ${ }^{91}$ And the broader notion of national-court intervention in the affairs of other nations has engendered significant controversy. As George Fletcher has observed, "many are outraged by Belgian, Canadian, German, and other claims to have the right to judge crimes no matter where they are committed." ${ }^{92}$

Criticism comes from three main quarters. The first includes American scholars and public officials, often-but not always-of a nationalist bent, who are concerned about the impact of universal jurisdiction on international relations. Henry Kissinger argued that universal jurisdiction is potentially unfair to defendants, may undermine emerging democracies' efforts at national reconciliation, and risks arbitrary use by national authorities to pursue their own political or ideological agendas. ${ }^{93}$ Similarly, Curtis Bradley has worried that "prosecution of foreign citizens under this concept-

87. Bassiouni, History of Universal Jurisdiction, supra note 25 , at 62 ; see also Macedo, supra note 66 , at 8 ("[U]niversal jurisdiction is not as well established in international law as some human rights organizations and others have claimed.").

88. PRINCETON PRINCIPLES, Introduction, supra note 33, at 24; see also Arrest Warrant of 11 Apr. 2000 (Dem. Rep. Congo v. Belg.), 2002 I.C.J. 3, II 44 (Feb. 14) (dissenting opinion of Judge Van Den Wyngaert) ("There is no generally accepted definition of universal jurisdiction in conventional or customary international law.").

89. See supra text accompanying notes 72-77.

90. Slaughter, Universal Jurisdiction, supra note 27, at 179-81.

91. See, e.g., Matthias Goldmann, Arrest Warrant Case (Democratic Republic of the Congo v. Belgium), in MAX PlAnCK ENCYCLOPEDia OF PUBlic InTERnATIONAL LAW, Jan. 2009, available at http://opil.ouplaw.com/view/10.1093/law:epil/9780199231690/law-9780199231690e1249?rskey=klJi44\&result=6\&q=\&prd=EPIL (discussing the International Court of Justice's (ICJ's) conflicting opinions on this issue in the Arrest Warrant case).

92. George P. Fletcher, Against Universal Jurisdiction, 1 J. INT'L CRIM. JusT. 580, 580 (2003).

93. See Kissinger, supra note 53, at 90-92. 
especially foreign leaders-will undermine peaceful international relations." "94 These concerns have echoed in numerous briefs filed by Republican administrations in ATS cases. ${ }^{95}$

More opposition comes from foreign states, many of them in the developing world, that find themselves frequent targets of universalist prosecutions. States of the African Union have been especially outspoken against the exercise of universal jurisdiction, particularly by former colonial powers in Western Europe. Following a Belgian court's issuance of an arrest warrant for the incumbent minister for foreign affairs of the Democratic Republic of the Congo (DRC), Abdoulaye Yerodia Ndombasi, the DRC sued Belgium in the International Court of Justice (ICJ) alleging, inter alia, that Belgium's assertion of universal jurisdiction violated the DRC's sovereignty. ${ }^{96}$ This incident and others ultimately led the African Union Assembly to adopt several decisions condemning the use of universal jurisdiction as "judicial overreach.",

A third criticism comes from criminal lawyers worried about the rights of the accused. Professor Fletcher, for example, has argued that universal jurisdiction's rhetoric of "prevent[ing] gaps" in the criminal law and ending impunity reverses the traditional priorities of Western domestic criminal law, subordinating the rights of the accused to the interests of victims and the state. ${ }^{98} \mathrm{He}$ also contends that universal jurisdiction creates the possibility of multiple prosecutions, thereby

94. Bradley, Universal Jurisdiction, supra note 10, at 325; see also Morris, supra note 59, at 354 (anticipating that universal jurisdiction "will become a source and an instrument of interstate conflict").

95. See Jide Nzelibe, Contesting Adjudication: The Partisan Divide over Alien Tort Statute Litigation, 33 NW. J. INT'L L. \& BUS. 475, 504-17 (2013); see also BROWNLIE, supra note 25, at 305 (concluding that "Anglo-American opinion is hostile to the general principle involved [in universal jurisdiction]").

96. See Arrest Warrant of 11 Apr. 2000 (Dem. Rep. Congo v. Belg.), 2002 I.C.J. 3, II 44 (Feb. 14); Goldmann, supra note 91, at IIT 15-18 (noting that although the DRC prevailed on immunity grounds and the ICJ did not rule on the universal-jurisdiction point, dueling supplemental opinions revealed the depth of disagreement on the court as to the legitimacy of universal jurisdiction).

97. See, e.g., Assembly of the African Union (AU), Decision on the Report of the Commission on the Abuse of the Principle of Universal Jurisdiction, Decision No. Assembly/AU/Dec.199 (XI), AU Doc. Assembly/AU/14 (XI), 30 June-1 July 2008, x 5 and xx ii and iii; see also Harmen van der Wilt, Universal Jurisdiction Under Attack: An Assessment of African Misgivings Towards International Criminal Justice as Administered by Western States, 9 J. INT'L CRIM. JUST. 1043, 1044 (2011); Karinne Coombes, Universal Jurisdiction: A Means to End Impunity or a Threat to Friendly International Relations?, 43 GEO. WASH. INT'L L. REV. 419, 441-43 (2011).

98. Fletcher, supra note 92, at 581-82. 
raising double-jeopardy problems. ${ }^{99}$ And my colleague Madeline Morris has pointed out that because "[u]niversal jurisdiction empowers the courts of all states to exercise jurisdiction over the relevant crimes," those "[j]udicial systems that are corrupt, abusive or lawless are empowered equally with others"; such jurisdiction thus raises due-process problems because it "extends extraterritorially the powers of non-independent or otherwise flawed judiciaries."

I lack space here to comprehensively catalog, much less assess, these arguments about universal jurisdiction. My point is simply to demonstrate that there is no consensus about universal jurisdiction's legitimacy-even among academics, much less in the real world. The more sober advocates of universal jurisdiction are hardly blind to these concerns. Cherif Bassiouni, for example, has recognized that "[e]ven with the best of intentions, universal jurisdiction can be used imprudently, creating unnecessary frictions between states, potential abuses of legal processes, and undue harassment of individuals prosecuted or pursued for prosecution under this theory." ${ }^{101}$ Likewise, Anne-Marie Slaughter acknowledges "the common-sense intuition that universal jurisdiction is a potentially fearsome power that should only be exercised in extraordinary circumstances." 102 These advocates thus accept that "[s]urely universal jurisdiction cannot be exercised whenever the international community recognizes that the territorial state will be unlikely or unable to prosecute." ${ }^{103}$

The hard question, of course, is whether some of universal jurisdiction's laudable goals may be achieved while minimizing its risks. As Kenneth Anderson put it, "universal jurisdiction for certain

99. Id. at 582-83. One might argue that multiple prosecutions should be permitted by analogy to the "dual sovereignty" exception to domestic double-jeopardy principles. See, e.g., Westfall v. United States, 274 U.S. 256, 258 (1927) (Holmes, J.). It is far from clear, however, that this exception should apply to prosecutions by different nations for the same international crime. After all, the exception "turns on whether the two [prosecuting] entities draw their authority to punish the offender from distinct sources of power." Heath v. Alabama, 474 U.S. 82,88 (1985). Both nations would be prosecuting a breach of the same international norm. Nonetheless, the American cases do not generally differentiate between the source of law that makes the act illegal and the law that empowers the government to prosecute. See, e.g., United States v. Wheeler, 453 U.S. 313, 316-26 (1978). Those sources of law diverge when national authorities prosecute an international crime, complicating any answer to the double-jeopardy problem based on American analogies.

100. Morris, supra note 59, at 352, 354.

101. M. Cherif Bassiouni, Universal Jurisdiction for International Crimes: Historical Perspectives and Contemporary Practice, 42 VA. J. INT'L L. 81, 82 (2001).

102. Slaughter, Universal Jurisdiction, supra note 27, at 175.

103. Id. at 183 . 
truly awful things is not truly in dispute, [but] there is no getting around the internal drive of schemes of universal jurisdiction to become a one-way ratchet of expansion." ${ }^{104}$ The United States has not generally gone in for the sort of universal jurisdiction provided forand occasionally practiced-in Western Europe. We have, however, developed our own uniquely American practice of universal jurisdiction under the ATS, ${ }^{105}$ and the tendency toward expansion noted by Professor Anderson has had a powerful influence on that statute. The next two sections discuss how that came about, and how the Supreme Court more recently has sought to impose some limits.

\section{B. The ATS and the Rise of Filártiga Suits}

Congress enacted the ATS in 1789 as part of the first Judiciary Act, which established the federal judicial system. We know relatively little about the intent behind the Act's provision for federal jurisdiction over a "civil action by an alien for a tort only, committed in violation of the law of nations," prior to 1980. As Chief Justice Roberts observed in Kiobel, "the ATS was invoked twice in the late 18th century, but then only once more over the next 167 years. ${ }^{107}$ Things have become considerably more interesting, however, in the last three and a half decades.

1. Originalist Takes on the ATS. The original understanding of the ATS has proven elusive. Curtis Bradley has argued, for example, that the ATS may well have been intended simply to implement Article III's alienage jurisdiction. ${ }^{108}$ Although the 1789 Judiciary Act

104. Kenneth Anderson, Kiobel v. Royal Dutch Petroleum: The Alien Tort Statute's Jurisdictional Universalism in Retreat, 2012-2013 CATO SUP. CT. REV. 149, 154 (2013). But see Morris, supra note 59, at 361 (asking "whether in practice, a regime of universal jurisdiction will do more good or more harm overall").

105. See Kontorovich, Piracy Analogy, supra note 26, at 201 ("[U]nlike other nations, the United States has confined [universal jurisdiction] to civil litigation.”).

106. 28 U.S.C. $\S 1350$.

107. Kiobel v. Royal Dutch Petroleum Co., 133 S. Ct. 1659, 1663 (2013) (citing Moxon v. The Fanny, 17 F. Cas. 942 (No. 9895) (D. Pa. 1793); Bolchos v. Darrel, 3 F. Fas. 810 (No. 1607) (D.S.C. 1795); O'Reilly de Camara v. Brooke, 209 U.S. 45 (1908); Khedival Line, S.A.E. v. Seafarers' Int'l Union, 278 F.2d 49 (2d Cir. 1960) (per curiam)).

108. Curtis A. Bradley, The Alien Tort Statute and Article III, 42 VA. J. INT'L L. 587, 591 (2002) [hereinafter Bradley, ATS]; see also Arthur M. Weisburd, The Executive Branch and International Law, 41 VAND. L. REV. 1205, 1223-26 (1988). Article III's alienage jurisdiction extends to "Controversies . . . between a State, or the Citizens thereof, and foreign States, Citizens or Subjects." U.S. CONST. art. III, § 2, cl. 1. For a critique of the alienage interpretation, see generally, e.g., William S. Dodge, The Constitutionality of the Alien Tort Statute: Some 
contained a general provision for suits involving aliens, it covered only cases in which at least $\$ 500$ was in controversy. ${ }^{109}$ The ATS, on Professor Bradley's account, would have allowed the United States to honor its international-law obligation to provide redress for alien tort claimants-most of whom could not have met the $\$ 500$ threshold under the Judiciary Act's general alienage provisions ${ }^{110}$ - without opening the federal courts generally to most British creditors' claims for debt against American citizens. ${ }^{111}$ By contrast, the United States would have had no international-law obligation to provide a forum for suits between aliens, especially for controversies arising elsewhere. ${ }^{112}$

Other lawyers and scholars have advanced interpretations that ground the ATS in Article III's provision for jurisdiction over cases "arising under" federal law. ${ }^{113}$ The Reagan Justice Department, for example, took a "denial of justice" position that the ATS was designed to provide a remedy to foreigners in situations where failing to do so would breach the nation's duty to another nation. ${ }^{114}$ On this

Observations on Text and Context, 42 VA. J. INT'L L. 687 (2002) [hereinafter Dodge, Text and Context] (raising textual and historical objections to Bradley's argument); Burley, supra note 7, at 469 ("[I]t is implausible that the primary purpose of the Alien Tort Statute was to avert the denial of justice to aliens. The broad sweep of this explanation simply does not fit with the precise and narrow wording of the Statute.").

109. See Judiciary Act of 1789 , ch. $20, \S 11,1$ Stat. 73, 78.

110. See Bradley, ATS, supra note 108, at 625-26; William R. Casto, The Federal Courts' Protective Jurisdiction over Torts Committed in Violation of the Law of Nations, 18 CONN. L. REV. 467, 497 n.168 (1986) [hereinafter Casto, Protective Jurisdiction].

111. Bradley, ATS, supra note 108, at 625-26. As Dean Slaughter notes, however, British creditors' claims were the category of claims in which the state courts were most notoriously denying justice to foreigners; hence, their exclusion from the ATS would have vitiated any effort to use that statute to ensure compliance with the United States' international-law obligations. Burley, supra note 7, at 467-68.

112. See Bradley, ATS, supra note 108, at 630 (citing Vattel and Blackstone).

113. But see id. at 597-619 (offering extensive historical evidence that the law of nations did not fall within the original understanding of the "Laws of the United States" as used in Article III).

114. Brief for the U.S. as Amicus Curiae at 15, Trajano v. Marcos, 978 F.2d. 493 (D. Haw. 1986) (No. 86-0297) (arguing that the history of the ATS "indicates that the Statute's scope is limited to torts (amounting to violations of either a treaty or the law of nations) committed by citizens of the United States or other persons subject to its jurisdiction, under circumstances in which the United States might be held accountable to the offended nation"); see also Kenneth C. Randall, Federal Jurisdiction Over International Law Claims: Inquiries into the Alien Tort Statute, 18 N.Y.U. J. INT'L L. \& POL. 1, 20-21, 60-61 (1985) (agreeing that the ATS was enacted primarily to prevent denials of justice to aliens injured within the United States, but arguing that the language of the statute sweeps more broadly to cover extraterritorial human-rights suits by aliens against other aliens). 
view, the ATS was meant to prevent international breaches that might plunge the young nation into war. More recently, A.J. Bellia and Bradford Clark advanced a variant of this position, arguing that "the ATS was originally enacted to enable the United States to remedy a specific, but important, law of nations violation-the intentional infliction of harm by a US citizen upon the person or personal property of an alien." nations and, if not redressed by the perpetrator's nation, gave the victim's nation just cause for war." ${ }^{, 16}$ In their view, then, "the ATS is best understood as a self-executing, fail-safe measure that enabled the United States to avoid responsibility for law of nations violations" by providing redress in its own courts. ${ }^{117}$

Anne-Marie Slaughter, on the other hand, understands the ATS "as fulfilling a more general duty under the law of nations," that is, "to uphold the law of nations as a moral imperative-a matter of national honor." ${ }^{118}$ On this view, the framers of the Judiciary Act used the ATS as a step toward affirming the validity of international law and securing the young nation's place in the international legal system. The framers' notion was not entirely altruistic, Dean Slaughter notes, because "a system in which all states were virtuous would be a much better place for the United States." ${ }^{, 19}$ William Dodge has similarly argued that "the original intent of the Alien Tort Clause was to provide [a] broad civil remedy for violations of the law of nations," and that the ATS's framers anticipated that the content

115. Anthony J. Bellia, Jr. \& Bradford R. Clark, The Alien Tort Statute and the Law of Nations, 78 U. CHI. L. REV. 445, 452 (2011) [hereinafter Bellia \& Clark, Law of Nations]; see also Anthony J. Bellia, Jr. \& Bradford R. Clark, Two Myths About the Alien Tort Statute, 18 Notre DAME L. REV. 1609, 1609 (2014) [hereinafter Bellia \& Clark, Two Myths].

116. Bellia \& Clark, Law of Nations, supra note 115, at 454.

117. Id. Tom Lee's argument that the ATS was meant to provide redress for violations of "safe conducts" has similar implications. See Thomas H. Lee, The Safe-Conduct Theory of the Alien Tort Statute, 106 Colum. L. REV. 830 (2006) [hereinafter Lee, Safe Conduct]. Professor Lee recovers a broad historical understanding of safe conducts, including not only explicit documents such as passports but also the implicit obligation to protect all friendly and neutral aliens within a nation's territory or territory it controls. See id. at 836-37. He thus concludes that the ATS provides "redress of torts against aliens that the United States had a commitment under international law to protect." Id. at 907.

118. Burley, supra note 7, at 482, 488.

119. Id. at 486 . 
of the international-law norms to be vindicated would evolve over time. $^{120}$

In the end, Dean Slaughter may be right that "definitive proof of the intended purpose and scope of the Alien Tort Statute is impossible." 121 It is hard not to agree with Judge Pierre Leval, however, that contemporary use of the ATS as a vehicle for suits against multinational corporations over events occurring in foreign lands is a "historical accident." 122 In any event, lawyers must determine what the ATS means in a world much changed from 1789. The relevant changes include an international law that now governs not only relations between states but also a state's treatment of its own citizens. ${ }^{123}$ That treatment-that is, a state's violation of its citizens' basic human rights - took center stage in the revival of ATS litigation beginning in 1980 .

2. The Filártiga Line. Joelito Filártiga was the seventeen-yearold son of Dr. Joel Filártiga, a Paraguayan physician and opponent of the military dictatorship of Alfredo Stroessner. In 1976, a Paraguayan police officer named Américo Norberto Peña-Irala tortured Joelito to death in retaliation for his father's political activities. Two years later, Joelito's sister Dolly came to the United States on a visitor's visa and sought political asylum. She soon discovered that Peña-Irala had also entered the United States and was living in Brooklyn. Dolly and her

120. William S. Dodge, The Historical Origins of the Alien Tort Statute: A Response to the “Originalists”, 19 HASTINGS INT'L \& COMP. L. REV. 221, 237, 241-43 (1996) [hereinafter Dodge, Historical Origins]; see also Dodge, Text and Context, supra note 108, at 701-11.

121. Burley, supra note 7, at 463.

122. Pierre N. Leval, The Long Arm of International Law: Giving Victims of Human Rights Abuses Their Day in Court, ForEIGN AFF., Mar./Apr. 2013, at 16, 20; see also Anderson, supra note 104, at 151-52 (observing that "the ahistorical construction [exemplified by Filártiga] could not purport to explain ... why Congress in 1789 would ever have enacted the ATS").

123. Compare, e.g., RESTATEMENT (THIRD), supra note 22, Introductory Note (observing that " $[\mathrm{t}]$ he contemporary international law of human rights . . reflects general acceptance... that how a state treats individual human beings, including its own citizens . . . is not the state's own business alone... but is a matter of international concern and a proper subject for regulation by international law" and acknowledging that this principle "has developed largely since the Second World War"), and Burley, supra note 7, at 490 (describing this development as "[t]he cornerstone of 20th-century human rights law"), with MARK W. JANIS, AN INTRODUCTION TO INTERNATIONAL LAW 245 (2d ed. 1993) (observing that before World War II, "it was thought to be antithetical for there to be international legal rights that individuals could assert against states, especially against their own governments"). 
father sued Peña-Irala for Joelito's torture and death, filing suit under the ATS in the Eastern District of New York. ${ }^{124}$

The facts of the Filartiga litigation are paradigmatic of the first wave of modern human-rights litigation under the ATS. All relevant actors were foreign nationals: Joelito Filártiga, the torture victim; his father and sister, who brought the lawsuit as plaintiffs; and PeñaIrala, the defendant. ${ }^{125}$ The events in question-Filártiga's torture at the hands of Paraguayan security personnel in retaliation for his family's political opposition to the government-occurred in Paraguay without any significant effect within the United States. The American courts' jurisdiction over the case arose solely because the defendant happened to have moved, later in life, to New York City. ${ }^{126}$

Doctrinally, Filártiga made two crucial moves. First, it held that ATS suits brought to vindicate principles of CIL fell within Article III's "arising under" jurisdiction because "the law of nations ... has always been part of the federal common law."127 And second, Filártiga held that federal courts may apply CIL without awaiting statutory incorporation of customary norms by Congress, notwithstanding Article I's express delegation to Congress of authority to "define and Punish Offences... against the Law of Nations." 128 The Filártigas were thus able to proceed with their claims under the ATS and, on remand, won a judgment of over $\$ 10$ million. ${ }^{129}$

The Second Circuit decided Filártiga against a backdrop of expanded human-rights advocacy in both the public and private sectors. The Carter administration had made promotion of human rights a centerpiece of its foreign policy in the 1970 s. ${ }^{130}$ When humanrights treaties and legislation stalled in Congress, the administration turned to the courts; hence, it filed an important amicus brief in the

124. See Filártiga v. Peña-Irala, 630 F.2d 876, 878-79 (2d Cir. 1980); Stephens, Translating Filártiga, supra note 20 , at 6.

125. Filártiga, 630 F.2d at 878-80.

126. See id.

127. Id. at 885; see Julian $\mathrm{Ku} \&$ John Yoo, Beyond Formalism in Foreign Affairs: $A$ Functional Approach to the Alien Tort Statute, 2004 SUP. CT. REV. 153, 156-57.

128. Filártiga, 630 F.2d at 886-87 (quoting U.S. CONST. art. I, § 8, cl. 10); Ku \& Yoo, supra note 127 , at 157 .

129. Filártiga v. Peña-Irala, 577 F. Supp. 860, 864-67 (E.D.N.Y. 1984). This judgment was never actually collected, however, as Peña-Irala was deported while Filártiga's appeal was still pending. See Harold Hongju Koh, Filártiga v. Peña-Irala: Judicial Internalization into Domestic Law of the Customary International Law Norm Against Torture, in INTERNATIONAL LAW STORIES 45, 60 (John E. Noyes, Laura A. Dickinson \& Mark W. Janis eds., 2007).

130. See, e.g., HERRING, supra note 15 , at 833-34. 
Second Circuit supporting the Filártigas' claim. ${ }^{131}$ This push from the Executive coincided with the development of a strong human-rights advocacy network of public-interest groups, legal academics, politicians, and journalists. ${ }^{132}$ These developments encouraged courts to take on a more aggressive role in human-rights enforcement.

The American Law Institute (ALI) published a "Tentative Draft" of its Restatement (Third) of U.S. Foreign Relations Law in 1980 - the same year as Filártiga - and that draft endorsed both aspects of the Second Circuit's decision. ${ }^{133}$ Although each aspect of Filártiga would prove controversial by the late 1990s, that decision reflected a broad consensus among international-law scholars about the domestic status of the law of nations. Louis Henkin summarized the prevailing view as follows:

$[T]$ here is now general agreement that international law, as incorporated into domestic law in the United States, is federal, not state law; that cases arising under international law are 'cases arising under... the Laws of the United States' and therefore are within the judicial power of the United States under article III of the Constitution; that principles of international law as incorporated in the law of the United States are "Laws of the United States" and supreme under article VI; that international law, therefore, is to be determined independently by the federal courts, and ultimately by the United States Supreme Court, with its determination binding on the state courts; and that a determination of international law by a state court is a federal question subject to review by the Supreme Court. ${ }^{134}$

131. See Memorandum for the United States as Amicus Curiae, Filártiga v. Peña-Irala, 630 F.2d 876 (2d Cir. 1980) (No. 79-6090); Nzelibe, supra note 95, at 495-99 (discussing the political background of the Carter administration's decision to support ATS litigation).

132. See Nzelibe, supra note 95, at 499.

133. See Restatement (ThIRD) OF THE Foreign RElations LAW OF THE United STATES (Tentative Draft No. 1, 1980), pt. I, ch. 2 introductory note at 41 (asserting that CIL "has come to be regarded as federal common law"). The final version, published in 1987, put the point even more strongly. See RESTATEMENT (THIRD), supra note 22, § $111 \mathrm{n} .3$ ("[T]he modern view is that customary international law in the United States is federal law and its determination by the federal courts is binding on the State courts."); id. $\S 111$ n.4 ("Matters arising under customary international law also arise under 'the laws of the United States,' since international law is 'part of our law' . . and is federal law." (quoting The Paquete Habana, 175 U.S. 677, 700 (1900))); RESTATEMENT (THIRD) $§ 703$ n.7 (citing Filártiga with approval with respect to individual remedies for CIL violations).

134. Louis Henkin, International Law as Law in the United States, 82 MICH. L. REV. 1555, 1559-60 (1984). 
On the other hand, many scholars of foreign-relations law-that is, the domestic law governing the interaction of the U.S. legal system with international actors-rejected this consensus. ${ }^{135}$ They pointed out that the Restatement relied on cases that did not address the domestic status of CIL, and that the ALI's pronouncement simply reflected the views of prominent international-law scholars. ${ }^{136}$ For a time, however, those scholars' views would prove highly influential.

Filártiga "gave . . . new life" to proposals by "leading international legal scholars [who] advocated the use of domestic courts to incorporate international law into domestic law." 137 And it caught on with international human-rights advocates in the courts. Over the next two decades, "[f]ederal courts ... assumed jurisdiction over cases between aliens alleging abuses such as genocide, war crimes, summary execution, disappearance, and arbitrary detention, as well as torture." ${ }^{138}$ Because the defendants were generally persons without substantial financial assets, like Peña-Irala, plaintiffs recovered little in the way of damages ${ }^{139}$ however, human-rights advocates saw vindication of their legal claims as worth the expense

135. For a critique of the Restatement's authority on these points, see Curtis A. Bradley \& Jack L. Goldsmith, Customary International Law as Federal Common Law: A Critique of the Modern Position, 110 HARV. L. REV. 815, 834-37 (1997) [hereinafter Bradley \& Goldsmith, Critique]; see also sources cited infra note 165.

136. See Bradley \& Goldsmith, Critique, supra note 135, at 834-36. The Restatement cited only two decisions in favor of its rule: Banco Nacional de Cuba v. Sabbatino, 376 U.S. 398 (1964), and Chisholm v. Georgia, 2 U.S. (2 Dall.) 419 (1793). See RESTATEMENT (THIRD), supra note $22, \S 111$, Reporters' Note 3. Sabbatino was a case about the act-of-state doctrine and refused to apply CIL; as I have explained elsewhere, Sabbatino does not support the notion that CIL is federal common law. See Ernest A. Young, Sorting Out the Debate over Customary International Law, 42 VA. J. INT'L L. 365, 438-45 (2002) [hereinafter Young, CIL]. Chisholm concerned state sovereign immunity; it involved neither foreign parties nor international law, and it was promptly overruled by the Eleventh Amendment. It would be a considerable understatement to say that the Restatement had "weak" precedential support. See also sources cited infra note 165 .

137. Ku \& Yoo, supra note 127, at 157 (citing Richard Lillich, The Proper Role of Domestic Courts in the International Legal Order, 11 VA. J. INT'L L. 9 (1970); RICHARD FALK, THE ROLE of Domestic Courts IN THE INTERNATIONAL LEgAL ORDER (1964)); see also Paul B. Stephan, Courts, the Constitution, and Customary International Law: The Intellectual Origins of the Restatement (Third) of the Foreign Relations Law of the United States, 44 VA. J. INT'L L. 33, 47 (2003) (recognizing that Filártiga triggered a "revolution in U.S. foreign relations law").

138. Stephens, Translating Filártiga, supra note 20, at 7 (citing Kadic v. Karadžić, 70 F.3d 232 (2d Cir. 1995); Abebe-Jira v. Negewo, 72 F.3d 844 (11th Cir. 1996); Trajano v. Marcos, 978 F.2d 493 (9th Cir. 1992); Xuncax v. Gramajo, 886 F. Supp. 162 (D. Mass. 1995); Forti v. SuarezMason, 672 F. Supp. 1531 (N.D. Cal. 1987)).

139. See, e.g., Philip A. Scarborough, Note, Rules of Decision for Issues Arising Under the Alien Tort Statute, 107 COLUM. L. REV. 457, 460 n.16 (2007) (noting that "[m]ost individual ATS defendants are judgment proof-either as a matter of law or as a matter of fact"). 
of litigation in many instances. ${ }^{140}$ These early cases were relatively uncontroversial, as they tended to involve "individual foreigners affiliated with governments no longer in power or viewed with disfavor by the U.S. government., ${ }^{141}$

Beginning in the late 1990s, however, the human-rights bar developed a more promising approach that focused on multinational corporations rather than present and former officials of foreign governments. The seminal case was Kadic v. Karadžic, ${ }^{142}$ which involved claims by Croat and Muslim citizens of Bosnia-Herzegovina against the leader of the Bosnian Serbs, alleging rape, torture, and genocide. Mr. Karadžić argued that he was a private actor and therefore not bound by norms of international law. ${ }^{143}$ The Second Circuit rejected this argument on two grounds: first, some international-law norms-such as those prohibiting piracy and genocide-extend to nonstate actors; ${ }^{144}$ and second, private persons may be held liable for acting in concert with state actors to violate international law. ${ }^{145}$ These holdings-particularly the latter, which supported aiding-and-abetting liability for private actors-opened the door to ATS suits against multinational corporations that could be connected to human-rights violations abroad. ${ }^{146}$

140. See, e.g., Chimene I. Keitner, Conceptualizing Complicity in Alien Tort Cases, 60 HASTINGS L.J. 61, 64 n.11 (2008) (“ATS judgments against individual defendants provide invaluable symbolic vindication.”); Koh, Transnational Public Litigation, supra note 1, at 2368 ("Although no Filártiga-type plaintiff has apparently collected full compensation for his injuries, many have expressed satisfaction simply to have won default judgments announcing that the defendant had transgressed universally recognized norms of international law."). Some plaintiffs were able to extract significant damages awards from former dictators like Ferdinand Marcos, who had fled to the United States, but collection has generally remained extremely difficult. See, e.g., Robert A. Swift, A Human Rights Class Action in the Philippines, THE PHILADELPHIA LAWYER, Winter 2012, at 37, 40, available at http://www.philadelphiabar.org/WebObjects/ PBAReadOnly.woa/Contents/WebServerResources/CMSResources/TPL.winter12_philipines .pdf (describing the difficulty of collecting and distributing to plaintiff class members $\$ 10$ million of a nearly $\$ 2$ billion judgment against Marcos's estate).

141. Beth Stephens, Upsetting Checks and Balances: The Bush Administration's Efforts to Limit Human Rights Litigation, 17 HARV. HUM. RTS. J. 169, 177 (2004) [hereinafter Stephens, Checks and Balances].

142. Kadic v. Karadžić, 70 F.3d 232 (2d Cir. 1995).

143. See id. at 239. This argument cited the lack of a recognized Bosnian Serb state, although Karadžić also claimed to be President of the self-proclaimed Republic of Srpska. See id.

144. Id. at 241-43.

145. Id. at 245; see also Stephens, Checks and Balances, supra note 141, at 176-77.

146. See, e.g., HufBAUER \& Mitrokostas, supra note 10, at 5. 
Suits against multinational corporations offered far better prospects for meaningful financial recovery than the first wave of Filártiga suits ${ }^{147}$ and they avoided many of the jurisdictional, immunity, and act-of-state doctrine hurdles associated with suing governments and their officials. ${ }^{148} \mathrm{~A}$ recent survey reports that, "[a]s of late 2006, approximately half of the post-Sosa reported ATS decisions involved corporate defendants." ${ }^{\text {149 }}$ Most of these corporations were alleged to have aided and abetted human-rights violations rather than to have committed those violations directly. ${ }^{150}$

Doe v. Unocal Corp. ${ }^{151}$ is a good example of this "second wave" of ATS litigation. Unocal, an American company based in California, became involved in a project to build an oil pipeline across Burma. The plaintiffs, Burmese villagers from a rural area through which the pipeline was to run, alleged that they had been forced to work on the pipeline and subjected to murder, rape, and torture. ${ }^{152}$ Agents of the Burmese military government had allegedly committed the atrocities, but the plaintiffs claimed that Unocal had employed the military to provide security for the pipeline project and assisted the military while knowing that it was using forced labor and committing other abuses. ${ }^{153}$ A panel of the Ninth Circuit held that Unocal could be held liable for forced labor without any showing of state action and that it could also be sued for aiding and abetting if it provided "knowing practical assistance or encouragement that ha[d] a substantial effect on the perpetration of the crime." ${ }^{154}$

Unocal involved an American defendant, but many second-wave ATS suits featured foreign plaintiffs, foreign events, and foreign defendants. For example, in Presbyterian Church of Sudan $v$.

147. See Hufbauer \& Mitrokostas, supra note 10, at 7 (stating that, as of 2003, "more than 50 MNCs [were] in the dock; and the damages claimed exceed[ed] \$200 billion”).

148. See id. at 5; Childress, supra note 6, at 723-24.

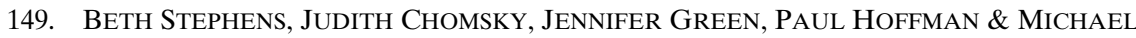
RATNER, INTERNATIONAL HUMAN RIGHTS LiTIGATION IN U.S. COURTS 23 (2d ed. 2008).

150. See, e.g., Keitner, supra note 140, at 62-63.

151. Doe v. Unocal Corp., 395 F.3d 932 (9th Cir. 2002), vacated and reh'g en banc granted, 395 F.3d 978 (2003), appeal dismissed, 403 F.3d 708 (2005).

152. Id. at 939 .

153. Id. at $937-42$.

154. Id. at 946-47. The Ninth Circuit later vacated that decision when it agreed to rehear the case en banc, and Unocal ultimately agreed to a settlement. See Rachel Chambers, The Unocal Settlement: Implications for the Developing Law on Corporate Complicity in Human Rights Abuses, 13 HuM. RTS. BRIEF 13, 14, 15 (2005). 
Talisman Energy, Inc., ${ }^{155}$ Sudanese citizens alleging human-rights abuses by the Sudanese Government sued a Canadian oil company for aiding and abetting those abuses. Similarly, in Kiobel v. Royal Dutch Petroleum, ${ }^{156}$ Nigerian citizens sued Dutch, British, and Nigerian oil companies for aiding and abetting Nigerian military forces who carried out torture, extrajudicial killing, and crimes against humanity. These suits, in which all parties are foreign and the events in question took place overseas, are called "foreign cubed" cases. ${ }^{157}$

Filártiga and other "first wave" ATS suits had likewise been foreign-cubed cases, but objections to such suits were pursued more aggressively by second-wave corporate defendants. ${ }^{158}$ By implicating large multinational corporations with substantial litigation budgets, the second wave of ATS litigation pulled in sophisticated defense counsel. ${ }^{159}$ Second-wave suits also intensified political opposition by "mobiliz[ing] domestic business constituencies that had remained relatively agnostic when ATS litigation started in the early-1980s." ${ }^{160}$ Foreign states likewise intervened in defense of their own multinational corporations by filing amicus briefs opposing broad theories of ATS liability. ${ }^{161}$ Around the same time, the advent of the War on Terror shifted the foreign-policy spotlight to security concerns. ATS litigation threatened to complicate antiterror cooperation with foreign governments and also raised the specter of suits against U.S. officials. ${ }^{162}$ Not surprisingly, the George W. Bush administration filed a series of briefs urging federal courts to radically narrow the scope of ATS suits. ${ }^{163}$

155. Presbyterian Church of Sudan v. Talisman Energy, Inc., 582 F.3d 244 (2d Cir. 2009).

156. Kiobel v. Royal Dutch Petroleum Co., 621 F.3d 111 (2d Cir. 2010).

157. See also Childress, supra note 6, at 720-21 n.84 (collecting other foreign-cubed ATS suits). Foreign-cubed suits were also an issue under the federal securities laws, but the Court seems to have largely eliminated them. See Morrison v. Nat'l Austl. Bank Ltd., 561 U.S. 247 (2010).

158. See Childress, supra note 6, at 718-19 (suggesting that defendants in first-wave suits, who tended to be present or former government officials, focused on personal-jurisdiction and official-immunity defenses).

159. In Kiobel itself, for example, Royal Dutch Petroleum was represented in the Supreme Court by Kathleen Sullivan, former dean of the Stanford Law School and a partner at the leading litigation firm of Quinn Emanuel Urquhart \& Sullivan, LLP.

160. Nzelibe, supra note 95 , at 510 .

161. See id. For a recent example, see Great Britain \& Netherlands Brief, supra note 17.

162. See Nzelibe, supra note 95, at 508-09.

163. See id. at 511-12; e.g., Reply Brief for the U.S. as Respondent Supporting Petitioner, Sosa v. Alvarez-Machain, 542 U.S. 692 (2004) (No. 03-339), 2004 WL 577654. 
Each wave of Filártiga claims provoked controversy on both jurisprudential and functional grounds. The jurisprudential objection arose from most ATS claims' reliance on CIL rather than on treaties ratified by the United States. Patrick Kelly and other internationallaw scholars attacked the coherence of CIL itself, arguing that modern customary norms are largely indeterminate and not grounded in the actual practice of nations. ${ }^{164}$ More prominently, a group of scholars led by Curtis Bradley and Jack Goldsmith challenged the conventional wisdom that CIL has the status of federal law within the domestic legal system. ${ }^{165}$ There was thus no "federal question" in Filártiga suits, and in the absence of some form of party-based jurisdiction, ${ }^{166}$ asserting federal subject-matter jurisdiction over them under the ATS would violate Article III. ${ }^{167}$

The jurisprudential objection to CIL-based litigation ran beyond jurisdiction, moreover. Plaintiffs' claims in ATS litigation generally relied on principles that appear in multilateral treaties, but that could

164. See J. Patrick Kelly, The Twilight of Customary International Law, 40 VA. J. INT'L L. 449 (2000); Simma \& Alston, supra note 69, at 82; see also Emily Kadens \& Ernest A. Young, How Customary is Customary International Law?, 54 WM. \& MARY L. REV. 885 (2013) (arguing that the link between practice and customary law has always been problematic); Eugene Kontorovich, Implementing Sosa v. Alvarez-Machain: What Piracy Reveals About the Limits of the Alien Tort Statute, 80 Notre DAME L. REV. 111, 155-61 (2004) (arguing that modern human-rights claims resting on CIL are not analogous to the sorts of CIL offenses recognized by the ATS's framers).

165. Compare Restatement (THIRD), supra note 22, § 111 Reporters' Note 3 ("[T]he modern view is that customary international law in the United States is federal law and its determination by the federal courts is binding on the State courts."), with Bradley \& Goldsmith, Critique, supra note 135 (rejecting the Restatement view as unconstitutional). For earlier denials that CIL is federal law, see Philip R. Trimble, A Revisionist View of Customary International Law, 33 UCLA L. REV. 665, 669-70 (1986); Weisburd, supra note 108, at 1239-40. Many international-law scholars, of course, have hotly disputed this view. See, e.g., Harold Hongju Koh, Is International Law Really State Law?, 111 HARV. L. REV. 1824 (1998) [hereinafter Koh, State Law]; Gerald L. Neuman, Sense and Nonsense About Customary International Law: A Response to Professors Bradley and Goldsmith, 66 FORDHAM L. REV. 371 (1997). For a general survey and assessment of the debate, see Young, CIL, supra note 136; Daniel J. Meltzer, Customary International Law, Foreign Affairs, and Federal Common Law, 42 VA. J. INT'L L. 513 (2002).

166. Article III independently confers subject-matter jurisdiction for suits "affecting" ambassadors, as well as for suits between a U.S. citizen and a foreign citizen or state. U.S. CONST. art. III, § 2. But Filártiga suits generally involve foreigners suing foreigners.

167. See Curtis A. Bradley \& Jack L. Goldsmith, III, The Current Illegitimacy of International Human Rights Litigation, 66 FORDHAM L. REV. 320, 357 (1997) [hereinafter Bradley \& Goldsmith, Current Illegitimacy]; Curtis A. Bradley \& Jack L. Goldsmith, Pinochet and International Human Rights Litigation, 97 MICH. L. REV. 2129, 2167 (1999) [hereinafter Bradley \& Goldsmith, Pinochet); see also Childress, supra note 6, at 719-20 (discussing the impact of Bradley and Goldsmith's scholarship). 
not be invoked directly because the United States had either failed to ratify those treaties or ratified them subject to reservations, understandings, and declarations forbidding their invocation in domestic litigation. ${ }^{168}$ Plaintiffs argued, however, that the treaties had somehow become part of international custom; hence, "this treatyderived CIL can be applied as domestic law in human rights cases even though the treaties themselves cannot be applied domestically." 169 ATS suits thus represented an end run around the political branches' control of the domestic incorporation of international law. ${ }^{170}$

Functional objections to Filártiga suits began with their potential to undermine U.S. foreign policy. John Bellinger, speaking as the legal adviser to the State Department during the George W. Bush administration, argued that "the ATS has given rise to friction, sometimes considerable, in our relations with foreign governments, who understandably object to their officials or their domestic corporations being subjected to U.S. jurisdiction for activities taking place in foreign countries and having nothing to do with the United States." ${ }^{171}$ And Julian $\mathrm{Ku}$ and John Yoo insisted that, as a matter of comparative institutional competence, "[f]ederal courts suffer from many institutional shortcomings, especially when compared to the executive branch, in achieving national goals in foreign relations."

Moreover, as ATS litigation shifted from foreign official defendants to multinational corporations, second-wave suits aroused traditional business objections to "strike suits" against "deep pocket" corporations. ${ }^{173}$ Nor are the potential costs limited to the corporate targets themselves. According to one study, widespread ATS

168. Bradley \& Goldsmith, Pinochet, supra note 167, at 2167-68; see also Louis Henkin, U.S. Ratification of Human Rights Conventions: The Ghost of Senator Bricker, 89 AM. J. INT'L L. 341, 344 (1995).

169. Bradley \& Goldsmith, Pinochet, supra note 167, at 2168; see also Richard B. Lillich, The Constitution and International Human Rights, 83 AM. J. INT'L L. 851, 855-57 (1989) (applauding this circumvention of limits on treaties' domestic effect).

170. See Bradley \& Goldsmith, Pinochet, supra note 167, at 2168 ("[I]t seems illegitimate for federal courts to apply as domestic law a CIL of human rights based almost exclusively on human rights treaties that the political branches have taken pains to ensure do not apply as domestic law.").

171. Bellinger, supra note 13 , at 2; see also Bradley \& Goldsmith, Pinochet, supra note 167 , at 2181.

172. Ku \& Yoo, supra note 127 , at 220.

173. See, e.g., Bill Reinsch, The Alien Tort Statute's Impact on the Business Community, WORLD COMMERCE REV., June 2012, at 28-30, available at http://www.worldcommerce review.com/publications/article_pdf/612. 
litigation may depress U.S. exports, cost tens of thousands of jobs, and discourage foreign investment both abroad and in this country. ${ }^{174}$

In light of these concerns and their aggressive presentation by well-financed defense counsel, it is unsurprising that plaintiffs have obtained few judgments in second-wave cases. ${ }^{175}$ But the small number of plaintiffs' judgments masks the significance of these suits. Defendants risk significant litigation expense and potentially embarrassing public disclosures about corporate activities abroad. ${ }^{176}$ These realities have enabled plaintiffs to obtain settlements in some significant cases, including Unocal. ${ }^{177}$ And even unsuccessful claims may bolster a political strategy aimed at curbing human-rights abuses. ${ }^{178}$ Indeed, the mere threat of suit may alter corporate behavior.

Both first- and second-wave ATS suits thus assumed an importance that transcends the still-relatively-meager results obtained by plaintiffs. And as ATS litigation expanded to draw in major multinational corporations and leading national counsel, the Supreme Court finally took an interest.

\section{The Supreme Court Limits ATS Litigation: Sosa and Kiobel}

The Supreme Court's first straight-on encounter with the ATS arose out of a Drug Enforcement Administration (DEA) operation gone awry in Mexico. ${ }^{179}$ Enrique Camarena-Salazar was abducted, tortured, and killed in 1985 while working undercover in Mexico. The DEA subsequently identified a Mexican physician, Humberto

174. HufBauer \& Mitrokostas, supra note 10, at 37-43 (attempting to quantify these impacts).

175. See Childress, supra note 6, at 713 n.25.

176. See, e.g., Reinsch, supra note 173, at 29-30.

177. See Chambers, supra note 154, at 15 (reporting that the Unocal settlement provided both "direct compensation and 'substantial assistance' via funds for programs to improve living conditions, health care, and education").

178. Cf. Childress, supra note 6, at 725 (suggesting that some human-rights plaintiffs may sue under the ATS rather than more legally promising foreign or state law theories because of the political impact of branding the defendant as a violator of international law).

179. Sosa v. Alvarez-Machain, 542 U.S. 692 (2004). The Court did consider an ATS claim in Argentine Republic v. Amerada Hess Shipping Corp., 488 U.S. 428 (1989), which was a suit by two Liberian corporations against Argentina for an attack on their oil tanker during the Falklands War. The Court held that the Foreign Sovereign Immunities Act (FSIA), 28 U.S.C. $\$ 1330$ et seq., provides the exclusive jurisdictional vehicle for suits against foreign nations, preempting jurisdiction under the ATS. Amerada Hess, 488 U.S. at 434-39; see also Koh, Transnational Public Litigation, supra note 1, at 2372 (noting that Amerada Hess "has chilled international tort suits against foreign sovereigns"). 
Alvarez-Machain, as having assisted Camarena's kidnappers by keeping Camarena alive for further torture. When Mexico refused to extradite Dr. Alvarez to the United States, the DEA hired two Mexican nationals, including Jose Francisco Sosa, to kidnap Alvarez and bring him to El Paso. A federal trial court acquitted Alvarez, however, and he then sued both the United States and Sosa. ${ }^{180}$ Alvarez's claims against Sosa rested on the ATS, alleging arbitrary arrest and detention in violation of CIL. ${ }^{181}$

In Sosa v. Alvarez-Machain, ${ }^{182}$ the Court rejected Alvarez's claim. Justice Souter's majority opinion resolved some longstanding ATS debates but left considerable uncertainty in its wake. The Court found "implausible" Alvarez's argument that the ATS itself created a cause of action for violations of international law. "As enacted in 1789," Souter said, "the ATS gave the district courts 'cognizance' of certain causes of action, and the term bespoke a grant of jurisdiction, not power to mold substantive law." ${ }^{184}$ But the Court also rejected Sosa's suggestion "that the ATS was stillborn because any claim for relief required a further statute expressly authorizing adoption of causes of action." "[T] 185 First Congress did not pass the ATS as a jurisdictional convenience to be placed on the shelf for use by a future Congress," the Court said, concluding that the statute was "meant to have a practical effect." ${ }^{186}$ Although the ATS did not create a federal cause of action, it presupposed the existence of such a cause of action. The right to sue in ATS cases is thus best understood as an implied right of action created by federal common law. ${ }^{187}$

180. See Sosa, 542 U.S. at 697-99. Alvarez brought his claim against the United States under the Federal Tort Claims Act (FTCA), 28 U.S.C. $\$ \S 1346(b)(1), 2671-80$, but it foundered under the FTCA's statutory exception barring claims "arising in a foreign country," $\$ 2680(\mathrm{k})$. See Sosa, 542 U.S. at 699.

181. See id. at 734-36.

182. Sosa v. Alvarez-Machain, 542 U.S. 692 (2004).

183. Id. at 713 .

184. Id.

185. Id. at 714 .

186. Id. at 719 .

187. See id. at 724 ("The jurisdictional grant is best read as having been enacted on the understanding that the common law would provide a cause of action for the modest number of international law violations with a potential for personal liability at the time."); see also Khulumani v. Barclay Nat'l Bank Ltd., 504 F.3d 254, 265 (2d Cir. 2007) (Katzmann, J., concurring) ("Sosa makes clear that all ATCA litigation is in fact based on federal common law, rather than a statutory cause of action."); Casto, New Federal Common Law, supra note 23, at 638 ("Sosa squarely holds that ATS litigation is based upon a federal common law cause of action and involves judicial lawmaking."); Carlos M. Vázquez, Things We Do With 
Sosa's recognition of a federal-common-law cause of action obviated one longstanding debate about the ATS's constitutionality. That debate had focused on whether ATS cases "arise under" federal law for purposes of Article III. But as Justice Holmes famously observed, "A suit arises under the law that creates the cause of action." 188 Sosa's conclusion that the ATS presupposes an implied federal right of action under federal common law thus disposes of the Article III objection to Filártiga suits. And because Article III is satisfied so long as there is a "federal element" in the suit, ${ }^{189}$ it no longer matters whether the CIL principles that supply the rule of decision are also federal in nature. It is not uncommon, after all, for a plaintiff's case to rely on one sort of law for the right to sue and another sort of law for the substantive rule of decision. ${ }^{190}$ Sosa thus moots the longstanding debate about whether CIL is "federal" within the meaning of Article III-at least for purposes of the ATS. Whether or not CIL is federal common law, the Sosa cause of action

Presumptions: Reflections on Kiobel v. Royal Dutch Petroleum, 89 Notre Dame L. ReV. 1719, 1725 (2014) [hereinafter Vázquez, Presumptions]; Ernest A. Young, Response, Federal Suits and General Laws: A Comment on Judge Fletcher's Reading of Sosa v. Alvarez-Machain, 93 VA. L. REV. IN BRIEF 33 (2007), available at http://www.virginialawreview.org/sites/virginialawreview .org/files/young.pdf [hereinafter Young, Comment on Fletcher]. The other logical possibility would be to ground the cause of action in international law, but even proponents of ATS litigation have not asserted that international law supports a right to sue in Filártiga cases. See, e.g., BETH STEPHENS \& MiCHAEL RATNER, INTERNATIONAL HUMAN RIGHTS LITIGATION IN U.S. COURTS 112-18 (1996) (urging federal courts to imply a right of action under domestic law); Casto, Protective Jurisdiction, supra note 110, at 475 ("There is serious doubt . . . whether international law, unassisted by domestic law, creates a tort remedy that may be invoked in domestic courts by private individuals."); Ralph G. Steinhardt, Fulfilling the Promise of Filártiga: Litigating Human Rights Claims Against the Estate of Ferdinand Marcos, 20 YALE J. INT'L L. 65, 101 (1995) (acknowledging that "no other nation invites such cases into its courts").

188. See Am. Well Works Co. v. Layne \& Bowler Co., 241 U.S. 257, 260 (1916); see also Young, Comment on Fletcher, supra note 187, at 35-36 (elaborating on this reading of Sosa). American Well Works construed the statutory reach of 28 U.S.C. $§ 1331$, but its conclusion applies a fortiori to Article III itself. A federal right of action is not a necessary condition for arising under jurisdiction, even under $\S 1331$, but it is certainly a sufficient one. See RICHARD H. FAllon, JR., John F. MANNing, Daniel J. Meltzer \& DAVID L. Shapiro, Hart AND WeChSLER's The Federal COURTS AND THE Federal System 864 (6th ed. 2009) [hereinafter HART \& WECHSLER].

189. See Osborn v. Bank of the U.S., 22 U.S. (9 Wheat.) 738, 822-23 (1824).

190. See, e.g., Merrell Dow Pharm., Inc. v. Thompson, 478 U.S. 804 (1986) (involving a state tort claim in which plaintiffs invoked breach of a federal regulatory standard to establish the element of fault); Federal Tort Claims Act, 28 U.S.C. $§ 1346(\mathrm{~b})$ (providing a federal right of action against federal officers, but incorporating state law to provide the standard of liability). See generally Casto, New Federal Common Law, supra note 23, at 639-40 (discussing analogous "hybrid" causes of action in domestic law); Young, Comment on Fletcher, supra note 187, at 3435 (developing this point). 
is, and that is enough for Filártiga suits to arise under federal law for purposes of Article III. ${ }^{191}$

Justice Souter's opinion in Sosa did, however, impose significant limits on the substance of ATS claims. ${ }^{192}$ The historical record indicated that "Congress intended the ATS to furnish jurisdiction for a relatively modest set of actions alleging violations of the law of nations"-primarily involving assaults on ambassadors, violations of safe conducts, and piracy. ${ }^{193}$ Although the majority rejected the notion that federal courts are "categorically precluded ... from recognizing a claim under the law of nations as an element of common law," it insisted that "any claim based on the present-day law of nations [must] rest on a norm of international character accepted by the civilized world and defined with a specificity comparable to the features of the 18th-century paradigms we have recognized." ${ }^{194}$ The

191. For general discussions of Sosa's impact on the debate over CIL, compare Curtis A. Bradley, Jack L. Goldsmith \& David H. Moore, Sosa, Customary International Law, and the Continuing Relevance of Erie, 120 HARV. L. REV. 869 (2007) (reading Sosa to validate the revisionist critique of CIL), with William S. Dodge, Customary International Law and the Question of Legitimacy, 120 HARV. L. REV. F. 19 (2007), available at http://www.harvard lawreview.org/media/pdf/dodge.pdf (accusing Bradley, Goldsmith, and Moore of misreading Sosa). My own view is that Sosa is incompatible with the "modern position" that CIL is federal common law, and that the best reading of Sosa largely supports the revisionist view. See Ernest A. Young, Sosa and the Retail Incorporation of International Law, 120 HARV. L. REV. F. 28 (2007), available at http://www.harvardlawreview.org/forum/issues/120/feb07/young.pdf [hereinafter Young, Retail Incorporation]. Whether or not one agrees with that reading, internationalists like Ralph Steinhardt are simply wrong to assert that, under Sosa, "the courts may do the one thing that the 'revisionists' said was illegitimate, viz., infer a cause of action from customary international law." Ralph G. Steinhardt, The Traffic Light Theory of Sosa v. AlvarezMachain, 101 ProceEdings of THE AM. SoC'Y OF INT'L L. 272, 273 (2007) [hereinafter Steinhardt, Traffic Light]. As Professor Steinhardt has acknowledged elsewhere, there is no customary international practice permitting Filártiga-type suits; the United States stands alone in that regard. See Steinhardt, Marcos, supra note 187, at 101. That is why Sosa said that federal courts may "recognize private claims under federal common law." Sosa, 542 U.S. at 732 (emphasis added); see also supra note 187 (collecting internationalist sources rejecting the idea of resting a cause of action on international law).

192. See, e.g., Steinhardt, Traffic Light, supra note 191, at 273 ("Sosa's 'yellow light' is its rule of evidence that an international norm can be actionable under the ATS only if it is 'specific, universal, and obligatory."').

193. Sosa, 542 U.S. at 720; see also id. ("[T]he common law appears to have understood only those three ... as definite and actionable, or at any rate, to have assumed only a very limited set of claims. As Blackstone had put it, 'offences against this law [of nations] are principally incident to whole states or nations,' and not individuals seeking relief in court." (quoting 4 WILLIAM BLACKSTONE, COMMENTARIES ON THE LAWS OF ENGLAND 68 (1769))).

194. Id. at 725; see id. at 732 ("[F]ederal courts should not recognize private claims under federal common law for violations of any international law norm with less definite content and acceptance among civilized nations than the historical paradigms familiar when $\S 1350$ was enacted."). Importantly, this was a requirement that actionable CIL be as determinate as these 
Court derived this constraint from concerns about both the legitimacy of judicial lawmaking grounded in Erie Railroad Co. v. Tompkins ${ }^{195}$ and the risk of interfering with foreign policy. ${ }^{196}$

These cautions proved "fatal to Alvarez's claim," 197 which relied upon a customary international norm barring arbitrary kidnapping or detention. As the Court construed his complaint, "Alvarez... invoke[d] a general prohibition of 'arbitrary' detention defined as officially sanctioned action exceeding positive authorization to detain under the domestic law of some government." ${ }^{198}$ But the Court found "little authority that a rule so broad has the status of a binding customary norm today," and it noted with evident concern that such a sweeping prohibition would "support a cause of action in federal court for any arrest, anywhere in the world, unauthorized by the law of the jurisdiction in which it took place." "199] "[Athough it is easy to say that some policies of prolonged arbitrary detentions are so bad that those who enforce them become enemies of the human race," Justice Souter wrote, "it may be harder to say which policies cross that line with the certainty afforded by Blackstone's three common law offenses. ${ }^{200}$ Under the circumstances, the Court was simply not prepared to exercise its "residual common law discretion" to vindicate an "aspiration" for stricter limits on arrest and detention. ${ }^{201}$

Both the human-rights community and ATS skeptics claimed Sosa as a victory. EarthRights International called Sosa "a crucial victory for human rights, "202 and Martin Flaherty announced that Sosa's "import is to confirm that international custom was part of

common-law examples-not an effort to freeze the content of actionable CIL at the commonlaw baseline. Compare, e.g., Tel-Oren v. Libyan Arab Republic, 726 F.2d 774, 816 (D.C. Cir. 1984) (Bork, J., concurring) (arguing that ATS claims should be limited to the offenses recognized in the Founding era), with Dodge, Historical Origins, supra note 120, at 241-43 (criticizing this view).

195. Erie R.R. Co. v. Tompkins, 304 U.S. 64 (1938); see also Bradley, Goldsmith \& Moore, supra note 191, at 902-10 (discussing Erie's relevance to Sosa).

196. See Sosa, 542 U.S. at 725-26 (citing Erie as counseling against judicial creation of private rights to sue); $i d$. at 727 (citing foreign-policy concerns as a reason for limiting implied rights of action in the ATS context).

197. Id. at 725 .

198. Id. at 736 .

199. Id.

200. Id. at 737 .

201. Id. at 738 .

202. EarthRights International, In Our Court: ATCA, Sosa, and the Triumph of Human Rights 5 (2004), available at http://www.earthrights.org/sites/default/files/publications/in-ourcourt.pdf. 
judicially enforceable federal law even in the absence of a statute." ${ }^{203}$ Beth Stephens was more circumspect but nonetheless optimistic, claiming that the lower courts had acted "cautiously" under Filártiga, and that " $[t]$ he Supreme Court validated their cautious approach in Sosa, preserving a measured mechanism for human rights accountability that affirms a narrow but very significant role for U.S. domestic courts in providing redress for victims of egregious human rights abuses." ${ }^{204}$ Filártiga's leading academic critics, on the other hand, saw Sosa as a clear rejection of the "modern position" that CIL is supreme federal law, readily enforceable by American courts. ${ }^{205}$ And the business community "welcome[d] the Court's ruling" as "clearly indicat[ing] that the ATS should not be used to institute foreign policy in American courts." 206

The Court revisited the ATS in Kiobel v. Royal Dutch Petroleum Co. ${ }^{207}$ limiting the ATS even more sharply. The plaintiffs were residents of Ogoniland, a region of Nigeria in which the defendant corporations were engaged in oil exploration and production. Plaintiffs alleged that the defendants enlisted Nigerian government forces to suppress environmental protests against the defendants' operations, and that those government agents committed extrajudicial killings, torture, and other human-rights violations. The U.S. Court of Appeals for the Second Circuit dismissed the complaint on the ground that the law of nations does not recognize corporate liability, barring any ATS claim against the defendants. ${ }^{208}$ The Supreme Court granted certiorari to consider that question, but after oral argument the Court ordered supplemental briefing and argument to consider "[w]hether and under what circumstances the [ATS] allows courts to

203. Martin S. Flaherty, The Future and Past of U.S. Foreign Relations Law, 67 LAW \& CONTEMP. PROBS. 169, 173 (2004); see also, e.g., Harold Hongju Koh, The Ninth Annual John Hager Lecture, The 2004 Term: The Supreme Court Meets International Law, 12 TULSA J. COMP. \& INT'L L. 1, 12 (2004) (contending that "all of the . . circuits have [embraced the modern position] (and now the U.S. Supreme Court has as well, in the Alvarez-Machain case)").

204. Beth Stephens, Sosa v. Alvarez-Machain: "The Door Is Still Ajar" For Human Rights Litigation in U.S. Courts, 70 BROOK. L. REV. 533, 567 (2004) [hereinafter Stephens, Sosa].

205. See Bradley, Goldsmith \& Moore, supra note 191, at 902; see also Young, Retail Incorporation, supra note 191 (taking a similar view).

206. Elizabeth Ann Chandler, NFTC and USA*Engage Cite U.S. Supreme Court Decision to More Narrowly Define Alien Tort Provision as Important Step in Curbing Erroneous Lawsuits, NAT'L FOREIGN TRADE COUNCIL (June 30, 2004) (quoting Bill Reinsch), available at http://www.nftc.org/newsflash/newsflash.asp?Mode=View\&articleid=1691.

207. Kiobel v. Royal Dutch Petroleum Co., 133 S. Ct. 1659 (2013).

208. Kiobel v. Royal Dutch Petroleum Co., 621 F.3d 111, 120 (2d Cir. 2010). 
recognize a cause of action for violations of the law of nations occurring within the territory of a sovereign other than the United States." ${ }^{209}$ In June of 2013, the Court held that the ATS generally does not permit extraterritorial suits; hence, the Court unanimously concluded that "petitioners' case seeking relief for violations of the law of nations occurring outside the United States is barred." 110

Chief Justice Roberts, writing for the Court's five conservatives, relied primarily on the presumption against extraterritoriality-a canon of statutory construction holding that "[w]hen a statute gives no clear indication of an extraterritorial application, it has none."211 "This presumption," the Chief Justice wrote, "serves to protect against unintended clashes between our laws and those of other nations which could result in international discord." 212 More generally, it "helps ensure that the Judiciary does not erroneously adopt an interpretation of U.S. law that carries foreign policy consequences not clearly intended by the political branches." ${ }^{213}$ Under this presumption, Kiobel was an easy case because "all the relevant conduct took place outside the United States." ${ }^{214}$ All the parties were foreign as well. Although the Court acknowledged that other cases might present a more difficult question, it insisted that "even where the claims touch and concern the territory of the United States, they must do so with sufficient force to displace the presumption against extraterritorial application." ${ }^{215}$ Kiobel thus seemed to rule out foreign-

\footnotetext{
209. Kiobel v. Royal Dutch Petroleum Co., 132 S. Ct. 1738, 1738 (2012).

210. Kiobel, 133 S. Ct. at 1669.

211. Id. at 1664 (quoting Morrison v. Nat'l Austl. Bank Ltd., 561 U.S. 247, 255 (2010)); see also EEOC v. Arabian Am. Oil Co. (ARAMCO), 499 U.S. 244, 248 (1991) (recognizing a "longstanding principle of American law 'that legislation of Congress, unless a contrary intent appears, is meant to apply only within the territorial jurisdiction of the United States" (quoting Foley Bros., Inc. v. Filardo, 336 U.S. 281, 285 (1949))).

212. Id. (quoting $A R A M C O, 499$ U.S. at 248).

213. Id

214. Id. at 1669 .

215. Id. Justice Alito, with Justice Thomas, joined the majority opinion but wrote separately to suggest a narrower view, under which "a putative ATS cause of action will fall within the scope of the presumption against extraterritoriality - and will therefore be barred—unless the domestic conduct is sufficient to violate an international law norm that satisfies Sosa's requirements of definiteness and acceptance among civilized nations." Id. at 1670 (Alito, J., concurring). Although Alito plainly meant to push the ATS in a narrower direction, he may have encouraged future courts to read the majority opinion more narrowly. After all, Alito opined that the majority's discussion of claims that "touch and concern the territory of the United States" "obviously leaves much unanswered," and he suggested that "perhaps there is wisdom in the Court's preference for this narrower approach." Id. at 1669-70.
} 
cubed cases under the ATS, and it suggested a tough road for other ATS claims as well.

Kiobel was unanimous as to its result, and that is worth pausing over for a moment: Although most observers predicted a closely divided court split along political lines, ${ }^{216}$ it turned out there was no support for entertaining a representative example of second-wave ATS litigation. Eugene Kontorovich has noted that "[w]hen the Second and Ninth Circuit[s] began questioning 'foreign cubed' suits a few years ago, the great majority of scholars dismissed [the courts'] claims as entirely spurious. The conventional wisdom was very much on the side of universal jurisdiction over corporate human rights abuses. ${ }^{217}$ But after Kiobel, foreign-cubed claims are gone-and by a 9-0 vote. Despite ATS advocates' widespread belief that "the foreign cubed issue [was] a conservative invention to roll back human rights litigation, ${ }^{218}$ concerns about overextension of implied rights of action and interference with the political branches' conduct of foreign policy turned out to be widely shared.

Notwithstanding Kiobel's unanimous result, its concurring opinions are likely to extend debate about the ATS's scope. Justice Breyer, writing for the Court's four liberals, concurred only in the result and rejected the presumption against extraterritoriality as an appropriate framework for interpreting the ATS. ${ }^{219}$ Breyer suggested instead that jurisdiction should lie under the ATS whenever "(1) the alleged tort occurs on American soil, (2) the defendant is an American national, or (3) the defendant's conduct substantially and adversely affects an important American national interest." $220 \mathrm{He}$ made clear, however, that the national interest "includes a distinct interest in preventing the United States from becoming a safe harbor (free of civil as well as criminal liability) for a torturer or other

216. See, e.g., Eugene Kontorovich, Kiobel and Academic Fall[i]bility, THE VOLOKH CONSPIRACY (Apr. 17, 2013, 12:54 PM), http://www.volokh.com/2013/04/17/kiobel-andacademic-fallability ("Everyone, including myself, predicted a decision closely divided on ideological lines.").

217. Id.

218. Id. For examples, see Stephens, Checks and Balances, supra note 141, at 7.

219. Kiobel, 133 S. Ct. at 1672 (Breyer, J., concurring in the judgment). Justice Breyer reasoned that although the presumption "rests on the perception that Congress ordinarily legislates with respect to domestic, not foreign matters,", "[t]he ATS was enacted with "foreign matters' in mind." Id. at 1672 (quoting Morrison v. Nat'l Austl. Bank Ltd., 561 U.S. 247, 255 (2010)). Moreover, "at least one of the three kinds of activities that we found [in Sosa] to fall within the statute's scope, namely piracy . . normally takes place abroad.” Id.

220. Id. at 1674 . 
common enemy of mankind."221 By citing Filártiga (as well as the Marcos litigation) with approval, Breyer made clear that he would not read the ATS to exclude all foreign-cubed cases. ${ }^{222}$ But by agreeing with the majority that the Kiobel defendants' minimal presence in the U.S. was insufficient, he suggested a minimum condition that alleged violators of international law be found seeking "safe harbor" within the United States. ${ }^{223}$

The broader view of ATS litigation taken by four Justices itself suggests that the universal-jurisdiction vision of the ATS is hardly dead. Justice Kennedy's one-paragraph concurrence strengthened that impression. He noted that "the Court is careful to leave open a number of significant questions regarding the reach and interpretation" of the ATS, and he agreed that "that is a proper disposition." 224 Kennedy warned, moreover, that "[o]ther cases may arise" involving serious human-rights violations "covered neither by the [Torture Victim Protection Act (TVPA)] nor by the reasoning and holding of today's case; and in those disputes the proper implementation of the presumption against extraterritorial application may require some further elaboration and explanation." Without specifying how he might part company with Kiobel's majority in a future case, Kennedy undermined any sense of certainty that the majority opinion might otherwise have imparted.

At least in the near term, post-Kiobel debate about the ATS is likely to focus on two sets of questions: First, was Kiobel right to reject a universal-jurisdiction reading of the ATS? Second, how much scope for human-rights litigation remains after the Court's ruling?

\section{The TROUbLE WITH PRIVATIZED UNIVERSAL JURISDICTION}

A universal-jurisdiction model of ATS litigation has its attractions. The plaintiffs in Filártiga-style cases generally present compelling injuries, and the perpetrators of the charged abuses

221. Id.

222. Id. at 1675 (citing Filártiga v. Peña-Irala, 630 F.2d 876 (2d Cir. 1980)); Hilao v. Marcos (In re Estate of Marcos), 25 F.3d 1467, 1475 (9th Cir. 1994); In re Estate of Marcos Human Rights Litig., 978 F.2d 493, 495-96, 500 (9th Cir. 1992)). Justice Breyer also cited with approval the practice of those countries that 'find 'universal' criminal 'jurisdiction' to try perpetrators of particularly heinous crimes such as piracy and genocide" and that permit related forms of civil suits. Id. at 1676.

223. Id. at 1678 .

224. Id. at 1669 (Kennedy, J., concurring).

225. Id. 
include some of the most notorious figures of the modern era. In this respect, ATS suits illustrate one of the "clear triumphs of the American legal system": "its remarkable ability to hold the powerful to account while treating the weak with some respect."

To the extent that deep-pocket corporate defendants can convincingly be implicated as aiders and abettors, moreover, the second wave of Filártiga litigation offers victims a hope of meaningful compensation that was generally lacking in the first. By imposing liability on powerful economic actors, courts might encourage those actors in turn to pressure foreign governments to clean up their acts. ${ }^{227}$ And in many instances, the domestic situation in the relevant foreign nation is such that an extraterritorial suit in U.S. courts offers the only realistic hope of subjecting the atrocities involved to the rule of law. ${ }^{228}$ As Judge Leval recently observed, ATS suits "give substance to a body of law that is crucial to a civilized world yet so underenforced that it amounts to little more than a pious sham."229

Universalist ATS litigation also promises to boost American courts' involvement in the development of international law. Dean Koh's vision of "transnational public law litigation" envisioned the U.S. federal courts as vital instruments not only for compensating victims and deterring perpetrators of human-rights violations, but also for "norm-enunciation" as participants in the development of

226. David A. Sklansky \& Stephen C. Yeazell, Comparative Law Without Leaving Home: What Civil Procedure Can Teach Criminal Procedure, and Vice Versa, 94 GEO. L.J. 683, 737 (2006).

227. See, e.g., David Scheffer \& Caroline Kaeb, The Five Levels of CSR Compliance: The Resiliency of Corporate Liability Under the Alien Tort Statute and the Case for a Counterattack Strategy in Compliance Theory, 29 BERKELEY J. INT'L L. 334, 336 (2011) (urging that "[t]he end objective" of ATS litigation against corporations "is that the corporate sector can "right the system,' namely by challenging and attempting to correct the governmental or societal challenges to international law principles, ... thus enhancing the social environment for future business growth").

228. See, e.g., Katie Shay, The Wrong Decision for Human Rights, HuFfingtoN PosT, Apr. 18, 2013, http://www.huffingtonpost.com/katie-shay/kiobel-vs-shell_b_3113133.html (complaining that "[t]oday's decision leaves Esther Kiobel and plaintiffs like her with little recourse against some of the largest corporations in the world" and suggesting that corruption and dependency on multinational corporations would prevent any remedy in the Nigerian courts); Brenda Bowser Soder, Kiobel Ruling Undermines U.S. Leadership on Human Rights, HUMAN RIGHTS FIRST (Apr. 17, 2013), available at http://www.humanrightsfirst.org/ 2013/04/17/kiobel-ruling-undermines-u-s-leadership-on-human-rights ("In many countries, especially those with weak and non-independent justice systems and where the government is either the violator or is complicit in human rights violations committed by corporations, the only remedy and the only deterrent is the risk of being held accountable in another country.").

229. Leval, supra note 122 , at 16. 
international human-rights law. "[O]ur constitutional and historical traditions," he insisted, "not only charge the courts with chief responsibility for preventing abuse of state power against individuals, but also with giving domestic meaning to the shared public values expressed by treaties and customary international law."231 ATS cases thus facilitate the U.S. judiciary's involvement in shaping the content of international human-rights law, ${ }^{232}$ and Kiobel is likely to renew longstanding complaints that American courts are too unwilling to construe and enforce international law. ${ }^{233}$

The deterioration of the federal courts' role obviously worries human-rights advocates, who warn that decisions like Kiobel "will undermine the United States' status as a leader on human rights."234 But it should also concern those who worry that international law threatens American interests. After all, international law is hardly likely to become more congenial to American perspectives and interests if American courts get out of the business of construing it. ${ }^{235}$ I will return to these concerns in Part III.

We must also count the costs of transnational public-law litigation in the Filártiga mold, however. Those costs are considerable. They plainly moved the Court in Kiobel, and they are certain to

230. Koh, Transnational Public Litigation, supra note 1, at 2368.

231. Id. at 2396. This conception of the courts' role is in considerable tension with Dean Koh's assertion that domestic courts "find" CIL rather than make it. See id. at 2385; see also Henkin, supra note 134, at 1561-62 ("In a real sense federal courts find international law rather than make it . . . as is clearly not the case when federal judges make federal common law pursuant to constitutional or legislative delegation."). To my mind, the view that federal courts will help shape CIL to the extent that they consider CIL claims under the ATS is considerably more plausible. See Ernest A. Young, Institutional Settlement in a Globalizing Judicial System, 54 DUKE L.J. 1143, 1122 (2005) [hereinafter Young, Institutional Settlement] (arguing that this is a reason to support involvement by domestic courts in international cases).

232. See, e.g., Wuerth, supra note 4, at 24 ("ATS litigation has the potential to play an important role in the development and enforcement of customary international law" because "[d]ecisions of national courts can constitute state practice and evidence of opinio juris.").

233. See, e.g., Ralph G. Steinhardt, Kiobel and the Weakening of Precedent: A Long Walk for a Short Drink, 107 AM. J. INT'L L. 841, 845 (2013) [hereinafter Steinhardt, Long Walk] ("[W]hat is clear in Kiobel is . . a continuing, seemingly visceral resistance to treating modern international law in both treaty and customary form as law of the United States."); see also Koh, Transnational Public Litigation, supra note 1, at 2377 ("Since Sabbatino, American courts have given undue credence to separation of powers and judicial incompetence in international law cases. That decision has unfortunately contracted American courts' once-vibrant, historically important role in the development of international law."); Lea Brilmayer, International Law in American Courts: A Modest Proposal, 100 YALE L.J. 2277, 2278-79 (1991) (lamenting reluctance of American judges to apply international law).

234. Soder, supra note 228.

235. See Young, Institutional Settlement, supra note 231, at 1122. 
profoundly influence the future course of ATS litigation. This Part addresses those costs from two different perspectives. Section A situates both Kiobel and Sosa as part of the Supreme Court's evolving case law concerning implied private rights of action. Implied rights of action are a familiar feature of domestic securities-fraud and employment-discrimination litigation; they also provide a vehicle for constitutional claims against federal officials. In all these fields, the Court has been increasingly reluctant to recognize private rights to sue under federal statutes or the Constitution in the absence of an express statutory provision. Sosa was a rare instance in which the contemporary Court recognized a new implied private right of action (or, more precisely, endorsed an old one), and Kiobel's limitation of that right's extraterritorial effect reflected the Court's more general discomfort with federal-common-law remedies. Just as the Court's implied-rights jurisprudence has become increasingly restrictive in recent years, those same concerns are likely to generate additional constraints on ATS litigation going forward.

We cannot understand Kiobel simply as a foreign-affairs case apart from this more general background of domestic federal-courts doctrine. ${ }^{236}$ Just as domestic principles governing the relations between the state and federal judiciaries provide valuable guidance concerning the relations of domestic and supranational courts, established domestic principles governing remedies and judicial lawmaking should (and do) govern the implied-rights issues posed by Sosa and Kiobel. Kiobel's analysis is thus best understood not as a simple weighing of functional concerns ${ }^{237}$ or even as an application of the extraterritoriality canon in foreign-relations law. ${ }^{238}$ As I explain in Section B, both Kiobel's application of the presumption against extraterritoriality and its analysis of functional concerns about ATS litigation make most sense within the broader framework of concerns about judicially created rights to sue.

Section $\mathrm{C}$ shifts to the perspective of international law and foreign experience with universal jurisdiction. The debate over the scope of ATS litigation is often portrayed as a clash between domestic and international-law concerns. Here, however, the high bar

236. See id. at 1151-63 (arguing that foreign-relations law should not be treated as a distinct field, isolated from domestic public law).

237. See, e.g., Ku \& Yoo, supra note 127, at 181-99 (comparing the institutional competence of courts and political actors in foreign-relations cases).

238. David L. Sloss, Kiobel and Extraterritoriality: A Rule Without Rationale, 28 MD. J. INT'L L. 241, 245-50 (2013). 
for universal jurisdiction in international law and the general reluctance of foreign nations to exercise the universal jurisdiction they do have cut in the same direction as domestic concerns about judicial lawmaking. Even more significant, the criminal nature of universalist prosecutions abroad highlights the unique and unprecedented quality of Filártiga's vision. Simply put, foreign experience suggests that prosecution of universal-jurisdiction cases should remain primarily in public hands, and that the unique qualities of the American civil-justice system are likely to exacerbate the disruptive impact of universal-jurisdiction suits under the ATS.

These points support the Court's decision in Kiobel, notwithstanding early criticism of that decision by internationalist scholars. They also suggest that the Court is likely to decide questions that remain open under the ATS in a similarly restrictive manner-a matter I take up in Part III.

\section{A. Filártiga Claims as Implied Rights of Action}

Proponents of transnational public-law litigation tend to downplay the domestic-law limits on public-law litigation generally. But those limits are well developed and significant in American law. They include a strong presumption against implying private rights to enforce substantive legal norms when Congress has not expressly authorized such suits. Where implied rights have been recognized, similar presumptions limit their scope. And even where Congress has enacted broad private rights of action in public-law cases, such as in 42 U.S.C. § 1983's general right of action against state and local government officials for violations of federal law, the federal courts have narrowed those remedies. If Filártiga claims are to be justified as analogous to domestic public-law litigation, then the substantial limitations on such litigation must be understood and respected.

\section{The General Decline of Implied Private Rights Under Federal} Statutes and the Constitution. The Court appears to have first recognized an implied right of action in $1916,{ }^{239}$ but it created only one more over the next fifty years. ${ }^{240}$ The Court became considerably

239. Tex. \& Pac. Ry. Co. v. Rigsby, 241 U.S. 33,39 (1916).

240. See Tex. \& N.O.R. Co. v. Bhd. of Ry. \& S.S. Clerks, 281 U.S. 548 (1930) (recognizing an implied right to sue under the Railway Labor Act of 1926); see also Cannon v. Univ. of Chi., 441 U.S. 677, 732-42 (1979) (Powell, J., dissenting) (surveying the development of the implication doctrine). 
more generous in the 1960s. J.I. Case Co. v. Borak ${ }^{241}$ - the "high water mark of judicial implication of remedies" ${ }^{242}$-recognized an implied right of action under $\S 14$ (a) of the Securities Exchange Act of 1934, which prohibits fraud in the solicitation of proxy material, and the Court recognized a similar implied right under the Securities and Exchange Commission's general antifraud rule seven years later. ${ }^{243}$ During the same period, the Court implied additional rights under various civil-rights laws. ${ }^{244}$

Implied rights of action soon ran afoul of longstanding concerns about judicial lawmaking, however. As early as 1963, the Court noted that "we are not in the free-wheeling days ante-dating Erie R.R. Co. v. Tompkins. The instances where we have created federal common law are few and restricted." ${ }^{245}$ The Court began to cut back on implied rights in its 1975 decision in Cort v. Ash ${ }^{246}$ rejecting an implied right of action under a criminal provision of the Federal Election Campaign Act. Although the Court recognized an implied right under the nondiscrimination provisions of Title IX of the Education Amendments of 1972 in Cannon v. University of Chicago, ${ }^{247}$ Justice Powell filed a powerful dissent arguing that "a federal court should not infer a private cause of action" under a federal statute "[a]bsent the most compelling evidence of affirmative congressional intent." ${ }^{248}$ Subsequent cases made clear that "Justice Powell lost the battle in Cannon, but he won the war." ${ }^{249}$

Since Cannon, the Court has generally narrowed its inquiry from a broad purposive analysis to a narrower focus on "proof that Congress intended to create a private right of action." ${ }^{250}$ The leading contemporary case is Alexander v. Sandoval, ${ }^{251}$ a 2001 decision

241. J.I. Case Co. v. Borak, 377 U.S. 426 (1964).

242. HART \& WECHSLER, supra note 188 , at 705.

243. See Superintendent of Ins. v. Bankers Life \& Cas. Co., 404 U.S. 6, 13 n.9 (1971).

244. See Cannon, 441 U.S. at 728 (Powell, J., dissenting).

245. Wheeldin v. Wheeler, 373 U.S. 647, 651 (1963) (citing Erie R.R. Co. v. Tompkins, 304 U.S. 64 (1938)).

246. Cort v. Ash, 422 U.S. 66 (1975).

247. Cannon v. Univ. of Chi., 441 U.S. 677 (1979).

248. Id. at 731 (Powell, J., dissenting).

249. HART \& WeChSLER, supra note 188, at 706; see also Daniel P. Tokaji, Public Rights and Private Rights of Action: The Enforcement of Federal Election Laws, 44 IND. L. REV. 113, 126-33 (2010) (tracing the post-Cannon development of the doctrine).

250. HART \& WECHSLER, supra note 188, at 706; see, e.g., Touche Ross \& Co. v. Redington, 442 U.S. 560, 578 (1979) (rejecting an implied right under § 17(a) of the Securities Act of 1934).

251. Alexander v. Sandoval, 532 U.S. 275 (2001). 
rejecting an implied right of action to enforce disparate-impact regulations issued under Title VI of the Civil Rights Act of 1964. Sandoval made clear that "[1]ike substantive federal law itself, private rights of action to enforce federal law must be created by Congress." 252 Hence, courts must determine whether the relevant statute "displays an intent to create not just a private right but also a private remedy." ${ }^{, 253}$ Without such evidence of Congress's intent, "a cause of action does not exist and courts may not create one, no matter how desirable that might be as a policy matter, or how compatible with the statute." "254 The Court thus endorsed Justice Scalia's earlier statement that "“[r]aising up causes of action where a statute has not created them may be a proper function for commonlaw courts, but not for federal tribunals.'

The Court's decisions on implied rights of action for constitutional violations have taken a similar path. Although federal law provides a statutory cause of action against state and local officials for violation of federal constitutional (and some statutory) rights, ${ }^{256}$ no such statutory remedy exists for similar violations by federal officials. In Bivens v. Six Unknown Named Agents of the Federal Bureau of Narcotics, ${ }^{257}$ the Court recognized an implied private right of action for damages under the Constitution itself for individuals injured by a federal official's violation of their constitutional rights. ${ }^{258}$ Emphasizing that " $[\mathrm{t}]$ he present case involves no special factors counselling hesitation in the absence of affirmative action by Congress," the Court held that an individual has an implied right to sue under the Fourth Amendment for damages arising from an unconstitutional search and seizure..$^{259}$

252. Id. at 286 (citing Touche Ross, 442 U.S. at 578).

253. Id. (citing Transamerica Mortg. Advisors, Inc. v. Lewis, 444 U.S. 11, 15 (1979)).

254. Id. at 286-87.

255. Id. at 287 (quoting Lampf, Pleva, Lipkind, Prupis \& Petigrow v. Gilbertson, 501 U.S. 350, 365 (1991) (Scalia, J., concurring in part and concurring in the judgment)).

256. See 42 U.S.C. § 1983.

257. Bivens v. Six Unknown Named Agents of the Fed. Bureau of Narcotics, 403 U.S. 388 (1971)

258. See generally HART \& WECHSLER, supra note 188, at 726-42 (discussing the Bivens remedy); Carlos Manuel Vázquez, State Law, the Westfall Act, and the Nature of the Bivens Question, 161 U. PENN. L. REV. 509 (2013) (surveying the Court's cases in this area). Before Bivens, plaintiffs seeking damages for a constitutional violation by federal officers had to rely on state common-law tort actions. In this scenario, the alleged unconstitutionality of the officer's action would enter the case as a response to the officer's likely defense of official authority. See Bivens, 403 U.S. at 390-91.

259. Bivens, 403 U.S. at 396. 
The Court initially expanded Bivens to other constitutional claims and other types of federal officials. ${ }^{260}$ But just as with the cases dealing with implied rights under federal statutes, the Court switched course in the 1980s. The first set of cases held that Congress's provision of an alternative remedy forecloses Bivens relief, even if that remedy is not as generous to the plaintiff as a Bivens claim might be. ${ }^{261}$ A second set of cases rejected Bivens claims even absent a statutory alternative remedy, based on the existence of "special factors counselling hesitation" about an implied remedy. ${ }^{262}$ Although these cases arose in the military context, the Bivens Court itself included "question[s] of federal fiscal policy" as another such factor, ${ }^{263}$ and lower courts have recognized other "special factors" in a broad set of national-security cases. ${ }^{264}$ One of the Supreme Court's most recent decisions suggests that the mere prospect of opening the door to "an onslaught of Bivens actions" is itself a reason to restrict the right. ${ }^{265}$ Finally, a third set of cases has refused to expand the class of potential defendants in Bivens actions. ${ }^{266}$

260. See, e.g., Carlson v. Green, 446 U.S. 14, 19-20 (1980) (permitting an Eighth Amendment claim for inadequate medical care by federal prison officials); Davis v. Passman, 442 U.S. 228, 244 (1979) (permitting an administrative assistant to a congressman to sue under the Due Process Clause of the Fifth Amendment for alleged gender discrimination that resulted in her termination).

261. See Schweiker v. Chilicky, 487 U.S. 412, 423 (1988) (rejecting a due-process claim by plaintiffs alleging wrongful denial of Social Security disability benefits, based on availability of a statutory remedy); Bush v. Lucas, 462 U.S. 367, 390 (1983) (denying a Bivens remedy for a federal "whistleblower" employee who claimed to have been fired in retaliation for exercising his First Amendment rights, based on the availability of a civil-service remedy).

262. See United States v. Stanley, 483 U.S. 669, 684 (1987) (denying a Bivens remedy to a former serviceman claiming to have been subjected to LSD experiments by military officers without his consent); Chappell v. Wallace, 462 U.S. 296, 304-05 (1983) (rejecting a Bivens suit by Navy-enlisted men against their superior officers alleging racial discrimination).

263. Bivens, 403 U.S. at 396 (citing United States v. Standard Oil Co., 332 U.S. 301, 311 (1947), in which the Court declined to recognize an implied right of action on behalf of the United States against a tortfeasor who negligently injured a soldier).

264. See, e.g., Klay v. Panetta, 758 F.3d 369, 373 (D.C. Cir. 2014); Doe v. Rumsfeld, 683 F.3d 390, 394-96 (D.C. Cir. 2012); Lebron v. Rumsfeld, 670 F.3d 540, 548-55 (4th Cir. 2012); Arar v. Ashcroft, 585 F.3d 559, 563, 574 (2d Cir. 2009) (en banc); Rasul v. Rumsfeld, 563 F.3d 527, 532 n.5 (D.C. Cir. 2009); see generally Stephen I. Vladeck, National Security and Bivens After Iqbal, 14 LEWIS \& CLARK L. REV. 255 (2010) (surveying the cases).

265. See Wilkie v. Robbins, 551 U.S. 537, 562 (2007).

266. Minneci v. Pollard, 132 S. Ct. 617 (2012) (rejecting a Bivens claim under the Eighth Amendment against individual employees of a privately operated federal prison for providing inadequate medical care); Corr. Servs. Corp. v. Malesko, 534 U.S. 61 (2001) (rejecting a Bivens claim under the Eighth Amendment against a private corporation operating a prison on behalf of the federal government); FDIC v. Meyer, 510 U.S. 471 (1994) (rejecting a due-process claim against a federal agency). 
The upshot is that "three decades after its inception, Bivens appeared intact at least on its own facts, but its successful extension into any new contexts seem[s] decidedly unlikely.. ${ }^{267}$ The Court has been virtually unanimous in refusing to extend the Bivens right of action in every circumstance presented over the last three decades. ${ }^{268}$ This bleak outlook, moreover, is of a piece with the more general decline of implied rights of action in the statutory context. As Justice Scalia has explained, "Bivens is a relic of the heady days in which this Court assumed common-law powers to create causes of action." ${ }^{269}$ Across the board, the Court has been hostile to judicial recognition of private rights to sue for over three decades. ${ }^{270}$

Finally, and somewhat surprisingly, the Court has likewise narrowed the scope of statutory rights to sue under the general federal civil-rights statute, 42 U.S.C. $§ 1983$. That statute provides an express right of action against persons acting "under color of" state law-generally state and local officials-when they violate "the Constitution and laws" of the United States. ${ }^{271}$ Although $\S 1983$ remains a broad and powerful statute, the Court has recognized several important limits over the past several decades. In particular, the Court has said that narrower remedies specific to particular federal statutes may supersede $\S 1983$ 's broad right to sue, ${ }^{272}$ and it has frequently held that particular federal statutes simply do not create

267. Vladeck, supra note 264, at 265.

268. See generally Malesko, 534 U.S. at 68 (noting that since 1980, the Court has "consistently refused to extend Bivens liability to any new context or new category of defendants"); Elliot J. Weingarten, Minneci v. Pollard and the Uphill Climb to Bivens Relief, 7 DUKE J. CONST. L. \& PUB. POL'y SidEBAR 95, 95 (2012) ("Over the past thirty years, the Court has consistently denied Bivens expansion to new categories of plaintiffs."); Laurence H. Tribe, Death by a Thousand Cuts: Constitutional Wrongs Without Remedies After Wilkie v. Robbins, 2007 CATO Sup. CT. REV. 23, 26 (2007) (concluding that Bivens is "on life support with little prospect of recovery").

269. Malesko, 534 U.S. at 75 (Scalia, J., concurring).

270. See, e.g., ERWIN CHEMERINSKY, FEDERAL JURISDICTION $§ 6.3 .3$ (5th ed. 2007) ("In general, the Supreme Court has been reluctant to create new causes of action, even in areas where it has been willing to develop common law rules."); see also Daniel J. Meltzer, The Supreme Court's Judicial Passivity, 2002 SUP. CT. REV. 343, 343, 357-62 (characterizing the Court's implied-right-of-action cases as part of a broader trend in which "the Court sounds the theme that its power (or, more generally, that of the federal courts) is sharply limited and that Congress has primary, if not exclusive, responsibility for fleshing out the operation of schemes of federal regulation").

271. 42 U.S.C. $\$ 1983$.

272. See, e.g., City of Rancho Palos Verdes v. Abrams, 544 U.S. 113 (2005); Middlesex Cty. Sewerage Auth. v. Nat'l Sea Clammers Ass'n, 453 U.S. 1 (1981); HART \& WECHSLER, supra note 188 , at $970-72$. 
individually enforceable rights. ${ }^{273}$ These cases, which cite the Court's implied-right-of-action jurisprudence, are somewhat surprising given $\S 1983$ 's express provision for a private remedy. ${ }^{274}$ In any event, even under $§ 1983$ - where textual and historical support for federal private rights of action is strongest-we see a strong narrowing trend. That trend may indicate a general skepticism of private enforcement; it may also reflect the modern proliferation of express rights to sue under specific statutory schemes. But the direction of doctrinal movement is unmistakable.

This, then, is the doctrinal landscape that any assertion of an implied private right of action must confront. The remainder of this Section fits Sosa's implied right of action for violations of the law of nations into this framework. Justice Scalia noted in Sosa that Bivens "provides perhaps the closest analogy" to ATS claims, ${ }^{275}$ and the Sosa majority cited recent cases rejecting implied rights in both constitutional and statutory cases as reasons for caution about claims like Sosa's under the ATS. ${ }^{276}$ This landscape will seriously constrain the scope of ATS litigation going forward.

2. Sosa's Translation Problem and the Domestic-Law Limits on Private Rights Under the ATS. In Sosa, the Supreme Court recognized that "the ATS is a jurisdictional statute creating no new causes of action," but nonetheless found that "[t]he jurisdictional grant is best read as having been enacted on the understanding that the common law would provide a cause of action for the modest number of international law violations with a potential for personal liability at the time" of its enactment. ${ }^{277}$ This cause of action is best understood as an implied right of action under federal common law. Some of the limits on that cause of action come from international law, in the sense that the Court has understood ATS claims as limited to a subset of rights that international law recognizes with requisite

273. See, e.g., Gonzaga Univ. v. Doe, 536 U.S. 273, 273 (2002) (construing the Family Educational Rights and Privacy Act); HART \& WECHSLER, supra note 188, at 968-70.

274. These decisions may reflect skepticism about the Court's decision in Maine $v$. Thiboutot, 448 U.S. 1 (1980), which extended $\S 1983$ to cover all federal statutory violations despite significant historical evidence indicating a narrower intent. See HART \& WECHSLER, supra note 188 , at $967-68$.

275. Sosa v. Alvarez-Machain, 542 U.S. 692, 743 (Scalia, J., concurring in part and in the judgment).

276. See id. at 727 (majority opinion) (citing Corr. Servs. Corp. v. Malesko, 534 U.S. 61, 68 (2001); Alexander v. Sandoval, 532 U.S. 275, 286-87 (2001)).

277. Id. at 724 . 
clarity. Hence, the Sosa right enforces "norm[s] of international character accepted by the civilized world and defined with a specificity comparable to... the 18th-century paradigms we have recognized." ${ }^{278}$ But the Court also made clear that ATS claims are limited not only by the substantive content of international law, but also by a broader set of concerns about federal judicial lawmaking ${ }^{279}$ and its potential to interfere with the conduct of foreign affairs by the political branches of the U.S. government. ${ }^{280}$ These latter concerns arise from domestic law, resting on the likely purposes of the ATS itself and the demands of the Constitution's separation of powers.

It is thus a necessary, but not sufficient, condition that ATS plaintiffs ground their claims in well-established principles of international law. Domestic law also constrains ATS claims. Sosa emphasized three legal changes since the ATS's drafting that provided "good reasons for a restrained conception of the discretion a federal court should exercise in considering a new cause of action." 281 First, post-Erie principles of separation of powers limit the lawmaking role of courts, especially with respect to recognizing implied private rights of action. ${ }^{282}$ Second, separation-of-powers principles also limit judicial intrusion into the conduct of foreign affairs by the President and Congress. ${ }^{283}$ Third, Congress has taken the lead in defining and enforcing international human-rights law, suggesting that courts should confine any implied rights under the ATS to a very narrow scope. ${ }^{284}$ Each of these "good reasons" is a question of domestic law, and each thus supplements the constraints on ATS suits imposed by the substantive reach of international norms. I discuss the first point-limits on implied rights of action - in this Section, then turn to the second and third points in the next Section.

The Founding generation did not think of "causes of action" in the same way that contemporary lawyers do; plaintiffs' rights to sue in

278. Id. at 725

279. See, e.g., Tex. Indus., Inc. v. Radcliff Materials, Inc., 451 U.S. 630, 640 (1981) (noting that instances of federal common law "are "few and restricted"” (quoting Wheeldin v. Wheeler, 373 U.S. 647, 651 (1963))).

280. See, e.g., Banco Nacional de Cuba v. Sabbatino, 376 U.S. 398, 423 (1964) (recognizing the act-of-state doctrine to avoid judicial actions that undermine the conduct of foreign affairs by the political branches).

281. Sosa, 542 U.S. at 725.

282. Id. at 725-27.

283. Id. at 727-28.

284. Id. at 728 . 
the early Republic derived from the common-law "forms of action." 285 Hence, it was enough for Congress to create jurisdiction in the ATS and then rely on the common law for the plaintiff's right to sue. But as the Sosa Court noted, we do not think of the common law in the same way today, nor do we view federal courts as having broad authority to fashion common-law remedies. ${ }^{286}$ Sosa thus posed a difficult problem of translation, requiring the Court to take into account "the interaction between the ATS at the time of its enactment and the ambient law of the era, ${ }^{, 287}$ as well as the changes in that ambient law since Erie. ${ }^{288}$

Undertaking to transpose the Founders' understanding of a tort in violation of the law of nations into the modern context of implied remedies, Justice Souter noted that "the absence of congressional action addressing private rights of action under an international norm is more equivocal than its failure to provide such a right when it creates a statute." ${ }^{289}$ The First Congress, after all, would have considered such norms presumptively enforceable under the common law without need for a statutory remedy. ${ }^{290}$ Crucially, the Court found that the ATS would have been "stillborn" without such a right. ${ }^{291}$

The Court thus concluded that "[ $\mathrm{t}]$ he jurisdictional grant is best read as having been enacted on the understanding that the common law would provide a cause of action for the modest number of international law violations with a potential for personal liability at the time." ${ }^{292}$ This meant that "the First Congress understood that the

285. See generally Anthony J. Bellia, Article III and the Cause of Action, 89 IOWA L. REV. 777 (2004) (describing the common-law understanding of rights to sue); see also Dodge, Historical Origins, supra note 120, at 239 (arguing that requiring an express cause of action for ATS suits "would have mystified the First Congress").

286. Sosa, 542 U.S. at 725-26. Erie itself has been under siege in recent years, and at least some of the attack seems motivated by dissatisfaction with the limits Erie places on the domestic reception and vindication of CIL. See Craig Green, Repressing Erie's Myth, 96 CALIF. L. REV. 595, 623-24 (2008). For a response, see Young, Erie, supra note 24.

287. Sosa, 542 U.S. at 714.

288. See Sosa, 542 U.S. at 725-27 (discussing the impact of Erie). On translation as a problem of interpretation, see generally Lawrence Lessig, Fidelity in Translation, 71 TEX. L. REV. 1165 (1993).

289. Sosa, 542 U.S. at 714.

290. See id. (concluding that "history and practice give the edge" to the view that "torts in violation of the law of nations would have been recognized within the common law of the time"). The Court noted, however, that only "few . . . torts in violation of the law of nations were understood to be within the common law." Id. at 720.

291. Id. at 714 .

292. Id. at 724 . 
district courts would recognize private causes of action for certain torts in violation of the law of nations.. ${ }^{293}$ The only way to replicate this authority under contemporary jurisprudence-assuming that the ATS is itself purely jurisdictional ${ }^{294}$-would be to recognize an implied right of action as a matter of federal common law. To impose onto the venerable Judiciary Act the current doctrine's insistence on strong evidence of Congress's intent to create a federal remedy would prevent the federal courts from hearing a significant set of cases that the ATS was clearly intended to cover.

My own view is that although Justice Souter's effort at translation made Sosa more complex, it is the only way to be faithful both to contemporary jurisprudential categories and to what the framers of the first Judiciary Act tried to achieve. The difficulty is whether Souter's approach gave adequate effect to legal developments since the Founding. As he acknowledged, "the prevailing conception of the common law has changed since 1789," and along with "that conceptual development in understanding common law has come an equally significant rethinking of the role of the federal courts in making it." ${ }^{295}$ In the "ambient law" of our era, "a decision to create a private right of action is one better left to legislative judgment." ${ }^{296}$ And although the majority opinion emphasized over and over that its implied ATS cause of action should be narrow, its statement that "the door is still ajar ... and thus open to a narrow class of international norms today" left a wide scope for creativity in the lower federal courts. ${ }^{297}$

Justice Scalia's partial concurrence focused on this potential for lower-court adventurism. He noted that the standard the majority intended to constrain lower courts-that the CIL norms in question must be "specific, universal, and obligatory" ${ }^{" 298}$ — was precisely the test

293. Id.

294. See id. at 713 (holding the ATS to be purely jurisdictional, and citing with approval William Casto's declaration that any contrary reading is "simply frivolous") (citing Casto, Protective Jurisdiction, supra note 110, at 480).

295. Id. at 725-26.

296. Id. at 727 (citing Corr. Servs. Corp. v. Malesko, 534 U.S. 61, 68 (2001); Alexander v. Sandoval, 532 U.S. 275, 286-87 (2001)).

297. Id. at 729. Justice Souter said that "the door is still ajar subject to vigilant doorkeeping," $i d$. (emphasis added), and he suggested that some prior lower-court findings of actionable norms "reflect[ed] a more assertive view of federal judicial discretion over claims based on customary international law than the position we take today," id. at 736 n.27.

298. See id. at 732 (majority opinion) (quoting In re Estate of Marcos Human Rights Litig., 25 F.3d 1467, 1475 (9th Cir. 1994)) (explaining that the Court's standard "is generally consistent 
that the lower courts had previously employed in finding a broad range of actionable violations. ${ }^{299}$ Indeed, it was the standard that the Ninth Circuit had applied in upholding the claim for "arbitrary arrest" that the Supreme Court rejected in Sosa itself. ${ }^{300}$ Justice Scalia worried that the lower courts would abuse this discretion, "usurping [Congress's] lawmaking power by converting what they regard as norms of international law into American law." ${ }^{, 301}$ And indeed, Sosa did not seem to put much of a damper on ATS claims. ${ }^{302}$

Justice Scalia's focus on the standard for an actionable CIL violation, however, seems misdirected in hindsight. It is true that, post-Sosa, some lower courts have permitted ATS claims for violations that Justice Souter likely did not intend to reach. ${ }^{303}$ And human-rights advocates have urged plaintiffs to use the ATS for an even broader set of substantive claims. ${ }^{304}$ But most ATS claims advance the same core human-rights concerns of Filártiga, and these claims surely satisfy the "specific, universal, and obligatory standard." ${ }^{305}$ Because Sosa's substantive filter has little bite in this context, transsubstantive limits such as a bar to corporate liability or the presumption against extraterritoriality took on a more prominent role in Kiobel.

with the reasoning of many of the courts and judges who faced the issue before it reached this Court," and citing with approval the "specific, universal, and obligatory" formula from Marcos, 25 F.3d at 1475).

299. See id. at 748 (Scalia, J., concurring in part and in the judgment) (citing Marcos, 25 F.3d at 1475; Kadic v. Karadžić, 70 F.3d 232 (2d Cir. 1995)).

300. See Alvarez-Machain v. United States, 331 F.3d 604, 621 (9th Cir. 2003) (en banc).

301. Sosa, 542 U.S. at 749-50 (Scalia, J., concurring in part and in the judgment).

302. See, e.g., Bellinger, supra note 13, at 5 ("Notwithstanding the [Sosa] Court's directive for restraint, almost four years later, [ATS] litigation has showed no signs of slowing down."); Richard O. Faulk, The Expanding Role of the Alien Torts Act in International Human Rights Enforcement, Class Action Litigation Report, 10 TXLR 294, at 4 (2009) (listing "creative and expansive post-Sosa attempts to invoke the ATS").

303. See, e.g., Sexual Minorities Uganda v. Lively, 960 F. Supp. 2d 304, 315-16 (D. Mass. 2013) (holding that a claim that an anti-gay preacher had aided and abetted the persecution of homosexuals in Uganda passed Sosa's test).

304. See, e.g., Jaclyn Lopez, The New Normal: Climate Change Victims in Post-Kiobel United States Federal Courts, 8 CHARLESTON L. REV. 113, 115 (2013) (arguing "that there is an emerging international norm of limiting contributions to climate change, and that a plaintiff bringing an ATS claim regarding climate change may succeed on the merits of the case").

305. See, e.g., Scarborough, supra note 139, at 459 (observing that "[p]ost-Sosa, no one would doubt that claims of extrajudicial killing, state-sponsored rape, and forced labor would qualify under Sosa's analysis to create ATS liability"). But see Enahoro v. Abubakar, 408 F.3d 877, 883-86 (7th Cir. 2005) (holding that torture and extrajudicial killing are not actionable under the ATS). 


\section{B. Extraterritoriality as a Constraint on Sosa's Right of Action}

Chief Justice Roberts's majority opinion in Kiobel rested entirely on the canon of statutory construction "provid[ing] that '[w]hen a statute gives no clear indication of an extraterritorial application, it has none." ${ }^{306}$ The canon is a venerable one, traceable at least as far back as the Court's refusal in 1818 to construe a federal piracy statute to cover a robbery on the high seas by foreign citizens on board a foreign ship. ${ }^{307}$ Like many canons of construction, the presumption against extraterritoriality has both descriptive and normative dimensions. ${ }^{308}$ Descriptively, it "rests on the perception that Congress ordinarily legislates with respect to domestic, not foreign matters." The canon also serves normative values (which Congress may or may not share): It promotes compliance with international law; ${ }^{310}$ it protects the foreign-policy primacy of the political branches; ${ }^{311}$ it avoids clashes between American law and the laws of other jurisdictions; and it limits foreigners' exposure to the wild and woolly ways of the American civil-justice system. ${ }^{312}$

306. Kiobel v. Royal Dutch Petroleum Co., 133 S. Ct. 1659, 1664 (2013) (quoting Morrison v. Nat'l Austl. Bank Ltd., 561 U.S. 247, 255 (2010)).

307. United States v. Palmer, 16 U.S. (3 Wheat.) 610, 643 (1818); see also William S. Dodge, Understanding the Presumption Against Extraterritoriality, 16 BERKELEY J. INT'L L. 85, 85 n.2 (1998) (collecting other early instances).

308. See id. at 112-23 (surveying reasons for the canon). On the distinction between descriptive and normative canons, see generally Daniel B. Rodriguez, The Presumption of Reviewability: A Study in Canonical Construction and Its Consequences, 45 VAND. L. REV. 743 , 749 (1992) (distinguishing between "descriptive" canons, which "implement what Congress really wanted, but expressed inartfully or incompletely," and "normative" canons, which "implement an important 'public value' through the mechanism of statutory interpretation"); Stephen F. Ross, Where Have You Gone, Karl Llewellyn? Should Congress Turn Its Lonely Eyes to You?, 45 VAND. L. REV. 561, 563 (1992) (same); see also Ernest A. Young, Constitutional Avoidance, Resistance Norms, and the Preservation of Judicial Review, 78 TEX. L. REV. 1549, 1586-87 (2000) [hereinafter Young, Constitutional Avoidance].

309. Morrison, 561 U.S. at 255; see also Smith v. United States, 507 U.S. 197, 204 n.5 (1993) ("[T]he presumption is rooted in a number of considerations, not the least of which is the commonsense notion that Congress generally legislates with domestic concerns in mind.").

310. See, e.g., William S. Dodge, Morrison's Effects Test, 40 Sw. L. REV. 687, 687 (2011) ("The presumption against extraterritoriality was born from the marriage of the Charming Betsy canon ... and an international law rule that jurisdiction was generally territorial."); Sloss, supra note 238 , at $241-42$.

311. See, e.g., Kiobel, 133 S. Ct. at 1669 ("The presumption against extraterritoriality guards against our courts triggering . . . serious foreign policy consequences, and instead defers such decisions ... to the political branches."); Sloss, supra note 238, at 245-46 (calling this the "international relations" rationale).

312. See, e.g., Morrison, 561 U.S. at 270 (worrying that the United States "has become the Shangri-La of class-action litigation for lawyers representing those allegedly cheated in foreign 
Although early commentary has argued that Kiobel is out of step with these justifications ${ }^{313}$ I reach the opposite conclusion. Kiobel was a particularly appropriate case for judicial caution about the extraterritorial reach of American law. I begin, however, with objections that the canon simply does not apply either to the ATS or to Sosa's right of action.

1. Extraterritoriality, Jurisdiction, and Implied Rights of Action. The first difficulty with applying the extraterritoriality canon in Kiobel was that, as Chief Justice Roberts acknowledged, "[w]e typically apply the presumption to discern whether an Act of Congress regulating conduct applies abroad." ${ }^{314}$ The ATS, however, "does not directly regulate conduct or afford relief"; it is, as the Court held in Sosa, "'strictly jurisdictional.", ${ }^{15}$ For many of Kiobel's critics, this renders the presumption irrelevant. Carlos Vázquez, for example, has argued that the extraterritoriality canon is categorically inapplicable to jurisdictional statutes. ${ }^{316} \mathrm{He}$ suggests that the presumption applies only to statutes that regulate conduct. ${ }^{317}$ This objection, however, gives the canon far too narrow a scope.

The problem is that the substantive-jurisdictional distinction is insufficiently clear-cut to bear the weight that critics would place on it. International law has long regulated jurisdiction to prescribe (to regulate conduct) and jurisdiction to adjudicate, suggesting that each raises significant extraterritoriality concerns. ${ }^{318}$ Jurisdiction to decide is, in any event, always to some extent jurisdiction to prescribe a rule for that case. One need not be a hard-core Legal Realist to acknowledge that adjudication frequently involves some degree of lawmaking; applying a preexisting legal standard in a new factual

securities markets"); Paul B. Stephan, Response Essay_Empagran: Empire Building or Judicial Modesty?, in INTERNATIONAL LAW IN THE U.S. SUPREME COURT: CONTINUITY AND CHANGE 553, 554 (David L. Sloss, Michael D. Ramsey \& William S. Dodge eds., 2011); Sloss, supra note 238, at 251-54 (calling this the "domestic judicial policy" rationale).

313. See, e.g., Sloss, supra note 238 , at 243, 246-47, 253-54.

314. Kiobel, 133 S. Ct. at 1664.

315. Id. (quoting Sosa v. Alvarez-Machain, 542 U.S. 692, 713 (2004)).

316. See Vázquez, Presumptions, supra note 187, at 1723; see also Steinhardt, Long Walk, supra note 233, at 841 (charging that "Kiobel is the first time that the presumption against extraterritoriality has been applied to a purely jurisdictional statute").

317. Vázquez, Presumptions, supra note 187, at 1723.

318. Notably, Justice Breyer's concurrence rejecting application of the extraterritoriality canon argued that ATS jurisdiction was consistent with international norms-not that jurisdictional statutes raise no extraterritoriality concerns. See Kiobel, 133 S. Ct. at 1673-77 (Breyer, J., concurring in the judgment). 
context, for example, inevitably shapes the meaning of that standard. And extension of federal jurisdiction to adjudicate claims under international law increases the likelihood that American judges will come into conflict with foreign jurists over the meaning of international legal principles. ${ }^{319}$ The potential for judicial lawmaking and transnational disagreement, in turn, creates incentives that influence litigant conduct. The history of federal-courts doctrine is replete with examples of litigants altering their conduct in order to fall within one or another court's jurisdiction to adjudicate. ${ }^{320}$

The extraterritoriality canon's underlying concerns, then, do not fall neatly on one side of a bright line between prescriptive and adjudicative jurisdiction. They suggest that Kiobel's reasoning might apply to other "strictly jurisdictional" statutes, such as the general federal-question statute or the alien-citizen diversity provision, in a future case in which the ATS is not in play. But Kiobel itself is best read as applying the presumption not to the ATS itself, but rather to the implied right of action that Sosa recognized. As Chief Justice Roberts wrote, "the principles underlying the [extraterritoriality] canon of interpretation similarly constrain courts considering causes of action that may be brought under the ATS." ${ }^{321}$ This application gives rise to two further objections: that Sosa does not involve the extraterritorial application of U.S. law, and that the canon in any event does not apply to federal-common-law causes of action.

The first objection notes that "it is debatable whether the Kiobel plaintiffs were even asking U.S. courts to apply U.S. law extraterritorially. Arguably, it would be more accurate to say that the Kiobel plaintiffs were asking U.S. courts to apply international law extraterritorially.",322 The canon should not apply, in other words, because the substantive rules of conduct enforced by Sosa claims

319. See, e.g., Eyal Benvenisti \& George W. Downs, National Courts, Domestic Democracy, and the Evolution of International Law, 20 EUR. J. INT'L L. 59, 71-72 (2009) (acknowledging the risk that greater national-court involvement in deciding international-law questions may lead to more conflict among courts of different nations).

320. See, e.g., Sheldon v. Sill, 49 U.S. (8 How.) 441 (1850) (bank assigned a mortgage to an out-of-state party in order to facilitate access to federal court in a foreclosure suit). Much of the point of federal diversity jurisdiction was to encourage the development of interstate commerce by assuring out-of-state businesses that they would have access to a federal forum in the event of a dispute. See RANDAll BRIDWEll \& RAlph U. WhitTen, The Constitution AND THE COMMON LAW: THE DECline OF THE DOCTRINES OF SEPARATION OF POWERS AND FEDERALISM 67-68 (1977).

321. Kiobel, 133 S. Ct. at 1664.

322. Sloss, supra note 238, at 243. 
derive from international law. ${ }^{323}$ But the Court's implied-right-ofaction jurisprudence has always understood creating a right to sue as itself an important exercise of power. ${ }^{324}$ And that right is a creature of federal-not international-law. ${ }^{325}$ As both supporters and critics have noted, ${ }^{326}$ America's recognition of a private civil remedy for human-rights violations is unique-neither foreign nor international law offers any ready analogues. It ignores reality to characterize Sosa claims as a passive procedural mechanism rather than as an important assertion of American sovereignty with far-reaching consequences. ${ }^{327}$ As such, those claims should be governed by the same general rules of extraterritoriality as other assertions of national legal authority.

The latter objection is that the presumption against extraterritoriality should not apply to determine the scope of federalcommon-law rules (like Sosa's implied right of action), because there is no congressional intent to construe in such cases. ${ }^{328}$ This is an odd argument, because it suggests that courts may impose extraterritorial obligations less easily when there is legislative support for those obligations-that is, an enacted statute-than when the courts themselves have created the right to sue. Canons guide statutory construction by identifying either things Congress is unlikely to want to do (e.g., legislate extraterritorially) or values that are important enough to push back against Congress's likely intent (e.g., avoiding conflict with other nations). It is hard to imagine why either sort of principle should not also constrain courts when they make law on their own. Federal common law is, after all, always subordinate to federal statutes. ${ }^{329}$ Moreover, as Chief Justice Roberts noted, "the danger of unwarranted judicial interference in the conduct of foreign

323. Id.; see also Leval, supra note 122, at 21 (making a similar argument).

324. See, e.g., Cannon v. Univ. of Chicago, 441 U.S. 677, 743 (1979) (Powell, J., dissenting) (stating that implying private rights of action "allows the Judicial Branch to assume policymaking authority vested by the Constitution in the Legislative Branch"); accord Carlos M. Vázquez, Customary International Law as U.S. Law: A Critique of the Revisionist and Intermediate Positions and a Defense of the Modern Position, 86 NOTRE DAME L. REV. 1495, 1504, 1547 (2011) (agreeing that Sosa claims involve an exercise of jurisdiction to prescribe, not just to adjudicate).

325. See supra note 187 and accompanying text.

326. See, e.g., Anderson, supra note 104, at 182; Leval, supra note 122, at 18.

327. See, e.g., KAREN J. Alter, The New Terrain of International Law: Courts, POLITICS, RIGHTS 156 (2014) (characterizing the rise of ATS claims after Filártiga as a critical development shaping the international legal landscape).

328. See Vázquez, Presumptions, supra note 187, at 1731.

329. See, e.g., Am. Elec. Power Co. v. Connecticut, 131 S. Ct. 2527, 2537 (2011); Illinois v. Milwaukee, 451 U.S. 304, 314 (1981). 
policy"-a principal concern underlying the extraterritoriality canon-"is magnified in the context of the ATS, because the question is not what Congress has done but instead what courts may do."

2. Did Congress Intend to Reach Foreign-Cubed Cases? Justice Breyer's primary argument in his Kiobel concurrence did not reject any of this reasoning. He instead suggested that the presumption against extraterritoriality should not apply because "[t]he ATS... was enacted with 'foreign matters' in mind." ${ }^{331}$ David Sloss rightly notes that "[n]o one seriously disputes the proposition that Congress enacted the ATS to influence foreign affairs. Congress's primary goal when it enacted the ATS was to reduce a source of friction with important U.S. allies. ${ }^{, 32}$ In his view-and Breyer's—-that should be sufficient to overcome any presumption that Congress was "primarily concerned with domestic conditions. ${ }^{\$ 333}$

It does not follow, however, that Congress meant federal law to apply extraterritorially simply because it was concerned about "foreign matters." Imagine that in the wake of the Supreme Court's permissive construction of the Takings Clause in Kelo, ${ }^{334}$ Congress worries that local takings of foreign-owned property would offend other nations. It enacts a statute prohibiting (and providing a compensatory remedy to aliens for) "any expropriation in violation of customary international law." This hypothetical statute would have been plainly "enacted with foreign matters in mind," but does that make it more likely that Congress also intended the statute to allow foreign property owners to sue foreign governments for

330. Kiobel v. Royal Dutch Petroleum Co., 133 S. Ct. 1659, 1664 (2013). Cf. David H. Moore, An Emerging Uniformity for International Law, 75 GEO. WASH. L. REV. 1, 37-38 (2006) ("[A]s a rule, congressional intent is the threshold for federal judicial authority to apply [customary international law] as federal law ....").

331. Kiobel, 133 S. Ct. at 1672 (Breyer, J., concurring in the judgment). This point makes more sense as a way of rebutting the presumption-we know that Congress meant to legislate extraterritorially because it was dealing explicitly with international matters- than of rendering the presumption inapplicable. For example, in Morrison the Court evaluated textual evidence that the federal securities laws touch on foreign activities and transactions as evidence to rebut the presumption of extraterritoriality. See Morrison v. Nat'l Austl. Bank Ltd., 561 U.S. 247, 263 (2010). It is not clear whether this distinction makes any practical difference, however.

332. Sloss, supra note 238, at 4 .

333. Id. at 4 (quoting Foley Bros., Inc. v. Filardo, 336 U.S. 281, 285 (1949) (stating the usual presumption)); accord Kiobel, $133 \mathrm{~S}$. Ct. at 1672 (Breyer, J., concurring in the judgment).

334. Kelo v. City of New London, 545 U.S. 469 (2005) (upholding a local government's use of eminent domain to take private residential property and give it to a private corporation in order to promote economic development). 
expropriations taking place in foreign countries? That conclusion would transform a statute meant to avoid international controversy into one guaranteed to engender it.

Parallels to the actual history of the ATS should be obvious. As Chief Justice Roberts pointed out, Congress legislated in response to worries about the capacity of the state courts to provide reliable remedies for law-of-nations violations occurring within American territory, and the federal courts' early applications of the statute likewise involved domestic occurrences. ${ }^{335}$ In this vein, my colleague Curtis Bradley has argued that the "the text and structure of the First Judiciary Act, and the correspondence surrounding it, suggest that Congress viewed at least the law of nations portion of the Alien Tort Statute as an implementation of Article III alienage jurisdiction"that is, as restricted "to suits involving a U.S. citizen defendant." "336 Whether or not one finds Professor Bradley's reading persuasive, its availability (and considerable textual and historical support) demonstrates that a statute may well be concerned with "foreign matters" and yet not meant to apply extraterritorially (especially in the foreign-cubed sense). No one, after all, argues that Congress had anything like contemporary Filártiga-style litigation in mind in $1789 .{ }^{337}$

Nor does Sosa's widely accepted assumption that the ATS was meant to cover piracy demonstrate that Congress intended to permit extraterritorial suits. First, the assumption itself may not be correct. After all, the early Congress passed a specific statute dealing with pirates, and the Marshall Court's piracy cases all involved American parties. ${ }^{338}$ Second, the extraterritoriality presumption aims to prevent clashes with foreign governments and, in particular, foreign law that would potentially apply to conduct regulated by the relevant federal

335. Kiobel, 133 S. Ct. at 1666-67; see Bolchos v. Darrel, 3 F. Cas. 810 (D.S.C. 1795) (No. 1607); Moxon v. The Fanny, 17 F. Cas. 942, 948 (D. Pa. 1793) (No. 9895).

336. Bradley, ATS, supra note 108, at 636-37; see also M. Anderson Berry, Whether Foreigner or Alien: A New Look at the Original Language of the Alien Tort Statute, 27 BERKELEY J. INT'L L. 316, 320-21 (2009) (arguing that the drafting history of the ATSparticularly, the change from "foreigner" to "alien"-indicates Congress's desire to restrict the statute to suits involving foreigners resident in the United States).

337. The Court seemed to have something like Dean Slaughter's broader view in its sights when it denied that "the ATS was passed to make the United States a uniquely hospitable forum for the enforcement of international norms." Kiobel, 133 S. Ct. at 1668.

338. See supra note 70. Indeed, the Court's earliest extraterritoriality case refused to apply the piracy statute extraterritorially. See supra note 307 and accompanying text. 
statute. ${ }^{339}$ Those concerns are particularly attenuated when laws deal with generally stateless entities like pirates. ${ }^{340}$ When Justice Breyer asserted that human-rights violators are "today's pirates," papered over a number of important distinctions, including the frequently close relationship between defendants and foreign governments in contemporary ATS suits, the possibility of interference with legal processes ongoing in the state where the events occurred, and the likelihood that the foreign state may have considerable economic interests at stake. The Chief Justice was right to suggest that "pirates may well be a category unto themselves." ${ }^{342}$

Finally, Professor Vázquez suggests that the Sosa cause of action should overcome the presumption against extraterritoriality because it is based on the Founders' notion of "general" law, and in the eighteenth century such general law would have been understood to apply universally. ${ }^{343}$ This argument misunderstands the relationship between the "general" principles of CIL that provide the rule of decision in ATS suits and the source of the plaintiff's right to sue. As A.J. Bellia has shown, eighteenth-century American plaintiffs derived their right to sue from the English common-law forms of action, not general principles of CIL. ${ }^{344}$ Vázquez acknowledges that international law generally does not confer rights to sue on civil plaintiffs $\mathrm{s}^{345}$ - and I do not understand him to argue that it did in the Founding era, either. The English common law, of course, did not apply universally and

339. See Kiobel, 133 S. Ct. at 1667 ("Applying U.S. law to pirates . . . does not typically impose the sovereign will of the United States onto conduct occurring within the territorial jurisdiction of another sovereign, and therefore carries less direct foreign policy consequences.").

340. Justice Breyer correctly noted that "the robbery and murder that make up piracy do not normally take place in the water; they take place on a ship. And a ship is like land, in that it falls within the jurisdiction of the nation whose flag it flies." Id. at 1672 (Breyer, J., concurring in the judgment). But it is not as if applying American remedies in piracy cases is likely to offend those countries that consider piracy legal and object to their punishment. There aren't any, at least as a general matter. And in any event, we generally punish pirates under the federal piracy statute - not the ATS — through a criminal process that can more readily take into account any such foreign-relations objections that do materialize.

341. Id. at 1672; see also id. at 1672-73.

342. Id. at 1667 (majority opinion); see also Doe v. Exxon Mobil Corp., 654 F.3d 11, 78 (D.C. Cir. 2011) (Kavanaugh, J., dissenting in part) ("Applying the ATS to conduct on the high seas does not pose the risk of conflicts with foreign nations that the presumption against extraterritoriality and the ATS itself were primarily designed to avoid. The high seas are jurisdictionally unique.").

343. See Vázquez, Presumptions, supra note 187, at 1739.

344. See Bellia, supra note 285 , at 785.

345. See Vázquez, Presumptions, supra note 187, at 1725. 
had to be received by positive act in each of the American states. ${ }^{346}$ The common-law provenance of Sosa's right of action thus cannot power an argument that the right applies universally without regard to geography. To the extent that history frames the appropriate bounds of Sosa's right of action, that history indicates that Congress was concerned with a far narrower set of cases in which international law required the United States to provide a remedy_primarily in cases arising in U.S. territory or involving U.S. nationals. ${ }^{347}$

3. Extraterritoriality as a "Special Factor Counselling Hesitation." Alongside arguments about Congress's intent, Chief Justice Roberts invoked concerns about ATS claims causing "unintended clashes between our laws and those of other nations" and "impinging on the discretion of the Legislative and Executive Branches in managing foreign affairs." ${ }^{348}$ These concerns echoed the Court's domestic implied-rights cases. Speaking of implied rights of action to vindicate constitutional principles, for example, the Court has frequently recognized that "the federal courts must make the kind of remedial determination that is appropriate for a common-law tribunal, paying particular heed, however, to any special factors counselling hesitation before authorizing a new kind of federal litigation." ${ }^{349}$ The same reasons supporting a presumption against extraterritoriality in statutory construction thus figured in Kiobel as "special factors counselling hesitation" in extending an implied right of action under federal common law.

Circuit Judge Antonin Scalia made this connection explicit a year before his elevation to the Supreme Court, invoking the specialfactors analysis from the Bivens cases to reject an ATS claim against former Nicaraguan Contras:

Just as the special needs of the armed forces require the courts to leave to Congress the creation of damage remedies against military

346. See, e.g., Ford W. Hall, The Common Law: An Account of Its Reception in the United States, 4 VAND. L. REV. 791 (1951). States incorporated the common law, moreover, only to the extent that each jurisdiction did not decide to modify it by legislative act or later judicial decision. See id. at 798-99.

347. See, e.g., Bellia \& Clark, Law of Nations, supra note 115; Lee, Safe Conduct, supra note 117 , at 902 .

348. Kiobel v. Royal Dutch Petroleum Co., 133 S. Ct. 1659, 1664 (2013) (quoting Sosa, 542 U.S. at 727; EEOC v. Arabian Am. Oil Co. (ARAMCO), 499 U.S. 244, 248 (1991)) (quotation marks omitted).

349. Minneci v. Pollard, 132 S. Ct. 617, 621 (2012) (quoting Wilkie v. Robbins, 551 U.S. 537, 550 (2007) (quoting Bush v. Lucas, 462 U.S. 367, 378 (1983))). 
officers for allegedly unconstitutional treatment of soldiers, ... so also the special needs of foreign affairs must stay our hand in the creation of damage remedies against military and foreign policy officials for allegedly unconstitutional treatment of foreign subjects causing injury abroad. The foreign affairs implications of suits such as this cannot be ignored.... [A]s a general matter the danger of foreign citizens' using the courts in situations such as this to obstruct the foreign policy of our government is sufficiently acute that we must leave to Congress the judgment whether a damage remedy should exist. ${ }^{350}$

The Supreme Court has likewise invoked foreign-affairs and security concerns as reasons to cabin implied federal rights of action. ${ }^{351}$

Those concerns have particular resonance in cases invoking universal jurisdiction. International legal principles governing universal jurisdiction and foreign experience with its exercise tend to underscore the Chief Justice's concerns in Kiobel. Likewise, comparative analysis of foreign and American approaches to civil litigation bears out Kiobel's worry about conflict with foreign legal regimes. The next Section thus fleshes out Kiobel's "special factors" from the perspective of international law and experience.

\section{Universal Jurisdiction in International Perspective}

In international law, universal jurisdiction remains controversial in principle and extremely rare in practice. There are good reasons for that. Even advocates of universal jurisdiction acknowledge that it is "a potentially dramatic extension of judicial power and a corresponding threat to judicial legitimacy., ${ }^{, 352}$ To the extent that consistency with international law is a goal of the extraterritoriality canon, Kiobel's limits on ATS litigation further that goal. It is equally important to recognize, moreover, that the form of universal jurisdiction exercised in Filártiga suits is profoundly different from the universal jurisdiction exercised in human-rights cases by other countries around the world. Universal jurisdiction in foreign practice is a criminal phenomenon.

350. Sanchez-Espinoza v. Reagan, 770 F.2d 202, 208-09 (D.C. Cir. 1985); see also Casto, New Federal Common Law, supra note 23, at 645 ("Because ATS litigation in Sosa's wake is so obviously analogous to Bivens litigation, the same caution is pertinent to crafting tort remedies for violations of international law.").

351. See Vladeck, supra note 264, at 268-75.

352. Slaughter, Universal Jurisdiction, supra note 27, at 168. 
Reading Sosa to recognize a civil form of universal jurisdiction departs from foreign practice in two crucial respects: It wrests control over the initiation and conduct of litigation from public hands, and in particular, away from the Executive branch, which is responsible for conducting foreign policy. And moving human-rights litigation onto the civil side tends to emphasize exceptional aspects of American procedure and remedies that may intensify conflict with foreign legal systems. Foreign experience with universal jurisdiction should make American courts hesitate to expand ATS litigation.

1. Extraterritoriality, Universality, and International Law. Justice Breyer's Kiobel concurrence emphasized that "just as we have looked to established international substantive norms to help determine the [ATS's] substantive reach, so we should look to international jurisdictional norms to help determine the statute's jurisdictional scope. ${ }^{\prime 33}$ Three distinct questions are worth asking: Does international law require the exercise of universal jurisdiction? Does it permit the exercise of such jurisdiction? And even if universal jurisdiction is permitted, is it nonetheless disfavored?

Justice Breyer suggested that universal jurisdiction is not only permitted but required by international law. ${ }^{354}$ Significantly, he did not assert that international custom established this obligation, but rather noted that "the Senate has consented to treaties obliging the United States to find and punish foreign perpetrators of serious crimes committed against foreign persons abroad." ${ }^{355}$ But even the Restatement (Third) acknowledges that each of the treaties that Breyer cited "include[s] an obligation on the parties to punish or extradite offenders." ${ }^{356}$ That is rather different from a requirement to

353. Kiobel, 133 S. Ct. at 1673 (Breyer, J., concurring in the judgment). It is not clear that this analogy works. After all, the very term "universal" jurisdiction fits uncomfortably with the traditional mission of the American federal courts as courts of limited jurisdiction. See, e.g., Kokkonen v. Guardian Life Ins. Co. of Am., 511 U.S. 375, 377 (1994) ("Federal courts are courts of limited jurisdiction. They possess only that power authorized by Constitution and statute, which is not to be expanded by judicial decree. It is to be presumed that a cause lies outside this limited jurisdiction ...." (citations omitted)).

354. Kiobel, 133 S. Ct. at 1676 (Breyer, J., concurring in the judgment).

355. $I d$.

356. RESTATEMENT (THIRD), supra note 22, § 404 Reporters' Note 1, at 257 (emphasis added) (discussing the Convention on the Prevention and Punishment of Crimes Against Internationally Protected Persons, Including Diplomatic Agents, Dec. 28, 1973, 28 U.S.T. 1975, T.I.A.S. No. 8532; Convention for the Suppression of Unlawful Acts Against the Safety of Civil Aviation, Sept. 23, 1971, 24 U.S.T. 565, T.I.A.S. No. 7570; and the Convention for the Suppression of Unlawful Seizure of Aircraft, Dec. 16, 1970, 22 U.S.T. 1641, T.I.A.S. No. 7192). 
"find and punish"; a state party to these treaties may satisfy its obligations without exercising any sort of universal jurisdiction, so long as it hands over perpetrators to other nations willing to prosecute. ${ }^{357}$ These treaties have each been ratified by many, many countries, and yet few of those countries provide for, much less exercise, universal jurisdiction.

It is nonetheless impossible to say that international law prohibits universal jurisdiction. As discussed in Part I, international law has recognized universal jurisdiction in principle for some time. Some of Kiobel's critics, however, suggest that extraterritorial jurisdiction has become so well accepted that the presumption against extraterritoriality is no longer warranted. David Sloss, for example, claims that "the international law rationale for the presumption against extraterritoriality became untenable because international law changed." 358 Professor Sloss relies on a 1927 decision by the Permanent Court of International Justice (a forerunner to today's ICJ) in the Lotus case, ${ }^{359}$ which rejected any "general prohibition to the effect that States may not extend the application of their laws and the jurisdiction of their courts to persons, property and acts outside their territory. ${ }^{\$ 60}$ Instead, the Court said that international law

Each of the post-Restatement treaties that Justice Breyer cited offers signatories a similar choice. See International Convention for the Protection of All Persons from Enforced Disappearance, Art. 9(2) (2006) (requiring that each state party take measures to establish jurisdiction "when the alleged offender is present in any territory under its jurisdiction, unless it extradites or surrenders him or her"), available at http://www.ohchr.org/Documents/Professional Interest/disappearance-convention.pdf (last visited Feb. 4, 2015); Convention Against Torture and Other Cruel, Inhuman or Degrading Treatment or Punishment, Dec. 10, 1984, 1465 U.N.T.S. 85, Arts. 5(2), 7(1) (similar); Geneva Convention (III) Relative to the Treatment of Prisoners of War, Art. 129, Aug. 12, 1949, [1955] 6 U.S.T. 3316, T.I.A.S. No. 3364 (requiring each signatory to "search for persons alleged to have committed ... such grave breaches" and to "bring such persons, regardless of their nationality, before its own courts" or "hand such persons over for trial"). Justice Breyer acknowledged this qualification in his string citation, but he should have qualified his initial statement that these treaties "oblig[e] the United States to find and punish foreign perpetrators of serious crimes committed against foreign persons abroad." Kiobel, 133 S. Ct. at 1676.

357. See, e.g., International Bar Ass'n, Report of the Task Force on Extraterritorial Jurisdiction 154 (2008), available at http://tinyurl.com/taskforce-etj-pdf (last visited Feb. 4, 2015) [hereinafter IBA Task Force] (emphasizing the importance of this distinction).

358. Sloss, supra note 238, at 2.

359. S.S. Lotus (Fr. v. Turk.), 1927 P.C.I.J. (ser. A) No. 10 (Sept. 7).

360. Id. at 19. It is worth noting that neither the Permanent Court (which was, of course, far from permanent) nor the present-day ICJ has ever had authority to liquidate the meaning of international law. Article 59 of the ICJ's statute provides that "[t]he decision of the Court has no binding force except as between the parties and in respect of that particular case." Statute of the Int'l Court of Justice, Art. 59, available at http://www.icj-cij.org/documents/?p1=4\& 
"leaves them in this respect a wide measure of discretion, which is only limited in certain cases by prohibitive rules. ${ }^{{ }^{661}}$ Further, Sloss denies that there is "any rule of international law that prohibits domestic courts from exercising jurisdiction over foreign-cubed cases. To the contrary, the universality principle is a widely accepted principle of international law that authorizes States to apply their laws extraterritorially to address heinous conduct that violates universal human rights norms." ${ }^{362}$

This overstates the case considerably. First, Professor Sloss conflates the sort of extraterritoriality at issue in Kiobel with the broader meaning of that term in both international law and American statutory construction. In general discussions, extraterritoriality can entail any application of a state's law to conduct occurring outside its borders. That includes jurisdiction asserted over actions by a state's own citizens abroad (nationality), extraterritorial actions causing impacts within a state's borders (protective principle), and actions harming the state's citizens abroad (passive-personality principle). ${ }^{36}$ Acceptance of these sorts of extraterritoriality in international law, such as it is, would hardly establish the legitimacy of foreign-cubed cases like Kiobel. Those cases rely on the distinct principle of universal jurisdiction.

Likewise, Professor Sloss exaggerates by asserting that "the universality principle is a widely accepted principle of international law." Accepted by whom? Sloss cites the Restatement (Third), ${ }^{364}$ which

p2=2\&p3=0\#CHAPTER_III (last visited Feb. 4, 2015). According to Sir Ian Brownlie, this provision "reflects a feeling on the part of the founders that the Court was intended to settle disputes as they came to it rather than to shape the law." BROWNLIE, supra note 25, at 20; see also id. (noting that Article 51 was meant "to rule out a system of binding precedent"). Although such decisions undoubtedly do have "a role in the progressive development of the law," id. at 21, Brownlie notes that the Lotus decision itself was decided on a narrow vote and "was rejected by the International Law Commission in its draft articles on the law of the sea," $i d$. Generally speaking, ICJ decisions are one source among many in settling the meaning of international law-to the extent that it can be settled at all.

361. S.S. Lotus (Fr. v. Turk.), supra note 359; see also Dan E. Stigall, International Law and Limitations on the Exercise of Extraterritorial Jurisdiction in U.S. Domestic Law, 35 HASTINGS INT'L \& COMP. L. REV. 323, 331 (2012) (noting that the ICJ has reaffirmed this view as recently as 2009).

362. Sloss, supra note 238 , at 3.

363. See supra text accompanying notes $28-30$.

364. See Sloss, supra note 238, at 3 (citing RESTATEMENT (THIRD), supra note 22, $\$ 404 \mathrm{cmt}$. a \& b). Justice Breyer similarly invoked this Restatement section in Kiobel. See 133 S. Ct. at 1673 (Breyer, J., concurring in the judgment). Relying on the Restatement (Third) is problematic not just because it has been criticized as more normative than descriptive, see supra notes 135-36, but also because its function is not to restate international law or to survey other states' practice. 
establishes that universal jurisdiction is accepted by a certain segment of the American legal academy, and an article by two leading international advocates of universal jurisdiction. ${ }^{365}$ Maximo Langer has demonstrated, however, that universal jurisdiction is practiced only by a handful of Western European countries, each of which has taken steps to limit its exercise. ${ }^{366}$

Moreover, as I elaborate in the next two subsections, the United States is the only nation to exercise the sort of freestanding civil-side universal jurisdiction at issue in Kiobel and other foreign-cubed cases. ${ }^{367}$ Given the extremely mixed track record of such suits, it is hard to say that civil universal jurisdiction was well established in American state practice even before Kiobel. Notwithstanding Justice Breyer's assertion in his Sosa concurrence that a "procedural consensus exists" in favor of universal jurisdiction, ${ }^{368}$ much of the international academic commentary continues to treat universal jurisdiction as controversial. ${ }^{369}$

Moreover, the Restatement (Third) was promulgated over a quarter century ago, before significant retreats from universal jurisdiction in the countries that had practiced it. See supra note 71 and accompanying text.

365. See Sloss, supra note 238, at 3 (citing Donovan \& Roberts, supra note 9). Those advocates acknowledge that "state practice endorsing the exercise of universal jurisdiction" is "embryonic," but they assert that it is "beginning to emerge." Donovan \& Roberts, supra note 9, at 153. The Donovan and Roberts article stops far short of asserting, as Professor Sloss does, that universal civil jurisdiction is "well established." Sloss, supra note 238, at 3.

366. See Langer, supra note 32, at 43 (observing that universal jurisdiction is "applied essentially by Western European and developed Commonwealth states"); see also Yee, supra note 69, at 529-30 (Chinese scholar contesting general acceptance of universal jurisdiction).

367. See Anderson, supra note 104, at 166 ("Foreign parties don't regard the ATS as legitimate or as implementing genuine international law, and won't ever-not our close friends and allies, let alone China or Russia. Even the Canadians resent it.").

368. Sosa v. Alvarez-Machain, 542 U.S. 692, 762 (Breyer, J., concurring in part and in the judgment). In support, Justice Breyer cited only the Restatement (Third), a report of the International Law Association, a decision by the International Criminal Tribunal for the Former Yugoslavia (ICTY), and the Supreme Court of Israel's decision in the Eichmann case.

369. See supra text accompanying notes 86-104; see also IBA Task Force, supra note 357, at 151 ("The proper scope and application in certain instances or with regard to certain crimes of universal jurisdiction is controversial among states and among commentators."). One might also consider the international-law rationale as a descriptive canon: Courts should assume that Congress, as an empirical matter, generally wishes to comply with international law. To the extent that we deal with the intent of the enacting Congress-as seems appropriate with descriptive canons - then the relevant state of international law would be that law as it stood in 1789. Although the eighteenth-century world does seem to have recognized universal jurisdiction over pirates, everyone agrees that extraterritorial jurisdiction was more tightly circumscribed during this period. 
Even in its broader sense, extraterritoriality remains exceptional. According to a leading treatise, "The starting-point in this part of the law is the proposition that, at least as a presumption, jurisdiction is territorial. ${ }^{370}$ The exercise of extraterritorial jurisdiction does appear to be on the rise, but a recent report by the International Bar Association concluded that " $[\mathrm{t}]$ he steady increase in states exercising extraterritorial jurisdiction has not ... resulted in an abatement of the controversies surrounding such exercises." ${ }^{371}$ An interpretive canon presuming that statutes do not apply extraterritorially thus fits rather well with the current state of international law, which occasionally permits the exercise of extraterritorial jurisdiction but finds that jurisdiction both unusual and controversial.

2. Political Control of Foreign Policy and the Leap from Criminal- to Civil-Side Universal Jurisdiction. As discussed in Part I, the primary difference between American exercise of universal jurisdiction under the ATS and foreign practice is that the latter exists as part of the criminal law. Justice Breyer suggested in Sosa that "consensus as to universal criminal jurisdiction itself suggests that universal tort jurisdiction would be no more threatening. ${ }^{, 373}$ But as he acknowledged, the exercise of universal jurisdiction in other countries is nearly always public - that is, it is initiated and controlled by public officials rather than by private litigants. When private litigants do play a role, they are subject to significant public controls. ${ }^{374}$ Public domination of universalist litigation ensures that the same institutions responsible for the conduct of foreign policy have the ultimate say over the initiation and prosecution of international human-rights litigation.

370. BROWNLIE, supra note 25, at 298, 301.

371. IBA Task Force, supra note 357, at 5. For a sampling of the controversy, see, e.g., Kathleen Hixson, Note, Extraterritorial Jurisdiction Under the Third Restatement of Foreign Relations Law of the United States, 12 FORDHAM INT'L L.J. 127 (1988) (arguing that the Restatement (Third)'s relaxation of limits on extraterritoriality was inconsistent with international law).

372. See supra Section I.A.3. See also Macedo, supra note 66, at 11 (worrying that "[t]he currently incoherent jurisprudence of universal jurisdiction is likely to result in confusion and, at best, uneven justice").

373. Sosa v. Alvarez-Machain, 542 U.S. 692, 762 (Breyer, J., concurring in the judgment); see also Kiobel, 133 S. Ct. at 1676-77 (Breyer, J., concurring in the judgment) (analogizing ATS litigation to foreign countries' exercise of universal criminal jurisdiction).

374. See supra notes 50-51 and accompanying text. 
Intuitively, the civil nature of universal jurisdiction under the ATS may seem to render such jurisdiction less troubling; the Restatement, for example, suggests that "the exercise of criminal (as distinguished from civil) jurisdiction in relation to acts committed in another state may be perceived as particularly intrusive." ${ }^{375}$ That may well be true from the standpoint of the defendant and perhaps the defendant's state, although I argue in Subsection 3 that the exceptional characteristics of the American civil-justice system may create unique frictions. Other commentators blur the distinction between civil and criminal remedies, noting that international criminal law has increasingly provided for reparations and urging that compensation for victims should be recognized as part of the "effective remedy" that state parties must provide when they violate international human-rights treaties. ${ }^{376}$ And still other commentators even go so far as to say that accepting universal criminal jurisdiction requires civil jurisdiction a fortiori. ${ }^{37}$

But there are also good reasons to find the ATS's civil regime more troubling than criminal instances of universal jurisdiction. ${ }^{378}$ As Professors Bradley and Goldsmith have observed, "[w]hether in the civil or criminal context, one nation's examination of the validity of another nation's human rights record directly implicates international relations. In the criminal extradition or prosecution context, however, the executive branch has the duty, expertise, and discretion to accommodate such foreign relations concerns." "379 In civil cases, however, "human rights litigation is under the control of private plaintiffs, many of whom are noncitizens, and unelected judges." ${ }^{380}$

375. RESTATEMENT (THIRD), supra note $22, \S 403$ Reporters' Note 8.

376. See Donovan \& Roberts, supra note 9, at 153-54 (concluding that "the acceptance of universal criminal jurisdiction should carry over to the exercise of universal civil jurisdiction for at least the same range of conduct").

377. See LUC REYDAMS, UNIVERSAL JURISDICTION: INTERNATIONAL AND MUNICIPAL LEGAL PERSPECTIVES 3 (2003) (arguing that the "greater" power to prosecute criminally necessarily includes the "lesser" power to impose civil liability); but see Bradley, Universal Jurisdiction, supra note 10, at 343-46 (observing that "the theory of universal jurisdiction hypothesizes that each nation is delegated the authority to act on behalf of the world community, not on behalf of the particular victims. . . To the extent that private civil causes of action are designed primarily to redress harm to particular victims, they may be conceptually outside of the universal jurisdiction authority").

378. See Bradley, Universal Jurisdiction, supra note 10, at 343-46.

379. Bradley \& Goldsmith, Pinochet, supra note 167, at 2158-59.

380. Id. at 2159; see also Morris, supra note 59, at 356-57 (urging that because universalist prosecutions may precipitate international conflict, it is "imperative that high-level executive decision-makers, duly informed by intelligence and analysis from foreign ministries, have the 
One would expect the exercise of prosecutorial discretion to bring decisions to initiate proceedings at least somewhat in line with the Executive branch's foreign policy; executive officials could then be held politically accountable for their exercise of that discretion. Under the ATS, however, "private litigants make the decisions regarding when to bring these lawsuits, which countries to target, and what relief to seek." ${ }^{\prime 31}$

Other legal systems do allow somewhat more involvement by victims in the prosecutorial process, ${ }^{382}$ and in fact some of the most high-profile universalist prosecutions-including the Spanish case against Augusto Pinochet-have been initiated by private parties. ${ }^{383}$ Generally speaking, however, private involvement in criminal prosecutions overseas pales in comparison to the autonomy of the American private civil plaintiff (or her lawyers). The Pinochet case, for example, involved a civil-law jurisdiction in which the presiding judge took the lead in conducting the investigation. ${ }^{384}$ Moreover, universalist criminal prosecutions initiated by nongovernmental actors have been controversial for precisely this reason. ${ }^{385}$ Notably, in Belgium, criticism of such prosecutions by other states led Belgium largely to repeal its universal-jurisdiction statute. ${ }^{386}$

power to preclude prosecutions that could lead to international catastrophe"). As Professors Bradley and Goldsmith note, the British Law Lords "expressly encouraged Britain's home secretary to reconsider his decision to allow extradition proceedings against Pinochet to go forward, even though the Law Lords had determined that there was a valid legal basis to proceed with extradition." Bradley \& Goldsmith, Pinochet, supra note 167, at 2159. Although the secretary demurred, "[h]is decision . . . was based on just the sort of balancing of legal and political considerations ... that is not available in private civil litigation." Id.

381. Bradley \& Goldsmith, Pinochet, supra note 167, at 2181-82.

382. See supra notes 48-49 and accompanying text; see also Stephens, Translating Filártiga, supra note 20 , at 12 .

383. See Wilson, supra note 48 , at 3 . The Spanish acción popular allows individuals with an interest in a case or acting on behalf of a victim to bring private prosecutions. See C.E. art. 125, B.O.E. n. 311, Dec. 29, 1978 (Spain); Organic Law on the Judiciary art. 20.3 (B.O.E. 6/1985); L.E. Crim. § 101, 270.

384. See Wilson, supra note 48, at 3; see also Langer, supra note 32, at 33-34 (discussing “people's prosecutions" in Spain).

385. See Donovan \& Roberts, supra note 9, at 155.

386. See Steven R. Ratner, Belgium's War Crimes Statute: A Postmortem, 97 AM. J. INT'L L. 888, 896-97 (2003). Likewise, Britain has sharply curtailed the ability of private parties to initiate universal-jurisdiction prosecutions. See John Bellinger, Britain Amends Universal Jurisdiction Law, LAWFARE (Sept. 19, 2011), available at http://www.lawfareblog.com/ 2011/09/britain-amends-universal-jurisdiction-law ("Britain amended its universal jurisdiction law last week to require private individuals who seek arrest warrants for foreign government officials for human rights offenses to obtain the consent of Britain's director of public prosecutions."). 
A second functional consideration is that the underlying law in criminal proceedings is generally statutory. Most analogous prosecutions invoking universal jurisdiction have occurred in civil-law countries where statutes play a more prominent role. ${ }^{387}$ Even in this country, which has a rich common-law tradition on the civil side, the criminal law has been a statutory preserve since the early Republic. ${ }^{388}$ This tendency stems from separation-of-powers concerns about judicial power and due-process concerns about the vagueness of common-law crimes. Although judge-made law continues to play a role in federal criminal law, ${ }^{389}$ it remains the case that, by making human-rights violations a matter of civil tort rather than crime, the ATS commits this American version of universal jurisdiction to a judge-driven rather than a legislature-driven regime. ${ }^{39}$

This separation-of-powers choice has several consequences. It divorces not just the decision to prosecute, but also the development of the law's underlying content, from the political institutions also charged with formulating American foreign policy. A consequence for potential defendants concerns fair notice: it is far harder to anticipate how judges may develop the vast corpus of customary principles and open-ended human-rights treaties ${ }^{391}$ than to consult a statutory codification of prohibited conduct, even if the latter may inevitably retain some ambiguities around the edges.

Decoupling private civil litigation from executive foreign policy is not without its virtues. As Gary Bass has noted, states are unlikely to incur the political and logistical costs of universalist prosecutions pursued out of a disinterested concern for the international rule of law; rather, the states bringing such prosecutions will tend to be

387. Likewise, the Canadian universal-jurisdiction statute refers specifically to the definitions of genocide, crimes against humanity, and war crimes in the Rome Statute. See Crimes Against Humanity and War Crimes Act, S.C. 2000, c.24, $\$ 4$ (Can.).

388. See United States v. Hudson \& Goodwin, 11 U.S. (7 Cranch) 32, 36 (1812) (holding that before federal authorities may impose criminal penalties, "[t]he legislative authority of the Union must first make an act a crime, affix a punishment to it, and declare the Court that shall have jurisdiction of the offense"); see also Stewart Jay, Origins of Federal Common Law: Part One, 133 U. PA. L. REV. 1003, 1040 (1984); Stewart Jay, Origins of Federal Common Law: Part Two, 133 U. PA. L. REV. 1231, 1280 (1985).

389. See, e.g., Dan Kahan, Lenity and Federal Common Law Crimes, 1994 SUP. CT. REV. 345, 347-48; HART \& WECHSLER, supra note 188, at 689-90.

390. More recent enactments like the Torture Victim Protection Act (TVPA), by contrast, retain a civil model but define the content of the underlying law in the statute. See Torture Victim Protection Act, Pub. L. No. 102-256, Mar. 12, 1992, 106 Stat. 73.

391. See, e.g., Kelly, supra note 164, at 451 (emphasizing the indeterminacy of CIL). 
states-like Israel in the Eichmann case-that have suffered somehow at the hands of the accused, or states that have a political agenda to advance against another state ${ }^{392}$ Private plaintiffs initiate ATS litigation in American courts for strategic reasons of their own, of course, but at least the claims are adjudicated by the courts of a government that will often have little direct interest in the outcome. Advocates of universal civil jurisdiction have argued that keeping control of criminal sanctions in public hands while dispersing control of civil sanctions strikes the right balance. ${ }^{393}$ But the clear message of the Court's implied-rights jurisprudence is that this balance in itself is a question best left to Congress. ${ }^{394}$

Finally, it may be possible to modify the ATS regime in ways that would inject a degree of executive foreign-policy supervision. Although the implied-rights cases recognize judicial authority to make such modifications as a matter of federal common law, we are better off if courts need not guess at the political branches' preferences. In the Court's previous extraterritoriality cases, the presumption has often proved to be an effective "preferenceeliciting" rule; in both $A R A M C O$ and Morrison, for example, Congress responded to the Court's rejection of extraterritorial reach by restoring some of that reach but, at the same time, fine-tuning the statute's extraterritorial application in various ways. ${ }^{395}$ The specifics of how that might be done are outside the scope of this Article, but it is a mistake to assume that courts must bear sole responsibility for reform in this area.

3. America's Exceptional Civil-Justice System. The shift from a predominantly criminal form of universal jurisdiction in other countries to a civil form under the ATS also exacerbates the possibility of clashes between domestic and foreign law. In particular,

392. See Bass, supra note 63 at 78.

393. See Donovan \& Roberts, supra note 9, at 156 ("If the recognition of universal jurisdiction necessarily entails a balancing of traditional sovereign prerogatives and fundamental human values, the balance should be struck by according those with the greatest incentive to pursue reparations - that is, the victims of the heinous conduct - the right to do so in civil actions, while reserving to public authorities the decision to seek penal sanctions.").

394. See Bush v. Lucas, 462 U.S. 367, 389 (1983) ("Congress is in a far better position than a court to evaluate the impact of a new species of litigation ....").

395. See Curtis A. BRAdLEy \& JACK L. GOLdSMith, Foreign RELATIONS LAW: CASES AND MATERIALS 104-05 (5th ed. 2014) (discussing Congress's response to ARAMCO and Morrison); EINER ElHauge, STATUtORy DeFAult Rules: How TO INTERPRET UNCLEAR LEGISLATION 205-06 (2008) (discussing preference-eliciting rules of statutory construction). 
it brings into play the highly exceptional features of the American civil-justice system. ${ }^{396}$ Many features of that system are highly attractive to plaintiffs. ${ }^{397}$ But those features are also likely to strike foreign defendants as unusual and possibly unjust. Wholly apart from the substance of the particular claims advanced in ATS litigation, then, the process of American civil litigation may well amplify the discomfort that exercising universal jurisdiction in American courts inspires in foreign observers. ${ }^{398}$

Even within our own legal system, "[c]ivil litigation and criminal litigation... occupy separate worlds. They employ different procedural rules, often before different judges in different courthouses, and with almost entirely unconnected bars ...."399 These separate worlds differ in the degree to which they diverge from the rest of the world. ${ }^{400}$ Although American criminal prosecutions differ in significant ways from foreign prosecutions, American "exceptionalism" seems markedly more pronounced on the civil side. And although comparisons often emphasize differences between America and the civil-law countries, "American procedure is very different from its common law kin" as well. ${ }^{401}$

In Kiobel, the governments of Great Britain and the Netherlands filed two amicus briefs objecting "to the efforts of U.S. litigators and

396. See, e.g., Oscar G. Chase, American "Exceptionalism" and Comparative Procedure, 50 AM. J. Comp. L. 277, 287 (2002); Scott Dodson \& James M. Klebba, Global Civil Procedure Trends in the Twenty-First Century, 34 B.C. INT'L \& COMP. L. REV. 1, 2 (2011) (accepting the "holistic assessment that U.S. civil procedure is highly exceptionalist when compared to the civil law systems in the rest of the world," but arguing that "American exceptionalism' is diminishing in some, if not most, areas of civil procedure"); Richard L. Marcus, Putting American Procedural Exceptionalism into a Globalized Context, 53 AM. J. COMP. L. 709, 709-10 (2005) [hereinafter Marcus, Procedural Exceptionalism].

397. See Stephens, Translating Filártiga, supra note 20, at 27-34; Roger Alford, Arbitrating Human Rights, 83 NOTRE DAME L. REV. 505, 508-09 (2008).

398. See Hufbauer \& Mitrokostas, supra note 10, at 47; see also Marcus, Procedural Exceptionalism, supra note 396, at 710 (invoking "the nasty aroma American litigation seems to elicit in much of the rest of the world").

399. Sklansky \& Yeazell, supra note 226, at 684.

400. As David Sklansky and Stephen Yeazell have pointed out, the civil and criminal worlds also differ in the degree to which they have changed since the early Republic. See id. at 737 ("Criminal procedure . . . is frozen roughly into the shape it had in 1800 . . . By contrast, civil procedure['s] ... shape and general features would scarcely be recognizable to a lawyer from the early Republic."). This further undermines any attempt to derive a coherent civil-side regime for human-rights enforcement from the text and history of the first Judiciary Act.

401. Scott Dodson, Comparative Convergences in Pleading Standards, 158 U. PA. L. REV. 441, 442 (2010); see also Chase, supra note 396, at 284 (observing that "the American dispute process ... is exceptional even when measured against its siblings in the common law family"). 
judges to bypass the legal systems of other sovereigns by deciding civil cases involving foreign parties where there is no significant nexus to the U.S." ${ }^{402}$ These briefs emphasized that conflict with foreign nations over ATS suits arises in part because the United States "provide[s] a unique plaintiff-favoring system." "[T]he attractiveness of the United States as a forum for foreign plaintiffs is well known," the foreign governments argued, "and [it] may, in part, be traced by decisions by the United States to accord private plaintiffs a set of advantages that most other countries have not accepted." ${ }^{404}$ Those governments cited six "special litigation advantages available in the U.S.": the "American rule" that each side bears its own costs (including attorneys' fees); the breadth and expense of American discovery in civil cases; the constitutional right to a civil jury trial; the availability of punitive damages; broad "opt out" class actions; and the use of results-based contingent fees. ${ }^{40 .}$

Each of these features is a staple of the literature on comparative civil procedure. ${ }^{406}$ That literature also emphasizes American rules of notice pleading, which Scott Dodson has described as "unlike any other in the world." 407 Some scholars have identified modest trends

402. Brief of the Governments of the K. of the Netherlands and the U.K. of Great Britain and N. Ireland as Amici Curiae in Support of Neither Party at 24, Kiobel v. Royal Dutch Petroleum Co., 132 S. Ct. 1659 (2013) (No. 10-1491) (filed June 13, 2012) [hereinafter Netherlands \& Great Britain Brief]; see also Great Britain \& Netherlands Brief, supra note 17, at 29-33.

403. Great Britain \& Netherlands Brief, supra note 17, at 33; see also Netherlands \& Great Britain Brief, supra note 402, at 26-30.

404. Great Britain \& Netherlands Brief, supra note 17, at 33.

405. Id. at 27-28.

406. See, e.g., Linda S. Mullenix, Ending Class Actions As We Know Them: Rethinking the American Class Action, 64 EMORY L.J. 399, 401 (2014) (observing that class actions are "a central feature of American procedural exceptionalism," "resisted (if not rejected) by most foreign legal systems"); James R. Maxeiner, The American "Rule": Assuring the Lion His Share, in Cost and Fee Allocation in Civil Procedure: A Comparative Study 287 (Mathias Reimann ed., 2013) (decrying American failure to adopt a "loser pays" rule for attorney fees or to regulate fee agreements); John Y. Gotanda, Charting Developments Concerning Punitive Damages: Is the Tide Changing?, 45 COLuM. J. TRANSNAT'L L. 507, 510, 513-16 (2007) (observing that most civil-law countries "prohibit punitive damages in private actions because they consider punitive damages a form of punishment that is appropriate only in criminal proceedings"); Chase, supra note 396, at 288-96 (discussing civil juries and discovery as aspects of American exceptionalism).

407. Dodson, supra note 401, at 443; see also id. (explaining that "civil law countries... require detailed fact pleading and often evidentiary support at the outset, and . . . even most common law traditions . . . also require some fact pleading"; American pleading, by contrast, generally requires only "'a short and plain statement of the claim"” and "has traditionally focused on notice rather than facts" (quoting FED. R. CIV. P. 8)). 
toward convergence, particularly in pleading and aggregate-litigation procedures, but important and contentious differences remain. ${ }^{408}$ Foreign critics have argued, moreover, that these features compound one another in practice. Broad discovery increases litigation costs, which then cannot be recovered by prevailing defendants thanks to the American rule on attorneys' fees. ${ }^{409}$ Likewise, aggregate litigation and punitive damages magnify defendants' exposure to possibly capricious jury verdicts. ${ }^{410}$ And notice pleading, the lack of feeshifting, and contingent-fee arrangements all work together to enhance incentives to file claims. ${ }^{411}$

The exceptional features of American civil litigation reflect a litigation culture starkly different from that found elsewhere. The point is not simply that, as Anne-Marie Slaughter and David Bosco have observed, "[t]wenty-first-century America is one of the most litigious societies the world has ever known." ${ }^{412}$ Rather, American litigation differs from that abroad both with respect to who drives it and to the purposes that it seeks to achieve. Many have observed that American litigation elevates the parties and their lawyers over the judge. ${ }^{413}$ The parties frame the issues and control fact-gathering in American courts, for example, while judges tend to guide both processes elsewhere. ${ }^{414}$ Lawyer-driven litigation also feeds an

408. See, e.g., id. (arguing that the Supreme Court's decisions in Bell Atlantic Corp. v. Twombly, 550 U.S. 544 (2007), and Ashcroft v. Iqbal, 556 U.S. 662 (2009), brought American pleading closer to the rest of the world, but concluding that American practice remains "significantly different from foreign models"); Richard A. Nagareda, Aggregate Litigation Across the Atlantic and the Future of American Exceptionalism, 62 VAND. L. REV. 1, 6 (2009) ("European receptiveness to new procedures for aggregate litigation ... stops markedly short of full-fledged embrace for U.S.-style class actions, much less related features of litigation finance.").

409. See Netherlands \& Great Britain Brief, supra note 402, at 27.

410. Id. at 27-28; see also Richard Marcus, 'American Exceptionalism' in Goals for Civil Litigation, in GOALS OF CIVIL JUSTICE AND CIVIL PROCEDURE IN CONTEMPORARY JUdICIAL SySTEMS 123, 134 (Alan Uzelac ed., 2014) [hereinafter Marcus, Goals] ("One major feature of American litigation is that the stakes are higher.").

411. See Netherlands \& Great Britain Brief, supra note 402, at 27-28.

412. Anne-Marie Slaughter \& David Bosco, Plaintiffs' Diplomacy, 79 ForeIGN AfF. 102, 102 (2000).

413. See, e.g., Marcus, Procedural Exceptionalism, supra note 396, at 723-24 (contrasting the adversary and inquisitorial systems); Maxeiner, supra note 406, at 290 ("That private lawyers are the driving force behind civil justice explains the existence of the American practices of no indemnity for attorneys' fees and unregulated fee agreements.").

414. See Sklansky \& Yeazell, supra note 226, at 694 (observing that the power of private lawyers in our system "to compel sworn testimony and to require the other party and unaffiliated witnesses to disclose information and documents . . is broader and deeper than the 
"entrepreneurial spirit that has developed within the civil litigation bar." ${ }^{\prime 15}$ Second-wave Filártiga suits against corporate aiders and abettors are, of course, an example of that spirit. The independence of the bar from government, however, heightens the potential disconnect between ATS litigation and national foreign policy.

The most distinctive element of American litigation culture is its vibrant tradition of public-policy reform through litigation. ${ }^{416}$ This tradition, which places international human-rights lawyers in the role of Thurgood Marshall in Brown v. Board of Education, ${ }^{417}$ makes civil litigation a more instinctive strategy for human-rights advocates in this country. ${ }^{418}$ And facilitating reformist litigation may explain our system's plaintiff-friendly rules; as Richard Marcus has argued, "[t]he more one conceives of private litigation as furthering a public enforcement purpose, the more one may be tempted to provide incentives to pursue it, and the more one may be inclined to equip those who do pursue litigation with the tools they will need to succeed." ${ }^{\text {"19 }}$ Conversely, "[t]he absence of a comparable private enforcement goal helps explain why the procedures of the rest of the world differ so markedly from America's. ${ }^{, 420}$

Adoption of a civil-litigation model under the ATS thus promotes vindication of human rights through a mechanism that is out of step with practices in the rest of the world. This may or may

powers exercised by private lawyers in any other legal system"; in civil-law countries, by contrast, "judges typically decide whether and how deeply to probe the disputed facts"); see also Marcus, Procedural Exceptionalism, supra note 396, at 723-24 (comparing the role of the judge in the American system with the German, Japanese, and English systems). Here, too, there are some signs of modest convergence. See Dodson \& Klebba, supra note 396, at 14-18.

415. Sklansky \& Yeazell, supra note 226, at 693.

416. Stephens, Translating Filártiga, supra note 20, at 24-26. Some attribute this aspect of American legal culture to American suspicion of intrusive government, see generally ROBERT A. Kagan, Adversarial Legalism: The American Way of LAW (2001), while others emphasize the common-law tradition, see Marcus, Goals, supra note 410, at 130 ("The very heart of the common law system contemplates that the courts themselves will develop and enforce-via private litigation - the sorts of legal protections that are ordinarily adopted by legislative or administrative action in other legal systems.").

417. Brown v. Bd. of Educ., 347 U.S. 483 (1954); see, e.g., Koh, Transnational Public Litigation, supra note 1, at 2366 (explicitly invoking comparisons with Brown).

418. See, e.g., KAGAN, supra note 416, at 15-16 (suggesting that "in the United States lawyers, legal rights, judges and lawsuits are the functional equivalent of the large central bureaucracies that dominate governance in high tax, activist welfare states").

419. Marcus, Goals, supra note 410, at 133; see also Paul Carrington, Renovating Discovery, 49 ALA. L. REV. 51, 54 (1997) (claiming that private civil "discovery is the American alternative to the administrative state").

420. Marcus, Goals, supra note 410, at 140. 
not be a good thing-I tend to be a fan of the American model of civil litigation, but my purpose here is neither to praise that model nor to bury it. Instead, I want to make two more modest points. The first is that by transforming the universal criminal jurisdiction practiced in the rest of the world into a civil phenomenon, the Filártiga model of ATS litigation significantly amplified the risk of conflict with other legal systems. Foreign governments and corporations are both uncomfortable and unfamiliar with the American civil-litigation system, and that exacerbates the political conflict inherent when American institutions intervene in their affairs. ${ }^{421}$

The second point, however, is that the use of civil litigation to push social reforms-and to vindicate basic notions of justice-taps into a fundamental aspect of American legal culture. This gives ATS litigation an intuitive appeal to American lawyers. Who among us, after all, would not pay good money to watch Joe Jamail depose Bashar al-Assad? To the extent that Filártiga litigation is a natural American analog of criminal prosecutions in foreign lands, we are unlikely to abandon it entirely.

Nonetheless, the exceptionalism of American civil procedure and remedies law, the incentives it creates for plaintiffs, and the international resentment it inspires all suggest the need for care with procedure and remedies in transnational public litigation. The contrast with Bivens is instructive. The Court created an implied right of action in response to two anomalies-the limitation of the general federal civil-rights statute, 42 U.S.C. $§ 1983$, to suits against state and local officers, and the existence of a longstanding common-law right of action for constitutional violations by federal officers in cases involving equitable relief but not damages. ${ }^{422}$ Bivens filled the resulting gap, and it made sense to apply the generally applicable civil rules to the new class of claims. In an important sense, then, Bivens normalized the law governing damages actions against federal officers by conforming it to well-established practice in closely related areas. Recognition of universal civil jurisdiction under Filártiga, however, introduced something entirely new and different into the international human-rights regime. And it exported, for the first time, the American tradition of reformist civil litigation beyond our own

421. It also makes civil-side litigation an odd choice if the point of having universal jurisdiction is to join in a common venture with other societies. Cf. Burley, supra note 7, at 493.

422. See Bivens v. Six Unknown Named Agents of the Fed. Bureau of Narcotics, 403 U.S. 388, 403 (1971); see also id. at 429 (Harlan, J., concurring). 
borders. Kiobel's retrenchment is likely just the beginning of a broader effort to rein in that development.

\section{Transnational Public-Law Litigation After KIOBEL}

Kiobel imposed an important limit on ATS claims, but it is hardly the end of the story. The Court did not explain its holding that ATS claims must "touch and concern the territory of the United States, ${ }^{, 423}$ and it left unresolved longstanding questions about whether ATS claims may be brought against aiders and abettors or corporate defendants. Section A of this Part considers what the Court's approach so far can tell us about these questions. Section B then turns to a broader set of issues about the future and structure of transnational public-law litigation. Throughout, I argue that the Court's experience with public-law litigation generally, and particularly the implication of private rights to sue, will (and should) inform its approach to international human-rights claims under the ATS.

\section{A. U.S. Defendants and the Unresolved Pre-Kiobel Questions}

In the wake of Kiobel, human-rights advocates sought a silver lining in the continuing possibility of litigation against American defendants. ${ }^{424}$ In addition to the Unocal case, a number of other prominent ATS actions have been brought against U.S. corporations. ${ }^{425}$ "A majority of these cases are against U.S. companies," noted one advocate, "and [Kiobel] still means they can be held accountable." ${ }^{226}$ As Oona Hathaway put it, after Kiobel " "[f]oreign cubed' cases ... are off the table. But there may remain significant scope for 'foreign squared' cases—cases in which the

423. Kiobel v. Royal Dutch Petroleum Co., 133 S. Ct. 1659, 1669 (2013).

424. See, e.g., Steinhardt, Short Drink, supra note 233, at 841 ("On closer analysis, however, Kiobel, like Sosa v. Alvarez-Machain before it, adopts a rhetoric of caution without foreclosing litigation that fits the Filártiga model.”). Other possibilities exist. For instance, Kiobel may not bar suits against foreign defendants based on foreign conduct that causes effects within the United States. See Vázquez, Presumptions, supra note 187, at 1737. I am not aware of any examples of such a suit.

425. See, e.g., Doe VIII v. Exxon Mobil Corp., 654 F.3d 11 (D.C. Cir. 2011); Bowoto v. Chevron Corp., 621 F.3d 1116 (9th Cir. 2010).

426. Quoted in Jonathan Stempel, Window Narrows in U.S. for Human Rights Abuse Lawsuits, REUTERS, Apr. 18, 2013, available at http://www.reuters.com/article/2013/04/18/ususa-court-humanrights-idUSBRE93H15O20130418. 
plaintiff or defendant is a U.S. national or where the harm occurred on U.S. soil." ${ }^{427}$

Foreign-squared suits are closer to the First Congress's likely purpose in enacting the ATS. As already discussed, recent scholarship has insisted that Congress intended to provide a remedy only for wrongs for which the United States might be held accountable under international law. That would include not only wrongs to aliens occurring within U.S. territory but also, in at least some circumstances, wrongs committed by American nationals abroad. ${ }^{428}$

ATS litigation against U.S. defendants will raise at least three sets of difficult questions. The first is the question raised by the Kiobel concurrences: Exactly how much contact with the United States is necessary to support a suit under the ATS? Such cases rely on nationality, not universality, as a basis for jurisdiction; they are thus less controversial than foreign-cubed cases as a matter of international law and practice. The presumption against extraterritoriality remains applicable, however. None of the Supreme Court's extraterritoriality cases before Kiobel, after all, involved universal jurisdiction. In $A R A M C O$, for example, the Court held that Title VII's prohibition on employment discrimination did not apply extraterritorially to a suit by an American national against a company incorporated in Delaware, because the events in question occurred in Saudi Arabia. ${ }^{429}$ Cases like ARAMCO suggest that the mere nationality of the defendant may not be enough to change Kiobel's result.

Early post-Kiobel decisions in the federal circuit courts bear out this prediction. In Al Shimari v. CACI Premier Technology, Inc. ${ }^{430}$ the Fourth Circuit held that an ATS claim by former detainees at the Abu Ghraib prison in Iraq against an American defense contractor sufficiently "touch[ed] and concern[ed]" the United States "to displace the presumption against extraterritorial application." The court of appeals did not think it sufficient that CACI was an American corporation; rather, it emphasized other connections to the United States, including allegations "that CACI's managers in the

427. Oona Hathaway, Kiobel Commentary: The Door Remains Open to "Foreign Squared" Cases, SCOTUSBLOG (Apr. 18, 2013, 4:27 PM), available at http://www.scotusblog.com/2013/04/ kiobel-commentary-the-door-remains-open-to-foreign-squared-cases.

428. See Bellia \& Clark, Two Myths, supra note 115, at 1638-40; Lee, Safe Conduct, supra note 117, at 891-92; Vázquez, Presumptions, supra note 187, at 1736.

429. See EEOC v. Arabian Am. Oil Co. (ARAMCO), 499 U.S. 244, 249 (1991).

430. Al Shimari v. CACI Premier Tech., Inc., 758 F.3d 516, 530 (4th Cir. 2014). 
United States gave tacit approval to the acts of torture committed by CACI employees at the Abu Ghraib prison, attempted to 'cover up' the misconduct, and 'implicitly ... encouraged' it." ${ }^{\text {,431 }}$ Moreover, CACI acted pursuant to a contract to perform interrogations with the U.S. government, and the alleged torture occurred at a United States military facility.

Al Shimari seems like a fairly easy case under Kiobel. ${ }^{433}$ The Eleventh Circuit, on the other hand, rejected an ATS claim in Cardona v. Chiquita Brands International, Inc. ${ }^{434}$ Cardona was a class action by Colombians alleging that the defendant, a U.S. corporation, made payments to paramilitary groups that carried out torture and extrajudicial killings. The court of appeals' terse opinion noted that " $[\mathrm{t}]$ here is no allegation that any torture occurred on U.S. territory, or that any other act constituting a tort in terms of the ATS touched or concerned the territory of the United States with any force. ${ }^{435}$ The majority implicitly rejected the dissent's argument that the case satisfied Kiobel simply because the defendant was an American national, and because plaintiffs alleged "that Chiquita's corporate officers reviewed, approved, and concealed payments and weapons transfers to Colombian terrorist organizations from their offices in the United States with the purpose that the terrorists would use them to commit extrajudicial killings and other war crimes." ${ }^{\text {"436 }}$

It seems premature to view Al Shimari and Cardona as a circuit split: the former presented a considerably more compelling case under Kiobel than the latter, and a court applying the same standard might well come out differently on these two sets of facts. At the same time, Cardona seems to have viewed allegations that the American corporate defendant's home office knew about and participated in the planning of rights violations abroad with more skepticism than did Al Shimari. It will always be possible to allege

431. Id. at 530-31.

432. See id. at 528, 530-31.

433. See John Bellinger, Two New ATS Decisions: Fourth and Eleventh Circuits Split on Whether Claims Against CACI and Chiquita "Touch and Concern" the Territory of the United States, LAWFARE (July 27, 2014, 8:53 PM) http://www.lawfareblog.com/2014/07/two-new-atsdecisions-fourth-and-eleventh-circuits-split-on-whether-claims-against-caci-and-chiquita-touchand-concern-the-territory-of-the-united-states ("Of the pending ATS cases, the CACI suit may present the most compelling factual scenario for the extraterritorial application of the ATS to a US corporation.").

434. Cardona v. Chiquita Brands Int'l, Inc., 760 F.3d 1185 (11th Cir. 2014).

435. Id. at 1191.

436. Id. at 1192, 1194 (Martin, J., dissenting). 
that sort of involvement, and if such allegations are sufficient to get plaintiffs past a motion to dismiss then Kiobel may not prove so severe a limit. The Supreme Court seems likely to apply its decisions raising the pleading bar to these sorts of claims, so that plaintiffs will need to plead specific facts demonstrating a plausible connection to U.S. territory. ${ }^{437}$

The second set of questions includes the laundry list of uncertainties about the ATS itself that predated Kiobel and were not resolved by that decision. These questions, like the extraterritoriality issue, are transsubstantive-they concern not the limits of actionable claims, but whether Sosa's right of action covers aiding-and-abetting liability or permits suits against corporations. Nonetheless, one way to handle these questions would be to treat them as identical to questions about Sosa's substantive scope-that is, corporate or aiding-and-abetting liability would be permitted only if international law provides for such liability with the same degree of clarity and universal acceptance required for the underlying substantive offense. Hence, defense counsel in ATS cases have tended to argue that international law governs all ancillary questions, probably because corporate liability is relatively scarce in international law. ${ }^{438}$ Plaintiffs (and sympathetic academics), on the other hand, have generally argued that federal common law governs these ancillary questions. ${ }^{439}$

I submit that both groups are partially correct; any Sosa claim should have to clear both an international- and a domestic-law bar. Sosa's cause of action is limited to claims that would fit within the ATS's grant of jurisdiction, which requires "a tort ... in violation of the law of nations." ${ }^{440}$ If international law does not recognize corporate liability, for example, that standard is not satisfied. But

437. See Ashcroft v. Iqbal, 556 U.S. 662 (2009) ("To survive a motion to dismiss, a complaint must contain sufficient factual matter, accepted as true, to 'state a claim to relief that is plausible on its face."' (quoting Bell Atlantic Corp. v. Twombly, 550 U.S. 544 (2007))); see also Twombly, 550 U.S. at 557 (rejecting "naked assertion[s]" without "further factual enhancement").

438. See, e.g., Brief for Respondents at 17-26, Kiobel v. Royal Dutch Petroleum Co., 133 S. Ct. 1659 (2013) (No. 10-1491) (arguing that whether corporations may be sued under the ATS is a question governed by international law). International law also arguably supports a relatively demanding standard for aiding-and-abetting liability. See id. at 50-51.

439. See, e.g., Brief for Petitioners, Kiobel v. Royal Dutch Petroleum Co., 133 S. Ct. 1659 (2013) (No. 10-1491), at 24-25 (arguing that "federal common law supplies the rules governing the scope of tort remedies in ATS litigation"); Casto, New Federal Common Law, supra note 23, at 641 (arguing that "[t]he norm that a defendant is alleged to have violated comes from international law, and domestic law supplies all other rules of decision").

440. 28 U.S.C. $\S 1350$ (2012). 
because the plaintiff's right to sue derives from federal common law, domestic-law limitations are relevant as well. That is evident from Kiobel itself, which looked to the domestic-law presumption against extraterritoriality to delimit Sosa's right of action-another ancillary question that Sosa left open.

The ancillary questions go away, of course, if one adopts Justice Scalia's conclusion in Sosa that "creating a federal command (federal common law) out of 'international norms,' and then constructing a cause of action to enforce that command through the purely jurisdictional grant of the ATS, is nonsense upon stilts." ${ }^{441}$ But no justice seemed interested in revisiting the existence of an implied right of action in Kiobel, even though it seems likely that at least four current Justices would embrace Scalia's view. ${ }^{422}$ In any event, the Court's unanimous rejection of both Sosa's and Kiobel's claims on the merits strongly suggests that all the Justices share a concern about the judicial lawmaking entailed by implied private rights of action. That consensus has been particularly evident in the Court's recent Bivens cases, in which even the liberal Justices have generally refused to extend the scope of that implied remedy. ${ }^{443}$

The Bivens cases make clear that the Court's hesitance about implied private rights of action extends not simply to their existence, but also to their scope. This is a critical point, because it presages a likely resolution of the remaining ancillary questions under the ATS. Even accepting Sosa's holding that an implied right exists under the ATS, the general presumption against implied rights will constrain the scope of that right. A similar pattern has occurred in the Court's statutory implied-rights jurisprudence. In Central Bank of Denver, N.A. v. First Interstate Bank of Denver, N.A. ${ }^{444}$ for example, the Court

441. Sosa v. Alvarez-Machain, 542 U.S. 692, 743 (2004) (Scalia, J., concurring in part and in the judgment).

442. For those keeping score at home, Justice Scalia wrote for himself, Chief Justice Rehnquist, and Justice Thomas in Sosa. Id. at 739. It seems likely that Scalia's position would garner at least four votes today, with Chief Justice Roberts voting the same as his predecessor and Justice Alito switching positions with Justice O'Connor, who joined Justice Souter's opinion in Sosa.

443. See, e.g., Minneci v. Pollard, 132 S. Ct. 617, 623 (2012) (rejecting, by an 8-1 vote, an effort to extend Bivens to cover an Eighth Amendment claim against employees of a privately operated federal prison); Wilkie v. Robbins, 551 U.S. 537, 548-49 (2007) (rejecting, by a 7-2 vote, a request to extend Bivens to cover harassment and intimidation by the Bureau of Land Management).

444. Cent. Bank of Denver, N.A. v. First Interstate Bank of Denver, N.A., 511 U.S. 164, 180 (1994). 
rejected calls to extend the implied private right of action under SEC Rule 10b-5 to aiders and abettors. The Court signaled its reluctance to extend nonstatutory causes of action, emphasizing, inter alia, that although Congress has enacted a general criminal aiding-and-abetting statute, there is no such statute on the civil side. ${ }^{445}$ More recently, Stoneridge Investment Partners, LLC v. Scientific-Atlanta, Inc. ${ }^{446}$ refused to extend the implied right under Rule 10b-5 to suits against entities who allegedly acted in concert with a company accused of issuing a misleading financial statement. The Court observed that "[c]oncerns with the judicial creation of a private cause of action caution against its expansion. The decision to extend the cause of action is for Congress, not for us. ${ }^{\$ 47}$

Cases like Central Bank of Denver and Stoneridge Partners suggest that further restrictions on the ATS right of action may be in the offing. Both cases refused to extend implied rights under the federal securities statutes to aiders and abettors. The Roberts Court may well make a similar call under the ATS, largely shutting down the second wave of Filártiga litigation and restricting ATS suits to actions against the actual perpetrators of human-rights violations. If Congress wished to curb private suits while preserving leverage to spur reform abroad, it might choose to replace private aiding-andabetting suits with a more public form of human-rights enforcement directed at multinational corporations, modeled on the Foreign Corrupt Practices Act (FCPA) ${ }^{48}$ Left to its own federal-common-law devices, however, the Supreme Court is likely to view with considerable skepticism each effort to expand Sosa's implied right of action to new situations or classes of defendants.

By locating the ATS within its implied-right-of-action jurisprudence, the Court tilted the playing field strongly against any expansion of ATS liability. On the other hand, the "special factors" discussed in the previous Part will be more mixed in cases against U.S. defendants. The potential for U.S. responsibility for international-law violations by American nationals provides a reason

445. Id. at $181-82$.

446. Stoneridge Inv. Partners, LLC v. Scientific-Atlanta, Inc., 552 U.S. 148, 152-53 (2008).

447. Id. at 165; see Va. Bankshares, Inc. v. Sandberg, 501 U.S. 1083, 1085, 1102 (1991) (stating, as a "fundamental principle[] governing recognition of a right of action implied by a federal statute," that "the breadth of the right once recognized should not, as a general matter, grow beyond the scope congressionally intended").

448. Foreign Corrupt Practices Act of 1977, Pub. L. No. 95-213, 91 Stat. 1494 (1977) (codified as amended at 15 U.S.C. $§ \$ 78 m, 78 d d-1,78 d d-2,78 d d-3$ (2012)). 
why ATS jurisdiction may actually further foreign-policy goals, and the concern about offending foreign nations by holding their corporations liable will be less substantial in these situations. Still, other factors may counsel caution. For example, broad availability of ATS jurisdiction against American corporations, even for actions taking place entirely abroad, may place those corporations at a competitive disadvantage vis-à-vis foreign corporations. ${ }^{449}$ And even litigation against U.S. companies may offend foreign governments to the extent that it brings embarrassing facts to light concerning their own human-rights abuses or threatens a business relationship upon which the foreign state depends. ${ }^{450}$

Finally, it is not at all clear to what extent Filártiga-style lawsuits against U.S. defendants will need to rely on the ATS at all. The ATS remains a jurisdictional statute, but aliens suing U.S. defendants will be able to get into federal court under the diversity statute. ${ }^{451}$ To be sure, those plaintiffs will still need a cause of action, and to the extent that they rely on the federal-common-law right of action recognized in Sosa, plaintiffs will have to accept the limits on that right of action identified in the Court's ATS case law. But Sosa is not the only possible right of action. For instance, the law of the place in which the injury occurred may provide a cause of action. Or plaintiffs may choose to sue under American state law-torture, extrajudicial killing, and rape are torts, after all. ${ }^{452}$ Indeed, human-rights plaintiffs may choose to avoid the federal jurisdictional questions altogether by suing in state courts. ${ }^{453}$

Each of these options would require American courts to decide whether the various limits on the Sosa cause of action are tied to the ATS or serve as freestanding limitations on any suit in an American court based on human-rights violations abroad. I consider those issues

449. See Anupam Chander, Unshackling Foreign Corporations: Kiobel's Unexpected Legacy, 107 AM. J. INT'L L. 829, 829 (2014).

450. See, e.g., Torres v. S. Peru Copper, 113 F.3d 540, 543-44 (5th Cir. 1997) (permitting removal of a case to federal court based on these sorts of concerns).

451. See 28 U.S.C. § 1332; Paul Hoffman \& Beth Stephens, International Human Rights Cases Under State Law and in State Courts, 3 U.C. IRVINE L. REV. 9, 12 (2013).

452. See, e.g., Doe v. Exxon Mobil, 654 F.3d 11, 71 (D.C. Cir. 2011) (holding that the district court had diversity jurisdiction over tort claims filed against Exxon by Indonesian citizens).

453. Childress, supra note 6, at 715; see also Christopher A. Whytock, Donald Earl Childress III \& Michael D. Ramsey, Foreword: After Kiobel-International Human Rights Litigation in State Courts and Under State Law, 3 U.C. IRVINE L. REV. 1 (2013) (introducing a symposium on the topic). 
in depth elsewhere. ${ }^{454}$ The remainder of the present discussion focuses instead on broader considerations about the enforcement of international law.

\section{B. The Broader Debate About Transnational Public-Law Litigation}

The ATS is not just any statute; it is, as Harold Koh and many others have suggested, the centerpiece for contemporary visions of transnational public-law litigation. ${ }^{455}$ At least some federal judges have read this mandate very broadly. Judge Jack Weinstein, for example, has written that "[i]n judging international human-rights claims against domestic corporations or others, courts in the United States with jurisdiction act as quasi international tribunals," applying an "international law of human rights [that] parallels and supplements national law, superseding and supplying the deficiencies of national constitutions and laws." ${ }^{, 456}$ For that reason, it is worth thinking about Kiobel and the ATS in light of broader debates about the structure of international-law enforcement.

One longstanding debate has concerned the choice between legal and political enforcement. Some critics of Filártiga-style litigation, for example, have argued that judicial resolution of human-rights claims gets in the way of efforts by the State Department and other public institutions to improve human-rights compliance around the world through diplomacy and action in supranational political organizations. ${ }^{457}$ This position harkens back to the long period when international human-rights law was largely aspirational. Legal enforcement mechanisms were minimal to nonexistent, and jurisprudes seriously debated whether international law was really "law" at all. ${ }^{458}$ Aspirational principles of human rights proved more efficacious than many observers expected during this period, ${ }^{459}$ but

454. See Ernest A. Young, After Kiobel: Legislative Reform of the Alien Tort Statute and the Migration of Human Rights Claims in American Courts (unpublished draft on file with author).

455. See text accompanying note 1, supra; see also Childress, supra note 6, at 712 ("[N]o other U.S. statute frames the issue of U.S. courts' application of international law so starkly.").

456. In re Agent Orange Prod. Liab. Litig., 373 F. Supp. 2d 7, 17 (E.D.N.Y. 2005) (quoting LORI FISLER DAMROSCH, LOUIS HENKIN, RICHARD CRAWFORD PUGH, OSCAR SCHACHTER \& HANS SMIT, INTERNATIONAL LAW: CASES AND MATERIALS 645 (4th ed. 2001)).

457. See Bellinger, supra note 13, at 8-10, 13-14; Ku \& Yoo, supra note 127, at 195-98.

458. See, e.g., H.L.A. HART, THE CONCEPT OF LAW 213-16 (2d ed. 1997) (1964) (arguing that international law is not law because it lacks a system of "secondary rules" for the creation, interpretation, and enforcement of primary rules of conduct).

459. See, e.g., JOHN LewIS GAdDIs, THE COLD WAR: A New HistORY 190-91 (2005) (describing the role of the Helsinki Accords, in which the Soviet Union agreed to abide by basic 
their effect remained largely political. International law provided an argument that could be employed in bilateral negotiations or in multilateral supranational organizations; sometimes it provided a rallying point for popular movements. But it was not ordinarily the sort of thing one could go to court and enforce.

Those days are fading now, and international human-rights law increasingly operates as law today. We are moving into a period in which the most interesting questions involve not the substantive content of human rights but rather questions of institutional design for enforcement. ${ }^{460}$ International courts have proliferated, and they increasingly demonstrate an ability to shape nations' behavior. ${ }^{461}$ And states face considerable informal pressures to comply even when not subject to sanctions or binding judgments. ${ }^{462}$ Legal enforcement does remain sporadic and often ad hoc in the absence of a centralized legal system at the international level. Experience with universal jurisdiction abroad suggests that courts must pick their spots carefully in order to be effective; prosecutions are most likely against former officials of defunct regimes who can no longer mobilize political blowback, and the need to make such pragmatic calculations poses its own difficulties for the international rule of law. ${ }^{463}$ But scholars continue to advance evidence that human-rights law does impose meaningful constraints on behavior. ${ }^{464}$

In this environment, it is both unrealistic and unnecessary to exclude an independent role for courts. An international rule of law

human-rights guarantees in what many perceived at the time as an empty gesture, in helping bring down Soviet communism).

460. See, e.g., Young, Institutional Settlement, supra note 231, at 1145-50; Jenny S. Martinez, Towards an International Judicial System, 56 STAN. L. REV. 429, 431-33 (2003); Laurence R. Helfer \& Anne-Marie Slaughter, Toward a Theory of Effective Supranational Adjudication, 107 YALE L.J. 273, 276-79 (1997).

461. See, e.g., ALTER, supra note 327, at 32-67.

462. See, e.g., Ryan Goodman \& Derek Jinks, How to Influence States: Socialization and International Human Rights Law, 54 DUKE L.J. 621, 635-55 (2004).

463. One may expect, for instance, an international version of the debate in American constitutional law over the legitimacy of the "passive virtues"- that is, doctrines by which courts avoid taking jurisdiction over disputes likely to damage their legitimacy. Compare ALEXANDER H. Bickel, The LeAst DANGerous BRANCH-The Supreme Court AT THE BAR OF POLITICS 127 (1962) (arguing in favor of these "passive virtues"), with Gerald E. Gunther, The Subtle Vices of the "Passive Virtues"-A Comment on Principle and Expediency in Judicial Review, 64 COLUM. L. REV. 1 (1964) (criticizing Bickel's view).

464. See, e.g., KATHRYN SikKINK, The Justice CAscade: How Human Rights Prosecutions are Changing World Politics (2011); Beth A. Simmons, Mobilizing FOR HUMAN Rights: INTERNATIONAL LAW IN DOMESTIC POLITICS (2009). 
has been a goal of American foreign policy since the Founding ${ }^{465}$ and the increasing judicialization of international affairs may be seen as a sign of that policy's success. In this vein, Tom Lee has argued that "an energetic role for the federal courts is fully consistent with the original meaning of the ATS. ${ }^{״ 466}$ Professor Lee points out that the federal judiciary historically served as a "safety valve" in foreignaffairs controversies. ${ }^{467}$ This point mirrors a recurrent theme in the evolution of foreign sovereign immunity and the act-of-state doctrine: sometimes it is helpful to American foreign relations to separate the dispute-resolution role of the courts from the foreign-policy role of the national executive. The key question is how to preserve this complementary role while minimizing judicial interference with foreign policy formulated by the political branches.

Once we concede some role to the courts, then human-rights enforcement raises at least two fundamental design questions. The first is the choice between public and private enforcement-that is, between enforcement initiated and controlled by government actors (or international organizations), on the one hand, and actions brought by private actors, principally victims but perhaps also other forms of "private attorneys general." Within the class of public enforcement, more-specific questions arise concerning control over the decision to prosecute. In some European countries, for example, individual judges have been empowered to bring universal-jurisdiction prosecutions largely outside the control of national executive authorities. ${ }^{468}$ Some of the more extravagant episodes in this vein have led to legislation consolidating executive control over such prosecutions. $^{469}$ Under the American FCPA, by contrast, prosecutorial authority is centralized not only within the federal Executive branch, but within a particular office at Main Justice. ${ }^{470}$

465. See, e.g., HERRING, supra note 15, at 69, 74 (noting the Washington administration's insistence on neutral rights during the conflict between Britain and France); Burley, supra note 7, at 481-88 (discussing the Founders' general concern with upholding the international rule of law).

466. Thomas H. Lee, The Three Lives of the Alien Tort Statute: The Evolving Role of the Judiciary in U.S. Foreign Relations, 89 NOTRE DAME L. REV. 1645, 1650 (2014).

467. Id. at 1657.

468. See, e.g., Langer, supra note 32 , at 5.

469. See id. at 10-41; Ratner, supra note 386, at 889-92.

470. See Mike Koehler, The Impact of Kiobel on FCPA Enforcement, OPINIO JURIS (Apr. 18, 2013, 9:30 AM), available at http://opiniojuris.org/2013/04/18/kiobel-insta-symposium-theimpact-of-kiobel-on-fcpa-enforcement. 
When public enforcement occurs at the supranational level, issues of accountability and control become considerably more formidable. ${ }^{471}$

The second choice is between enforcement by supranational or national institutions. Supranational enforcement may occur through permanent institutions, like the ICC; institutions created to deal with a particular situation, like the ad hoc International Criminal Tribunals for Rwanda (ICTR) and the former Yugoslavia (ICTY); or one-shot decisionmakers assembled to hear a particular dispute, such as the investor-arbitration panels convened under Chapter 11 of the North American Free Trade Agreement (NAFTA). ${ }^{472}$ Permanent institutions may be either human-rights specific, like the ICC, or general-purpose, like the ICJ. National enforcement may also occur through preexisting general-purpose institutions, such as the U.S. federal courts, or through special-purpose institutions, such as South Africa's Truth and Reconciliation Commission. At each level, moreover, proceedings may be judicial or administrative in nature, and in either case institutions may or may not have authority to make new law in addition to interpreting and enforcing preexisting legal principles. This is true even for courts: international courts modeled on the civil-law tradition formally eschew any lawmaking function by denying the authority to create binding precedent ${ }^{473}$ while American courts enjoy a robust tradition of common-law development of human-rights norms. ${ }^{474}$

As the chart below demonstrates, one can find examples of all four combinations of choice along these two dimensions:

471. See, e.g., Jenia Iontcheva Turner, Accountability of International Prosecutors, in LAW AND PRACTICE OF THE INTERNATIONAL CRIMINAL COURT (Carsten Stahn ed., forthcoming 2015), available at http://papers.ssrn.com/sol3/papers.cfm?abstract_id=2473778 [hereinafter Turner, Accountability].

472. Although most consider NAFTA to be part of international economic law, the right against expropriation of private property - the concern of NAFTA Chapter 11-is also recognized as a human right. See, e.g., JACK DONNELLY, UNIVERSAL HUMAN Rights IN THEORY AND PRACTICE 27, 43-44 (3d ed. 2013).

473. But see JOHN HENRY MERryMAN, THE CIVIL LAW Tradition: AN INTROdUCTION TO THE LEGAL SYSTEMS OF EUROPE AND LATIN AMERICA 46-47 (2d ed. 1985) (observing that in practice, the civil-law tradition is not as hostile to precedent as it is in theory).

474. See, e.g., District of Columbia v. Heller, 554 U.S. 570 (2008) (recognizing an individual right to bear arms); Roper v. Simmons, 543 U.S. 551 (2005) (invalidating the juvenile death penalty as "cruel and unusual punishment"); Lawrence v. Texas, 539 U.S. 558 (2003) (striking down laws banning homosexual sodomy); Griswold v. Connecticut, 381 U.S. 479 (1965) (recognizing a due-process right to privacy); Brown v. Bd. of Education, 347 U.S. 483 (1954) (holding that racially segregated schooling denies "equal protection of the laws"). 


\begin{tabular}{|l|l|l|}
\cline { 2 - 3 } \multicolumn{1}{c|}{} & $\begin{array}{l}\text { Supranational } \\
\text { Institutions }\end{array}$ & National Institutions \\
\hline Public Enforcement & $\begin{array}{l}\text { ICC } \\
\text { Ad Hoc Tribunals } \\
\text { (ICTY \& ICTR) }\end{array}$ & $\begin{array}{l}\text { Universal Criminal } \\
\text { FCPA }\end{array}$ \\
\hline Private Enforcement & $\begin{array}{l}\text { NAFTA Chapter 11 } \\
\text { Investor Arbitration }\end{array}$ & ATS Suits \\
\hline
\end{tabular}

This is not the place for a comprehensive evaluation of these options, and I do not contend that one combination is optimal in all circumstances. At least for the foreseeable future, the best approach is probably a fairly eclectic mix of all four options. The remainder of this Part identifies some more general considerations involved in making the relevant choices.

1. Supranational vs. National Enforcement. Some critics of universal jurisdiction have argued that prosecution of grave and universally condemned crimes under international law should be reserved to international courts. ${ }^{475}$ The high-profile work of the ICC, as well as the ICTR and ICTY, tends to obscure the overall rarity of supranational human-rights enforcement. ${ }^{476}$ These sorts of tribunals must often overcome political pushback and typically suffer from limited resources. ${ }^{477}$ Experience in Rwanda and the former Yugoslavia suggest that supranational tribunals may be an effective response to particularly egregious and high-profile human-rights atrocities, particularly when the perpetrating governments are politically isolated or defunct. ${ }^{478}$ More generally, Karen Alter has

475. See, e.g., Kissinger, supra note 53, at 92-95.

476. See generally DONNELLY, supra note 472, at 161 (emphasizing that "international human rights law creates a system of national implementation of international human rights") (emphasis added).

477. See Bibas \& Burke-White, supra note 40, at 671-73, 676-77; Payam Akhavan, Whither National Courts? The Rome Statute's Missing Half, 8 J. INT. CRIM. JUSTICE 1245, 1247 (2010) ("[B]ecause of the costly and time-consuming nature of international criminal justice, where national courts have failed to act, the ICC can only investigate or prosecute a small fraction of the perpetrators.").

478. See, e.g., Bibas \& Burke-White, supra note 40, at 647-48 (noting that supranational criminal courts have developed a model of justice and procedure narrowly focused on atrocities); Langer, supra note 32, at 9 (noting that Rwandans and former Yugoslavs were 
documented a remarkable expansion in the number and efficacy of international courts over the last half-century. ${ }^{479}$ But no one thinks that the international judiciary has developed the capacity to act as the primary enforcer of human rights. ${ }^{480}$ Assertions of universal jurisdiction by domestic courts developed largely in response to the weakness of supranational criminal enforcement, ${ }^{481}$ and that weakness seems likely to persist for the foreseeable future.

Domestic courts have advantages beyond their superior resources. They enjoy established procedures for litigation, as well as established powers to develop evidence and enforce judgments. Advantages also arise from the generalist nature of domestic courts' responsibilities. As much as they may strive for impartiality, a court whose raison d'etre is to prosecute particular defendants or crimes is likely to adopt a different perspective from one that sees humanrights cases as just another subject on its general docket. ${ }^{482}$ Likewise,

"defendants about whom the international community has broadly agreed that they may be prosecuted and punished, and whose state of nationality has not defended them"). The ICC, which has a more general mandate, is off to a rockier start. See, e.g., Rebecca Hamilton, Guest Post: When Should the ICC Call It Quits?, OPINIO JURIs, http://opiniojuris.org/2015/01/10/guestpost-icc-call-quits (Jan. 10, 2015, 10:14 AM) (describing the ICC's suspension of investigative activities in Darfur after its inability to enforce its arrest warrants); Turner, Accountability, supra note 471, at 1-2 (noting general concerns about the ICC's accountability). That tribunal may be most likely to succeed when it works in conjunction with national courts. See generally Jenia Iontcheva Turner, Nationalizing International Criminal Law, 41 STAN. J. INT'L L. 1 (2005) [hereinafter Turner, Nationalizing].

479. See ALTER, supra note 327, at 335.

480. See, e.g., Karen Alter, Remarks at Duke Law School (Apr. 15, 2014) (acknowledging this point); International Criminal Court, Understanding the International Criminal Court, http://www.icc-cpi.int/iccdocs/PIDS/publications/UICCEng.pdf (last visited Feb. 4, 2015) ("The International Criminal Court is not a substitute for national courts."); CTR. FOR JUSTICE \& AcCountability, The Alien Tort Statute: A Means of Redress for Survivors of Human Rights Abuses, available at http://www.cja.org/article.php?id=435 (last visited Feb. 4, 2015) (agreeing that "human rights law-if it is to be effective-must be implemented on a national level, through domestic courts"); Akhavan, supra note 477, at 1251 (observing that "the entire complementarity scheme [of the ICC] rests on the fundamental assumption that national prosecutions are essential to the viability of the international criminal justice system"); Turner, Nationalizing, supra note 478, at 1-2 ("A less hierarchical international criminal justice system that relies significantly on national governments is likely to be better informed by diverse perspectives, more acceptable to local populations, and more effective in accomplishing its ultimate goals."); MARY ANN GLENDON, A WORLD MADE NEW: ELEANOR ROOSEVELT AND THE UNIVERSAL DECLARATION OF HUMAN RIGHTS 237 (2001) ("[T]he fact is that international institutions can never provide first-line protection for victims of rights violations. When protection at the national level is absent or breaks down, there are severe limitations to what international enforcement mechanisms can accomplish.”).

481. See supra notes 38-41 and accompanying text.

482. Cf. Morrison v. Olson, 487 U.S. 654, 727-32 (1988) (Scalia, J., dissenting) (criticizing the domestic independent counsel mechanism on similar grounds). 
the frustrating abstraction of international human-rights discourse may be tempered by the likely cross-fertilization arising from deciding international cases alongside garden-variety domestic torts, crimes, and discrimination claims.

The key point, however, is that courts function most effectively when they are embedded within a larger legal system. ${ }^{483}$ This embeddedness broadens the court's legitimacy, enhances its access to resources, provides executive aid to enforce its decisions, and permits legislative adjustment of the governing law in reaction to the court's activity. ${ }^{484}$ Proponents of international adjudication typically worry about domestic courts' dependence on national governments, but that dependence will often run both ways. Critically, national governments and private entities depend on their domestic courts for a wide range of functions-especially the prosecution of domestic crimes, the resolution of private disputes, and the accommodation of local practices to national law. Barry Friedman and Erin Delaney have demonstrated, for example, that the U.S. Supreme Court developed a strong role of reviewing the constitutionality of national legislation and enforcing individual rights in part because the national government depended on that court to bring state governments in line with national law. ${ }^{485}$ The broader point is that because national courts depend on domestic courts as instruments of state power, they generally cannot afford to undermine those courts by defying their rulings on human-rights questions. ${ }^{486}$ The costs of defying freestanding human-rights tribunals at the international level are considerably less. The U.S. government has been known to defy the ICJ, for example; ${ }^{487}$

483. See POSNER, supra note 40, at 164.

484. Consider, for example, Congress's expansion of statutory rights and enforcement mechanisms to combat systematic racial discrimination in the United States, in reaction to the course of the Supreme Court's case law on that subject.

485. See Barry Friedman \& Erin F. Delaney, Becoming Supreme: The Federal Foundation of Judicial Supremacy, 111 ColuM. L. REV. 1137, 1140 (2011); see also Erin F. Delaney, Judiciary Rising: Constitutional Change in the United Kingdom, 108 Nw. U. L. REV. 543 (2014) (arguing that the British judiciary is likely to become more powerful generally vis-à-vis the government based on its acquisition of responsibility to enforce the rules of devolved power in the U.K.).

486. Cf. JAMES T. PATTERSON, GRAnd EXPECTATIONS: The United STATES, 1945-1974, at 414-15 (1996) (describing how President Eisenhower had to support the Supreme Court in the Little Rock desegregation crisis in order to squelch Southern defiance of federal law).

487. See U.S. Terminates Acceptance of ICJ Compulsory Jurisdiction, 1986 DEP'T STATE BULL. 67, 68 (noting that "[o]ur experience in the case instituted against the United States by Nicaragua in April, 1984 provided the chief motivation for the Administration's review of our acceptance of the Court's compulsory jurisdiction"); Andreas L. Pauls, From Neglect to 
it is much harder to imagine U.S. government officials defying an order from a domestic federal court. ${ }^{488}$

The two European courts demonstrate the same point. By far the most successful supranational courts are the European Court of Human Rights (ECtHR) and the European Court of Justice (ECJ) ${ }^{489}$ And yet these courts are both embedded within communities of European states bound together by a much thicker set of rules and institutions than international society at large. The ECJ is a coordinate branch of a full-fledged government for the European Union (EU).$^{490}$ Its human-rights jurisprudence has evolved, at least in part, as a means of furthering the supremacy and integrative function of European law. ${ }^{491}$ Much as in the United States, EU officials can defy the ECJ's human-rights rulings only at the risk of undermining the Court's power to check the Member States. ${ }^{492}$

The ECtHR, on the other hand, is formally autonomous and covers considerably more states than the EU. But the ECtHR's overlap with and connection to the EU legal order probably explains much of its influence. The ECtHR is now formally integrated into EU law in a number of characteristically convoluted ways, ${ }^{493}$ and the ECJ

Defiance? The United States and International Adjudication, 15 EUR. J. INT'L L. 783, 788 (2004) (discussing the United States' refusal to accept the ICJ's judgment in the Nicaragua case).

488. Cf. United States v. Nixon, 418 U.S. 683 (1974) (successfully ordering the President to hand over evidence of criminal wrongdoing by the President and his staff).

489. See ALTER, supra note 327, at 103 (showing that "the extent of activity and influence of [the ECJ and the ECtHR] can make all other [international courts] pale in comparison"); Elizabeth F. Defeis, Human Rights and the European Court of Justice: An Appraisal, 31 FORDHAM INT'L L.J. 1104, 1112 (2008) (observing that it “is undisputed . . . that the ECJ has played a central role in shaping the human rights discourse and the treaties that now incorporate human rights protection"). But see POSNER, supra note 40, at 158-59 (questioning assertions of broad compliance with ECtHR rulings).

490. See PoSNER, supra note 40, at 161 (suggesting that "the reason for its success is that the ECJ is not truly an 'international court' for purposes of comparison with the ICJ, arbitral tribunals, and other courts").

491. See Joseph H.H. Weiler, Eurocracy and Distrust: Some Questions Concerning the Role of the European Court of Justice in the Protection of Fundamental Rights Within the Legal Order of the European Communities, 61 WASH. L. REV. 1103, 1118-19 (1986).

492. Cf. Friedman \& Delaney, supra note 485, at 1152-59.

493. See Sionaidh Douglas-Scott, The European Union and Human Rights after the Treaty of Lisbon, 11 HUM. RTS. L. REV. 645, 650-51, 655 (2011) (explaining that the Lisbon Treaty, which came into force in 2009, gave binding legal force to the EU Charter of Fundamental Rights, which in turn provides for parity of interpretation of those rights overlapping with the ECtHR; the treaty also initiated the process of EU accession to the ECtHR itself); Tommaso Pavone, The Past and Future Relationship of the European Court of Justice and the European Court of Human Rights: A Functional Analysis 3 (May 28, 2012) (unpublished manuscript) 
has for many years looked to the European Convention on Human Rights and the ECtHR's decisions interpreting it. ${ }^{494}$ And as one might expect, the comparative autonomy of the ECtHR comes at a cost in efficacy. That court has more limited remedial authority than the ECJ, and its jurisprudence incorporates a great deal of substantive deference to national governments. ${ }^{495}$ The two most successful international courts thus demonstrate the importance of embeddedness in a domestic legal regime.

Domestic experience with public-law litigation likewise illustrates the importance of situating judicial review within a fullblown domestic legal system. Brown v. Board of Education ${ }^{496}$ is the American paradigm of public-law litigation, yet the post-Brown history of desegregation efforts demonstrates that courts are most successful in combating entrenched and extensive human-rights violations when they act in conjunction with executive and legislative institutions. ${ }^{497}$ Much of Brown's impact on the history of civil rights, moreover, stems from the symbolic force of the Supreme Court's declaration that segregation violated the supreme law of the land. ${ }^{498}$ That impact may well be less when the pronouncement comes from outside the national legal system.

As with much public-law litigation, moreover, the critical remedial element for desegregation was not damages but injunctive relief; desegregation of public schools required extensive judicial

(http://ssrn.com/abstract=2042867) ("[T]hrough the 2009 Lisbon Treaty the EU member states took action to unify the [EU and ECtHR human rights] regimes.").

494. See Defeis, supra note 489, at 1113-14 ("In recent years, the ECJ has effectively incorporated not only the provisions of the ECHR, but also the decisions of the [ECtHR] into its human rights jurisprudence."); Weiler, supra note 491, at 1135 ("The [ECJ] has indicated its intention to look to the ECHR whenever an issue of human rights comes before it.").

495. See Andreas Follesdal, The Legitimacy of International Human Rights Review: The Case of the European Court of Human Rights, 40 J. Soc. PHIL. 595, 595 (2009) (observing that the ECtHR exercises a "weak" form of judicial review in that "the ECtHR can find a law or its application to be incompatible with the ECHR, but this does not directly affect the validity of that law in the domestic legal system"); Pavone, supra note 493, at 10-11 (noting that the ECtHR may only impose fines on a violating state, and that its doctrine incorporates both a "margin of appreciation" protecting the discretion of national governments and a measure of deference to majoritarian state practices).

496. Brown v. Bd. of Educ., 347 U.S. 483 (1954).

497. See generally Gerald N. Rosenberg, The Hollow Hope: CAN COURTS Bring About Social ChANGE? (1993) (demonstrating that judicial action is most effective when combined with action by the political branches).

498. See, e.g., David Garrow, Hopelessly Hollow History: Revisionist Devaluing of Brown v. Board of Education, 80 VA. L. REV. 151, 152-53 (1994) (presenting evidence that Brown inspired the efforts of civil-rights protesters involved in the Montgomery bus boycott). 
supervision of public institutions, often lasting for many decades. ${ }^{499}$ No foreign or supranational court can hope to provide this sort of relief, and ATS claimants have generally sought damages alone. Finally, much of the judicial impact in support of the AfricanAmerican civil-rights movement came not in the form of decisions mandating particular reforms, but rather through judicial holdings that shielded various forms of political protest and limited the oppressive power of the state criminal-justice system. ${ }^{500}$ Courts outside the domestic legal system are poorly situated to perform this role.

The considerations just discussed provide reasons not only to favor national courts per se, but also to employ them in particular roles. Brown and similar cases involve national courts engaged in review of actions by their own governments (or subnational governments). There are, of course, drawbacks to this degree of embeddedness. Even in countries with well-developed norms of judicial independence, courts called upon to enforce international law against their own governments "often defer to governments because the executive branch enjoys foreign affairs power, because governments have more insight into what an international agreement was supposed to mean, and because diplomats often have a better sense of how different legal interpretations might impact foreign relations. ${ }^{501}$ That sort of deference may often be salutary-a means of mitigating the countermajoritarian difficulty that courts otherwise face. ${ }^{502}$ But of course the primary drawback to relying on national courts to review acts by or associated with their own governments is that judicial review will often be unavailable or corrupt in the country in which the rights violations occurred. ${ }^{503}$

499. See, e.g., Swann v. Charlotte-Mecklenburg Bd. of Educ., 402 U.S. 1, 16 (1971) (affirming the courts' "broad power to fashion [an equitable] remedy that will assure a unitary school system"); Freeman v. Pitts, 503 U.S. 467 (1991) (ruling on a request to withdraw district court supervision of a desegregation plan for a Georgia school district first imposed in 1969).

500. See, e.g., N.Y. Times Co. v. Sullivan, 376 U.S. 254 (1964) (relying on the Free Speech Clause of the First Amendment to prevent use of libel litigation to deter coverage of the civilrights movement by news organizations); Garner v. Louisiana, 368 U.S. 157 (1961) (overturning convictions of civil-rights protesters involved in lunch-counter sit-ins on due-process grounds); see also Ernest A. Young, Constitutionalism Outside the Courts, in OXFORD HANDBOOK ON THE CONSTITUTION (Mark Graber, Sanford Levinson \& Mark Tushnet eds., forthcoming 2015), available at $\mathrm{http}: / /$ papers.ssrn.com/sol3/papers.cfm?abstract_id=2551025.

501. ALTER, supra note 327, at 9.

502. See BICKEL, supra note 463, at 16-23.

503. See, e.g., Philippe Kirsch, The Role of the International Criminal Court in Enforcing International Criminal Law, 22 AM. U. INT'L L. REV. 539, 540 (2007). 
By contrast, transnational public-law cases typically ask national courts to entertain challenges to practices by foreign governments and officials or private entities acting in concert with them. Universal jurisdiction is the pure type, but courts exercising jurisdiction over actions and parties with little nexus to the forum state will have few of the advantages that national courts ordinarily derive from embeddedness within a robust domestic legal system. Consider a hypothetical effort by a Belgian court in the late 1950s to exercise universal jurisdiction over Orval Faubus, the segregationist governor of Arkansas who sought to block desegregation of the Little Rock schools. ${ }^{504}$ Such a suit would surely have aroused considerable resentment in the United States; it might even have brought Governor Faubus sympathy as the target of "outside agitators."

Equally important, the Belgian court's remedial toolkit would have been extremely limited. The most promising option would have been a damage award against some multinational company implicated in Arkansas' segregated regime - an American manufacturer of Little Rock's school buses possessing European assets, perhaps-but no foreign court would have been able to undertake the sort of continuing oversight that desegregation litigation turned out to require. Most important, the domestic political branches would have been extremely unlikely to make their own efforts to support the Belgian court's orders politically, supervise compliance with its rulings, or enact complementary legislation. Proponents of ATS litigation in foreign-cubed cases have rightly touted the symbolic benefits of judicial rulings vindicating plaintiffs' human-rights claims, but few would argue that such cases can force meaningful reform.

The second wave of Filártiga suits may be an intermediate case, to the extent they are directed at American corporations and behavior with a significant nexus to the United States. That nexus enhances the legitimacy of national court intervention; it also brings the defendants' conduct within reach of a broader range of remedial tools. One could imagine, for example, consent decrees that would require a corporate defendant to institute controls over cooperation with foreign security forces; such a decree might well involve continuing judicial supervision over compliance. Likewise, it is far more realistic to expect complementary legislation and executive action bearing on action by American defendants or conducted within

504. For an account, see Tony A. Freyer, Politics and Law in the Little Rock Crisis, 19541957, 66 ARK. HIST. Q. 145 (2007). 
the United States. It remains to be seen, of course, whether the basic model of second-wave Filártiga cases can truly work; even if courts impose large damages awards on corporate defendants implicated in human-rights abuses abroad, those defendants may turn out to have insufficient leverage to effect real change in foreign countries. ${ }^{505}$

Given such uncertainties, we should temper expectations for transnational public-law litigation in the Filártiga mold. Notwithstanding the impressive accomplishments of public-law litigation within the domestic sphere, American judicial power will be hard to exercise to similar effect across international borders. Even if our courts can exercise only limited leverage over the behavior of foreign human-rights abusers, however, ATS litigation in domestic courts may serve three more modest purposes. First, successful suits against corporate aiders and abettors may compensate victims even if they do not force reform in the victims' home countries. A second purpose dovetails with the First Congress's likely intent that American courts provide a remedy for violations of the law of nations perpetrated within the United States or by Americans abroad. ${ }^{506}$ That is not quite the "badge of honor" that Anne-Marie Slaughter had in mind for the ATS, but it is nonetheless part of good international citizenship.

The third purpose ought to appeal to both proponents and traditional critics of ATS litigation. Human-rights cases in national courts offer those courts an opportunity to help shape and articulate norms of international law, rather than leaving those norms to supranational and foreign courts. Generally speaking, the American debate has seen internationalists pressing for the recognition of international human-rights claims in domestic courts, while

505. Other problems may arise from the possibility that multiple jurisdictions may assert authority to adjudicate any given rights claim. One can imagine, for example, an international version of the infamous "Delaware settlement" in federal securities law, under which litigation occurs in a friendly jurisdiction and results in a lenient settlement, which is then asserted to preclude litigation in other more rigorous jurisdictions. See, e.g., Matsushita Elec. Indus. Co. v. Epstein, 516 U.S. 367, 388-99 (1996) (Ginsburg, J., concurring in part and dissenting in part) (noting this problem). Russia might purport to try Syrian war criminals, imposing light penalties and then asserting that its judgment bars prosecution in any other jurisdiction. But there is no reason the international law of conflicts and judgments cannot develop rules to address such problems. Moreover, overlapping jurisdictions are a feature as well as a bug, because they provide a check on any one nation's unwillingness to prosecute a given claim.

506. See Bellia \& Clark, Law of Nations, supra note 115, at 448-49; Lee, Safe Conduct, supra note 117 , at 836-38. 
nationalists have resisted that effort. ${ }^{507}$ But nationalists ought to rethink that position. International human-rights law is unlikely to go away, and it is more likely to develop in ways that are insensitive or inimical to American interests if our own courts do not participate in that development. ${ }^{508}$ Conversely, American jurists deciding humanrights cases are likely to exert considerable influence, given the prestige of the American judiciary, its robust practice of reasongiving, and the ready accessibility of its opinions. The best way to make international human-rights law more compatible with American foreign and security policy is to make our courts active participants in that law's formation.

2. Public vs. Private Enforcement. I have already discussed some of the concerns about private enforcement-in particular, that it places the decision to initiate human-rights litigation in the hands of persons with no particular mandate (and insufficient information) to reconcile that litigation with their nation's broader foreign policy. Analogous concerns exist at the domestic level. American law allows extremely broad scope for private litigation that coexists, often uneasily, with public regulatory schemes. Sometimes both public and private enforcement exist for the same statutory standards. The federal employment-discrimination laws, for example, are enforced through both public actions by the Equal Employment Opportunity Commission and private suits by victims of discrimination; ${ }^{509}$ likewise, federal statutes restricting securities fraud have been construed to permit both public actions by the SEC and private suits by shareholders. ${ }^{510}$ In other areas, private litigation under state common law occurs alongside public administration and enforcement. The federal Food and Drug Administration (FDA) approves the sale of prescription drugs, for example, but private plaintiffs injured by a defective drug may bring a state tort suit against the manufacturer. ${ }^{51}$

Not surprisingly, a vigorous domestic debate addresses the desirability of private enforcement. ${ }^{512}$ Critics of private tort litigation

507. See, e.g., Childress, supra note 6, at 710-11.

508. See Young, Institutional Settlement, supra note 231, at 1221-29 (developing this argument).

509. See 42 U.S.C. § 2000e-5(f) (2012).

510. See supra notes $241-44$ and accompanying text.

511. See, e.g., Wyeth v. Levine, 555 U.S. 555, 580-81 (2009).

512. See, e.g., Federal PreEmption: States' Powers, National Interests (Richard A. Epstein \& Michael S. Greve eds., 2007) [hereinafter EPSTEIN \& GREVE]; THOMAS O. 
over defective drugs, for example, argue that such litigation undermines the FDA's role as regulator and chills the development and marketing of new medicines. ${ }^{513}$ In many areas, such as medical devices and generic drugs, Congress has protected the primacy of public enforcement by preempting private litigation $;{ }^{514}$ in others, both Congress and the courts have recognized that private enforcement plays a valuable supplementary role. ${ }^{515}$ The Supreme Court has thus steered a middle course dictated largely by the details of particular statutory regimes rather than broad preferences for or against private enforcement. $^{516}$

The ATS debate in many ways fits comfortably within this frame. Critics of the Filártiga line would rely on Congress and the Executive to set standards for human-rights violations and to determine when, if ever, enforcement actions under those standards should be brought in American courts. ${ }^{517}$ Advocates, on the other hand, would likely respond that Congress suffers from political gridlock and a crowded agenda, and in any event it cannot draft legislation with sufficient flexibility to accommodate the evolving imperatives of international human rights. ${ }^{518}$ Likewise, the national Executive has traditionally monitored and reported on human-rights violations abroad but has shown little inclination to pursue foreign rights violators in American courts. ${ }^{519}$

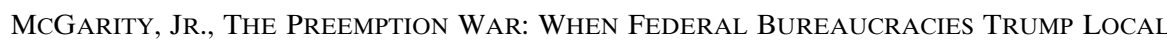
JURIES (2008).

513. See, e.g., Daniel E. Troy, The Case for FDA Preemption, in EPSTEIN \& GREVE, supra note 512 , at $81,100-05$.

514. See, e.g., PLIVA, Inc. v. Mensing, 131 S. Ct. 2567, 2581 (2011); Riegel v. Medtronic, Inc., 552 U.S. 312, 321-30 (2008).

515. See, e.g., Wyeth, 555 U.S. at 581 (rejecting preemptive effect for FDA approval of a brand-name drug's label).

516. See generally Ernest A. Young, "The Ordinary Diet of the Law": The Presumption Against Preemption in the Roberts Court, 2011 SuP. CT. REV. 253, 302-06 (2012) (surveying the Court's preemption cases).

517. See, e.g., Bradley \& Goldsmith, Current Illegitimacy, supra note 167, at 356.

518. See, e.g., Koh, State Law, supra note 165, at 1843-45, 1854 (observing that the legislative process is "notoriously dominated by committees, strongwilled individuals, collective action problems, and private rent-seeking" and suggesting that Congress should more appropriately play a reactive role by incorporating norms of CIL in federal statutes after they have evolved through judicial recognition); see also Jonathan Serrie, Gridlock in Congress Stalls Human-Trafficking Bill, FOX NEWS (Oct. 2, 2012), http://www.foxnews.com/ politics/2012/10/02/gridlock-in-congress-over-human-trafficking (last visited Feb. 4, 2015).

519. See U.S. DeP'T OF STATE, Country Reports on Human Rights Practices for 2013, http://www.state.gov/j/drl/rls/hrrpt/humanrightsreport/index.htm\#wrapper (last visited Feb. 4, 2015). 
It ought to help simply to recognize the similarity between the debates in foreign-relations law and domestic regulatory policy. As exotic as cases like Filártiga or Kiobel may seem, the issues they raise are hardly sui generis. The advantages of public and private enforcement are familiar from the domestic debate: Public enforcement is good for setting uniform standards and for integrating those standards with other aspects of legislative and executive policy. Public enforcement is likewise subject to majoritarian political checks on both over- and underenforcement of public norms. Private enforcement, on the other hand, leverages private resources to make up for constraints on public-enforcement funding. It may provide better back-end monitoring of harms (as opposed to front-end standard setting). And it frequently provides compensation for victims that is lacking in public-enforcement schemes.

Few areas of domestic law rely exclusively on public enforcement, and a reliance on private enforcement is an integral part of American litigation culture. ${ }^{520}$ If we take seriously an internationallaw obligation to address human-rights violations, at least when those violations have some connection to the United States, then we should think twice before either gutting the ATS or adopting an untrammeled regime of private enforcement. Moreover, the case for exclusive public enforcement in the domestic context typically relies on Congress's delegation of authority to an expert agency that sets standards and, to at least some extent, monitors compliance. ${ }^{521}$ There is no such federal agency charged in this way with enforcement of human rights. The State Department monitors human-rights abuses, but its primary role is to conduct diplomacy. It might well undermine the Department's diplomatic role to expect it to take a position on every alleged human-rights abuse; for this reason, some degree of institutional separation between human-rights enforcement and diplomacy may actually further the Executive's ability to conduct foreign policy. ${ }^{522}$

520. See supra notes 416-20 and accompanying text.

521. See, e.g., Troy, supra note 513, at 103-104 (emphasizing the role of the FDA).

522. In the mid-twentieth century, federal courts deciding cases involving foreign sovereign immunity routinely deferred to the State Department's position as to whether a nation should be accorded immunity in the circumstances of that case. Both Congress and the Executive ultimately considered this so-called "Tate Letter" regime detrimental to American foreign policy, because it pressured the State Department to take a position on immunity whenever a foreign nation requested it to do so-even when the Department preferred to remain silent. Congress enacted the FSIA in part to allow courts to decide foreign immunity issues independently of the Executive. See generally BRADLEY \& GOLDSMITH, supra note 395, at 74- 
Notwithstanding the ubiquity of private attorneys general, our domestic law typically subjects private enforcement to important limits. Courts have not hesitated to find preemption where private tort suits interfere with federal regulatory policy, and the Supreme Court has been increasingly cautious about inferring private rights to sue where Congress has not made its intent clear. And ever since President Washington's Neutrality Proclamation in $1793,{ }^{523}$ American law has asserted a particular concern with maintaining public control over foreign policy. Kiobel's presumption against extraterritoriality seems likely to weed out the cases most likely to threaten that control. Where ATS claims do have a significant nexus to the United States, the benefits of leveraging private litigation resources and providing compensation for victims suggest a continuing role for private enforcement.

$$
* * *
$$

At the end of the day, these judgments about the role of national courts and private enforcement are ones that Congress ought to make. Scholars writing about the ATS have worked hard to milk every ounce of meaning out of a terse statutory text and a sparse historical record. But at some point, we should recognize that the drafters of the ATS neither anticipated nor provided answers to the questions posed by contemporary human-rights litigation. As AnneMarie Slaughter has acknowledged, the drafters of the first Judiciary Act "could not have anticipated a case like Filártiga." ${ }^{524}$ It would be surprising, then, to discover in the historical materials answers to questions about aiding-and-abetting liability or an exhaustion requirement. It would be even more surprising if those answers suited the international situation of the contemporary United States. As Tom Lee has emphasized, the foreign-policy and security imperatives of a small, weak, and geographically isolated nation were rather

75. This episode suggests there are advantages to letting the Executive deny responsibility for judicial determinations.

523. See id. at 12-26 (discussing this episode). Likewise, the Logan Act makes it a federal crime for private citizens to conduct foreign diplomacy. See Logan Act, 1 Stat. 613 (1799) (codified as amended at 18 U.S.C. $\$ 953$ (2012)). But see Confrontation in the Gulf; Jesse Jackson Meets Hussein on Gulf Crisis, Iraq Reports, N.Y. TIMES, Aug. 31, 1990, http://www .nytimes.com/1990/08/31/world/confrontation-gulf-jesse-jackson-meets-hussein-gulf-crisis-iraqreports.html.

524. Burley, supra note 7, at 488; accord HUFBAUER \& MITROKOSTAS, supra note 10, at 55. 
different from those of today's continental superpower with three hundred million people and vital interests all over the globe. ${ }^{525}$

If Congress declines to act, however, the courts will need to fill in the interstices of the ATS through federal common lawmaking. ${ }^{526}$ Sosa recognized that ATS cases rely on a federal cause of action implied as a matter of federal common law, ${ }^{527}$ and courts have been willing to construct federal-common-law doctrine as needed to fill in the procedural and remedial details for other implied rights of action under the federal securities laws and other statutes. ${ }^{528}$ Both the Court's ATS decisions in Sosa and Kiobel and its implied-rights cases generally suggest that the Court will fill gaps conservatively-that is, that it will continue to view the appropriate scope of ATS litigation more narrowly than some lower courts and the human-rights bar might like, but also that it will preserve the Founders' basic notion of a private federal remedy for violations of the law of nations. However one might hope for a more original insight at the end of a long article, that approach strikes this author as fundamentally sound.

\section{CONCLUSION}

As Ingrid Wuerth rightly observes, the "real difficulty" with the debate about the ATS is that "[b]oth sides of the debate capture important and deeply-held values"-on the one hand, "redress for horrific violations of the most fundamental human rights"; but on the other, "the basic sense that many of these cases have very little to do with the United States, may impose foreign policy costs, and may not enhance net social welfare for those most harmed." ${ }^{529}$ Often these values are presented through high-stakes rhetoric: Beth Stephens hails the ATS as "a means to hold the most egregious perpetrators accountable for the most egregious violations of international law, and a pre-Kiobel statement by EarthRights International predicted

525. See generally Thomas H. Lee, Theorizing the Foreign Affairs Constitution (Fordham Univ. Sch. of Law Legal Studies Research Paper Series, Working Paper No. 1996734, Jan. 31, 2012), available at http://papers.ssrn.com/sol3/papers.cfm?abstract_id=1996734.

526. See generally D’Oench, Duhme \& Co. v. FDIC, 315 U.S. 447, 467-73 (1942) (Jackson, J., concurring) (discussing the need for courts to fill statutory gaps with federal common law).

527. Sosa v. Alvarez-Machain, 542 U.S. 692, 724 (2004).

528. See, e.g., Musick, Peeler \& Garrett v. Emp'rs Ins. of Wausau, 508 U.S. 286, 297-98 (1993) (fashioning a federal-common-law right of contribution in suits under $\S 10$ (b) of the Securities Exchange Act of 1934 and Securities and Exchange Commission Rule 10b-5).

529. Wuerth, supra note 4, at 620.

530. Stephens, Sosa, supra note 204, at 535. 
that "human rights law [would] be set back decades" if the defendants prevailed in that case. ${ }^{531}$ Similarly, a prominent study criticizing the ATS posed a "nightmare scenario" in which "100,000 class action Chinese plaintiffs, organized by New York trial lawyers," file suit against major multinational corporations like General Motors, Toyota, and Siemens in federal court "for abetting China's denial of political rights, for observing China's restrictions on trade unions, and for impairing the Chinese environment. These plaintiffs might claim actual damages of $\$ 6$ billion and punitive damages of $\$ 20$ billion." ${ }^{532}$ Such a suit, and the settlement pressures it would engender, might massively "chill...trade and investment" and place the United States "at loggerheads with traditional allies, trading partners, and developing countries." ${ }^{533}$

As a legal academic, one always hates to argue that the law is less exciting than people think. But one implication of my exploration of ATS litigation is that the stakes may not be as high as they sometimes seem. The "most egregious perpetrators" of human-rights abuses are unlikely to find themselves in the ATS dock, and-as Professor Stephens acknowledges - the ATS is unlikely to "plac[e] the federal courts at the cutting edge of the progressive development of international human rights norms. ${ }^{, 534}$ Nor is the business community's "nightmare scenario" likely to come to pass: no large damages awards have been rendered against corporate defendants; settlements have been relatively modest; and massive class actions remain largely on the horizon. Likewise, the federal courts' efforts to narrow the ATS, including the Supreme Court's decision in Kiobel, are unlikely to usher in a new era of expanded impunity. The courts' limits have limits, and other avenues-including the TVPA and state litigationremain. It is, perhaps, time to step back and take a breath.

531. The U.S. Supreme Court Must Preserve the Alien Tort Statute for International Corporate Human Rights Cases, EARTHRIGHTS INT'L (June 13, 2012), http://www.earth rights.org/legal/us-supreme-court-must-preserve-alien-tort-statute-international-corporatehuman-rights-cases; see also Tyler Giannini \& Susan Farbstein, Corporate Accountability in Conflict Zones: How Kiobel Undermines the Nuremberg Legacy and Modern Human Rights, 52 HARV. INT'L L.J. ONLINE 119, 132 (2010), available at http://www.harvardilj.org/wpcontent/uploads/2010/11/HILJ-Online_52_Giannini_Farbstein.pdf (suggesting that the Second Circuit's exclusion of corporate liability in Kiobel "would have permitted the German state to privatize the gas chambers with the result that a company like I.G. Farben would then have been able to exterminate millions of people for profit with impunity").

532. HUFBAUER \& MitrokOSTAS, supra note 10, at 1.

533. Id. at 1-2.

534. Stephens, Sosa, supra note 204, at 535. 
In this Article, I have argued that the tension between the competing values implicated by ATS litigation should not be resolved based on sui generis doctrines of foreign-relations law, but rather in two more traditional ways. The first is to fit the problems arising under the ATS into traditional federal-courts doctrines governing implied rights of action. The second is to apply those doctrines using data to be gleaned from foreign experiences with the actual exercise of universal jurisdiction. These approaches, however, can only take us so far. Where they run out, we should not assume that judicial lawmaking can answer every question. It may be that only Congress can construct an appropriately nuanced and workable regime for private human-rights litigation.

Any decisionmakers addressing the ATS after Kiobel should consider its unresolved issues in light of broader debates about the structure of human-rights enforcement in international law. Humanrights enforcement should not be left to supranational institutions, both because they lack the resources and legitimacy to do an adequate job and because the development of international humanrights law would benefit from the participation of American courts. In assessing the way domestic institutions enforce human rights, moreover, we should consider another broader debate-that involving the proper balance between public and private enforcement at the domestic level. Domestic experience suggests that a mix of public and private enforcement is best, and one may hope that the Supreme Court remains committed to this sort of balance.

International human-rights law has largely succeeded in establishing a core of widely accepted prohibitions on torture, genocide, and similar acts. The challenge now is designing institutions to vindicate those principles. Because sovereign states continue to dominate the international scene, these institutions will have to be built primarily at the domestic level. And they are more likely to endure if they accommodate both the moral imperatives of humanrights law and individual nations' needs to maintain security and pursue other national interests. The complexities and compromises that this will entail are, after all, part of what it means to treat international law as law. 